(x)
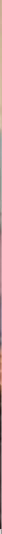

$\log ^{7} \frac{4}{1-5}$

\title{
Biodiversity and Local Perceptions on the Edge of a Conservation Area, Khe Tran Village, Vietnam
}

Manuel Boissière • Imam Basuki • Piia Koponen Meilinda Wan • Douglas Sheil

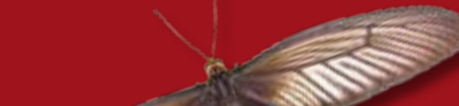
15: 
National Library of Indonesia Cataloging-in-Publication Data

Boissière, Manuel

Biodiversity and local perceptions on the edge of a conservation area, Khe Tran village, Vietnam/ by Manuel Boissière, Imam Basuki, Piia Koponen, Meilinda Wan, Douglas Sheil. Bogor, Indonesia: Center for International Forestry Research (CIFOR), 2006.

ISBN 979-24-4642-7

$106 \mathrm{p}$.

CABI thesaurus: 1. nature reserve 2. nature conservation

3. landscape 4 . biodiversity 5 . assessment 6 . community involvement

7. Vietnam I. Title

(C) 2006 by CIFOR

All rights reserved.

Printed by Inti Prima Karya, Jakarta

Revised edition, June 2006

Design and layout by Catur Wahyu and Gideon Suharyanto

Photos by Manuel Boissière and Imam Basuki

Maps by Mohammad Agus Salim

Cover photos, from left to right:

- A villager prepares the soil for peanut plantation in a former rice field, Khe Tran

- A young woman carries Acacia seedling ready to be planted

- Villagers discuss the future of Phong Dien Nature Reserve

- The different land types in Khe Tran: bare land, village with home gardens, rice fields, and protected mountain areas

Published by

Center for International Forestry Research

JI. CIFOR, Situ Gede, Sindang Barang

Bogor Barat 16680, Indonesia

Tel.: +62 (251) 622622; Fax: +62 (251) 622100

E-mail: cifor@cgiar.org

Web site: http://www.cifor.cgiar.org 


\section{Contents}

Acronyms and terms vii

Acknowledgements ix

1. Research context and objectives 1

2. Methods 3

Village activities 3

Field activities $\quad 4$

3. Achievements 8

4. Conservation context in Khe Tran 10

4.1. Previous conservation activities 10

4.2. Government programs that affected Khe Tran village 12

$\begin{array}{ll}\text { Summary } & 14\end{array}$

5. Site description 15

5.1. Research site $\quad 15$

5.2. People from Khe Tran 17

5.3. Land use and natural resources 23

Summary 28

6. Local perceptions of the different land types and resources 29

6.1. Local land uses 29

6.2. Land type importance 31

6.3. Forest importance 32

6.4. Forest importance in the past, present and future 34

6.5. Importance according to source of products 36

6.6. Most important products from the forest 37

6.7. Threats to local forests and biodiversity 41

6.8. People's hopes for the future of their forest and life 42

Summary 45 
7. Characterization of land types 46

7.1. Sampling of land types 46

7.2. Specimen collection and identification 48

7.3. Plant biodiversity 51

7.4. Forest structure 53

7.5. Species vulnerability 55

Summary $\quad 58$

8. Ethno-botanical knowledge $\quad 59$

8.1. Plant uses $\quad 59$

8.2. Species with multiple uses 61

8.3. Uses of trees 62

8.4. Uses of non-trees 62

8.5. Forest as resource of useful plants 64

8.6. Nonsubstitutable species 65

8.7. Remarks on potential uses of species 66

$\begin{array}{ll}\text { Summary } & 66\end{array}$

9. Local perspectives on conservation $\quad 67$

$\begin{array}{ll}\text { Summary } & 70\end{array}$

10. Conclusion and recommendations $\quad 71$

$\begin{array}{ll}\text { 10.1. Conclusion } & 71\end{array}$

10.2. Recommendations $\quad 75$

$\begin{array}{ll}\text { Bibliography } & 77\end{array}$

$\begin{array}{ll}\text { Annexes } & 79\end{array}$

1. LUVI (mean value) of important plant species by different use categories (result based on scoring exercise of four groups of informant) $\quad 79$

2. LUVI (mean value) of important animal species by different use categories based on scoring exercise of four groups of informant

3. The botanical names, families and local name of specimens collected within and outside the plots by their use categories 


\section{Tables and figures}

\section{Tables}

1. Composition of MLA research team in Khe Tran village 3

2. Important events affecting the local livelihoods 21

3. Income range by source of products and settlement area 22

4. Identified land types in Khe Tran 24

5. Regrouped land types in Khe Tran 25

6. Important forest plants and their local uses 30

7. Main categories of use of plant and animal resources 30

8. Local importance of land types by use category (all groups) 33

9. Forest importance by use categories (all groups) 33

10. Forest importance over time according to different use categories $\begin{array}{ll}\text { (all groups) } & 35\end{array}$

11. Importance (\%) of source of product by gender 37

12. Most important forest plants and animals in Khe Tran (all groups) 39

13. Most important forest plants by categories of use (all groups) 40

14. Most important forest animals by categories of use (all groups) 40

15. Locally important plant species by use category and IUCN list $\begin{array}{ll}\text { of threatened trees } & 41\end{array}$

16. Villagers' perception on threats to forest and biodiversity (19 respondents) 42

17. Villagers' perception about forest loss (19 respondents) 43

18. Villagers' ideas on threats to human life (19 respondents) 43

19. Summary of specimen collection and identification of plant species from 11 sample sites $\quad 50$

20. Plant richness in Khe Tran 53

21. Main tree species based on basal area and density listed with their uses in Khe Tran

22. Richness (total number of species recorded per plot) of life forms of non-tree species in all land types in Khe Tran

23. Threatened species in Khe Tran based on vegetation inventories and PDM exercises

24. Summary of specimen collection and identification of plant species from 11 sample sites

25. Mean number of species and number of useful species recorded in each land type

26. Distribution of all useful plant species per plot and by use category 61

27. Plant species with at least four uses 62

28. Distribution of tree species considered useful per plot and per use category 63

29. Distribution of non-tree species considered useful per plot and per use category 64

30. Villager's perceptions on conservation and Phong Dien Nature Reserve 69 


\section{Figures}

1. Scoring exercise (PDM) with Khe Tran men group 5

2. Working on sample plot 6

3. Location of Khe Tran village in the buffer zone of Phong Dien Nature Reserve

4. Situation of Khe Tran village 18

5. Livestock and Acacia plantations are important in Khe Tran 20

6. A woman from the lower part of the village harvests rubber from her plantation

7. Considerable areas of bare land are used in Khe Tran for new Acacia plantation

8. Biodiversity and resource distribution map of Khe Tran 27

9. Land type by importance (all groups) 31

10. Importance of forest types (all groups) 32

11. Forest importance over time (all groups) 35

12. Source of product importance (all groups) 37

13. Importance of forest resources by use categories (all groups) 38

14. Recent flood on a bridge between Phong My and Khe Tran 44

15. Field sampling of land types in Khe Tran (total sample size 11 plots) 47

16. Distribution of sample plots in the research area 49

17. Accumulation of non-tree species with the increasing random order of subplots (each $20 \mathrm{~m}^{2}$ ) for various land types in Khe Tran

18. Relative dominance in primary and secondary forest plots in Khe Tran based on basal area

19. Forest structural characteristics in Khe Tran. Left panel: basal area and density; right panel: tree height, stem diameter and furcation index

20. All plant species considered useful by the Khe Tran villagers shown in use categories

21. Total number of all useful plant species per category in primary, secondary and plantation forests 


\section{Acronyms and terms}

asl above sea level

CBEE Community-Based Environmental Education

CIFOR Center for International Forestry Research

CIRAD Centre de coopération Internationale en Recherche Agronomique pour le Développement

dbh diameter at breast height

DPC District Peoples Committee

ETHZ Eidgenössische Technische Hochschule Zürich (Federal Institute of Technology in Zürich)

ETSP Extension and Training Support Project

FIPI Forestry Inventory and Planning Institute

FPD Forest Protection Department

GoV Government of Vietnam

HUAF Hue University of Agriculture and Forestry

IUCN International Union for Conservation of Nature and Natural Resources

Land type component of landscape that is covered by natural coverage or used for human activities

Land use component of landscape that is used for human activities

Landscape holistic and spatially explicit concept that is much more than the sum of its components e.g. terrain, soil, land type and use

Lowlands village area on the lower reaches of O Lau river 
viii | Acronyms and terms

LUVI Local User Value Index

MLA Multidisciplinary Landscape Assessment

NTFP Non-Timber Forest Product

PDM Pebble Distribution Method

PDNR Phong Dien Nature Reserve

PPC Province Peoples Committee

SDC Swiss Development Cooperation

SFE State Forest Enterprises

TBI-V Tropenbos International-Vietnam

Uplands village area on the upper reaches of O Lau river

USD US Dollar

Village group of households included in a commune (subdistrict level) but not recognised as a legal entity in Vietnam

VND Vietnamese Dong (USD 1 approximately equals to VND 15,700)

WWF World Wildlife Fund 


\section{Acknowledgements}

We would like to express our profound gratitude to individuals and institutions for their assistance in the course of undertaking this research. We wish to thank the representatives of the Government of Vietnam, the Provincial Peoples Committee (PPC) of Thua Thien Hue province, Peoples Committee of Phong Dien district and Phong My commune for their interest in our work.

Our appreciations are addressed to Tran Huu Nghi, Jinke van Dam, Tu Anh, Nguyen Thi Quynh Thu, from Tropenbos International Vietnam, for their cooperation and for their assistance in organising our surveys.

We were lucky to collaborate with all the MLA participants: Le Hien (Hue University of Agriculture and Forestry), Ha Thi Mung (Tay Nguyen University), Vu Van Can, Nguyen Van Luc (FIPI), Nguyen Quy Hanh and Tran Thi Anh Anh (Department of Foreign Affairs of Thua Thien Hue province), and Ho Thi Bich Hanh (Hue College of Economics) for their hard work and interest for the project.

We would like to thank Patrick Rossier (ETSP-Helvetas), Eero Helenius (Thua Thien Hue Rural Development Programme), and Chris Dickinson (Green Corridor Project-WWF), for their useful suggestions.

We wish to thank Ueli Mauderli (SDC), Jean Pierre Sorg (ETHZ), for their useful comments and suggestions during their survey in Khe Tran, Jean-Laurent Pfund and Allison Ford (CIFOR) for their valuable comments during the redaction of the report, Michel Arbonnier (CIRAD) for the revision of the plant list, Henning Pape-Santos, our copy-editor, and Wil de Jong, the coordinator of the project for his support.

Last but not the least, we would like to thank the villagers from Khe Tran, Son Qua and Thanh Tan for their cooperation during our different surveys, for their patience and for all the information they provided to us. 



\section{Research context and objectives}

Vietnam has been reforming its forest management in favour of household and local organization (Barney 2005). The government increasingly gives local people the right to manage the forests. Unfortunately, in this changing environment, recognition of local people's rights is still limited and local knowledge and perspectives are rarely taken into account by the state institutions implementing land titling and decentralization. The challenge is to better inform each stakeholder on the perspectives of people living in and near the forest on the natural resources and landscapes. Furthermore, clarification of the local capacity to manage forests is necessary for better informed decision making.

Stakeholder and biodiversity at the local level is a three-year collaboration between the Center for International Forestry Research (CIFOR) and the Swiss Development Cooperation (SDC). Tropenbos International-Vietnam (TBI-V) has been a very helpful collaborator for coordinating the project activities. The project goal is to contribute to the enhancement of the livelihoods of local forest dependent communities and sustainable forest management. The project aims to strengthen local capacity to plan and implement locally relevant forest landscape management as a mechanism to achieve those goals. It focuses on situations where decentralization has given local government more authority and responsibility for forests. The project fosters better engagement by local decision-makers that takes into consideration the needs and preferences of local people, especially the poor communities.

Multidisciplinary landscape assessment, or MLA, is a set of methods developed by CIFOR scientists to determine "what is important to local communities, in terms of landscape, environmental services, and resources'. The approach is rooted in social (anthropology, ethnobotany and socio-economics) as well as natural sciences (botany, ecology, geography and pedology); was tested and used in different countries (Bolivia, Cameroon, Gabon, Indonesia, Mozambique and Philippines). The methods are fully detailed in four languages: English, French, Indonesia and Spanish (Sheil et al. 2003; http://www.cifor.cgiar.org/mla/). 
MLA helps the project by providing information on the way local people articulate and document their knowledge of land and natural resources uses. Local knowledge is considered crucial information for the management of forest.

Finally, in this report we aim to provide information on the way the local community in Khe Tran (Phong My commune, Phong Dien district, Thua Thien Hue province) perceives and manages its environment, and we discuss the options it has to participate in future nature reserve management. 


\section{Methods}

The multidisciplinary approach of MLA gathers information on land use in village and field, and studies local perceptions on forest landscapes and resources as well as local priorities in terms of land management and which land types, resources and activities are important to local people. The MLA team, working in both village and field, was composed by scientists from different disciplines (Table 1).

Table 1. Composition of MLA research team in Khe Tran village

\begin{tabular}{|l|l|l|}
\hline Team member & Responsibility/research aspect & Contact \\
\hline Manuel Boissière & Team coordinator/ethnobotany & m.boissiere@cgiar.org \\
\hline Ha Thi Mung & Socio-economy & mungbmt@yahoo.com \\
\hline Imam Basuki & Socio-economy & i.basuki@cgiar.org \\
\hline Le Hien & Socio-economy & Hienle2001@yahoo.com \\
\hline Meilinda Wan & Socio-economy & m.wan@cgiar.org \\
\hline Douglas Sheil & Ecology & d.sheil@cgiar.org \\
\hline Piia Koponen & Ecology & p.koponen@cgiar.org \\
\hline Nguyen Van Luc & Botany & vanluc_qh@yahoo.com.vn \\
\hline Vu Van Can & Botany & Tel. 04-861-6946 \\
\hline Ho Thi Bich Hanh & Translator & hanhdhkt@gmail.com \\
\hline Nguyen Quy Hanh & Translator & Quyhanh2000@yahoo.com \\
\hline Tran Thu Anh Anh & Translator & hianhanh@yahoo.com \\
\hline
\end{tabular}

\section{Village activities}

Consisting of one or two researchers assisted by a translator, the village team was responsible for all socio-economic data collection. The team used questionnaire and data sheets to interview most households and key informants and to record 
the results of community meetings and focus group discussions. Information was gathered from each household head on socio-economic aspects (demography, sources of income and livelihoods) and some other cultural aspects (history of the village, social organization, stories and myths, religion). The questionnaire and data sheets also provided basic information on local views by gender, threats against biodiversity and forests, perspectives on natural resource management and conservation, and land tenure.

Participatory mapping exercises began during the very first days of the survey with two women and men groups of villagers using two basic maps, assisted by two research members to explain the objectives of the exercise. They facilitated the process through discussion with villagers about which resources and land types to add to the basic maps. These maps were then put together to build a single map representing the perception of the overall community. During all our onsite activities, the map was available to any villager for adding features and making corrections. In the case of Khe Tran, we worked a second time with a group of key informants to increase the precision of the map, and two young villagers drew the map again with their own symbols.

Village activities involved:

(a) community meetings to introduce the team and its activities to the village members, to cover basic information on land and forest types available, location of each type (through participatory resources mapping) and categories of use that people identify for each of these landscapes and resources;

(b) personal and small groups interviews to learn about village and land use history, resource management, level of education, main sources of income, livelihoods and land utilization system;

(c) focus group discussion on natural resource location, land type identification by category of uses, people's perception of forests, sources of products for household consumption and important species for different groups of informants using the scoring exercise known as 'pebble distribution method', or PDM. PDM was used to quantify the relative importance of land types, forest products and species to local people by distributing 100 pebbles or beans among illustrated cards representing land types, use categories or species (Figure 1). In the following tables and figures with information from PDM, the $100 \%$ value refers to the total number of pebbles. The pebbles were distributed by the informants among the cards according to their importance.

\section{Field activities}

The field team consisted of four researchers assisted by one translator, two local informants and a field assistant. This team was responsible for botany, ethnobotany and site history data collection. It gathered information through direct observations, measurements and interviews in each sample plot using structured datasheets. 


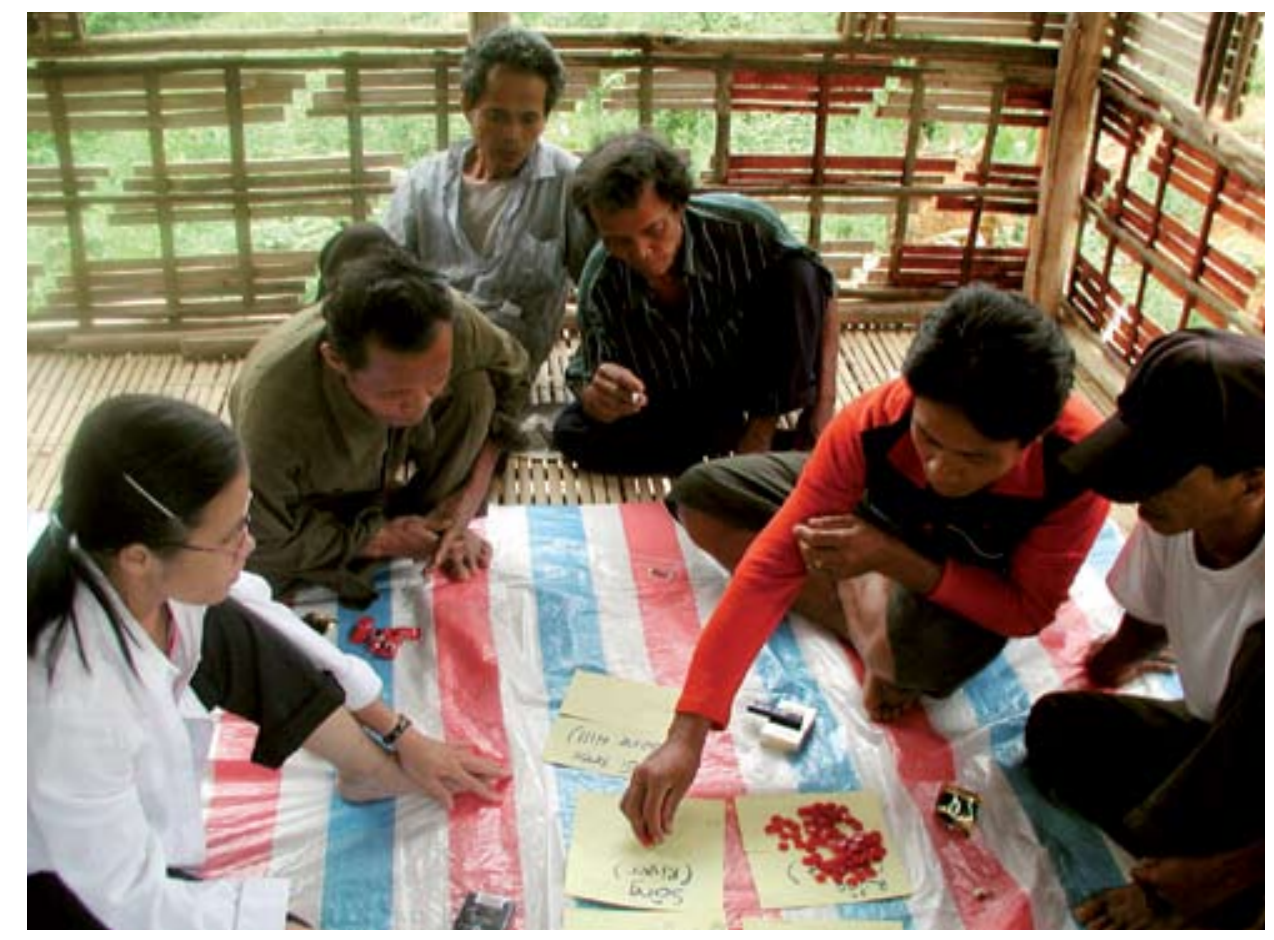

Figure 1. Scoring exercise (PDM) with Khe Tran men group

Activities in the field were decided on and set up in accordance with information collected in the village. The field team collected data from sample plots (Figure 2). The team chose plot locations after the different land types had been identified by the villagers. Sampling of land types took into account the main categories of the land types and sites where the most important resources could be found. Village informants accompanying the field team provided details on history and land use of each site, as well as the uses and names of the main forest products that were traditionally collected there. Although the sampling effort was distributed across most of the land types, forest habitats were given emphasis since they cover the largest area and generally house more species per sample than other land types. Most of the land types were sampled with one (rice field, primary forest) or two plots, in total 11 plots were surveyed with 110 subplots. For each plot a general site description with tree and non-tree data and detailed ethno-ecological information was composed and plot position was recorded with GPS. Plots consisted of $40 \mathrm{~m}$ transects subdivided into 10 consecutive $5 \mathrm{~m}$ wide subunits, where the presence of all herbs, climbers with any part over $1.5 \mathrm{~m}$ long and other smaller plants was recorded. Trees with a diameter at breast height ( $\mathrm{dbh})$ of $10 \mathrm{~cm}$ or more were censused and their height and diameter measured using the same base-transect but variable area subunits (Sheil et al. 2003).

Collaboration between village team and field team was crucial to the collection of relevant information, but collaboration with villagers was also important to link the data collected by direct measurements with those coming from discussions, 


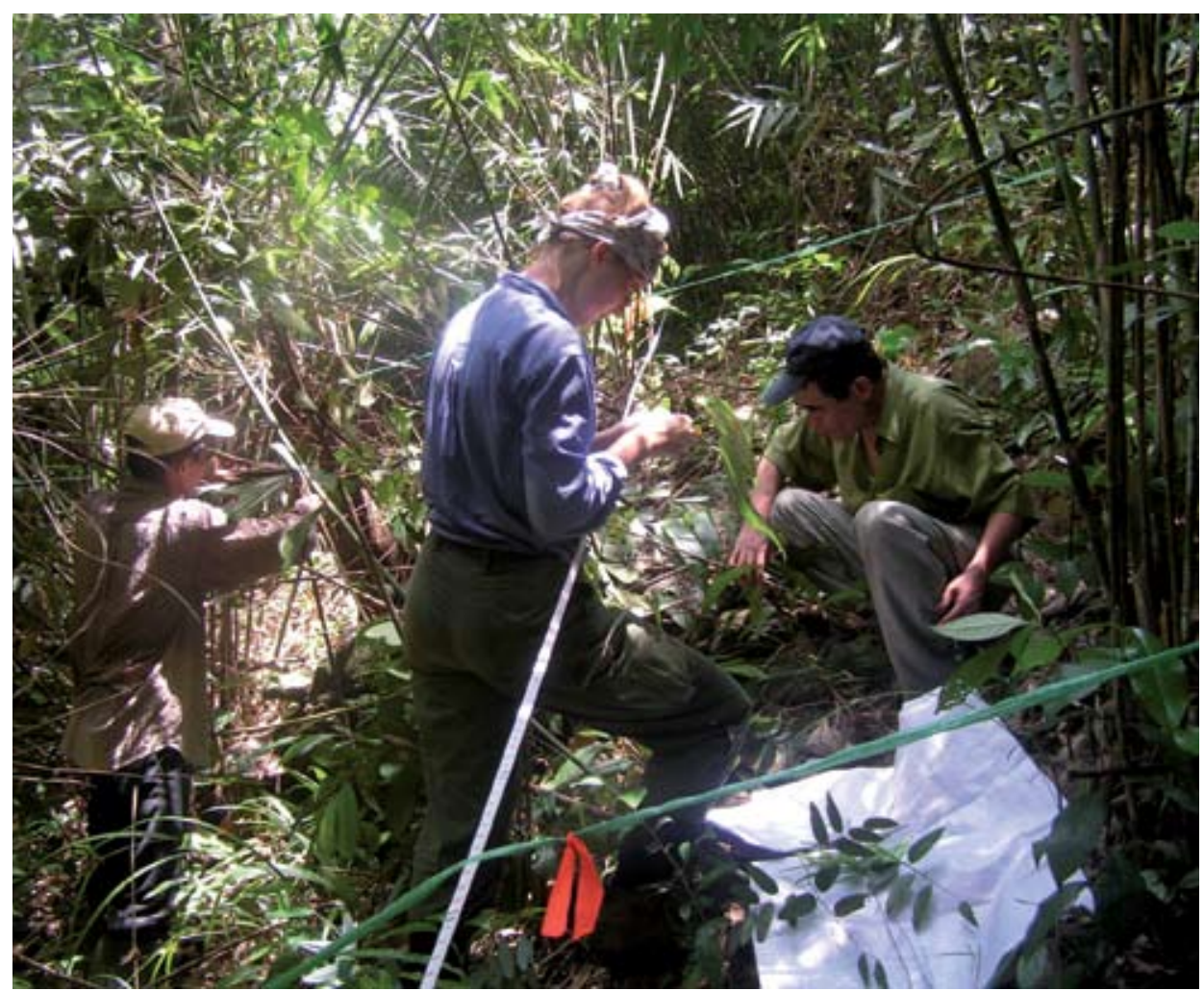

Figure 2. Working on sample plot

interviews and questionnaires. Preparation of the final reference list of plants with their corresponding local-language names took considerable time because of the mixture of Vietnamese language and Pahy language used by the local people. Some specimens identified to one species had several local names (e.g. Ageratum conyzoides) and other specimens with one local name belonged to different species (e.g. Fibraurea tinctoria and Bowringia sp.). A. conyzoides was given two local names (Cá hỡi and Sắc par abon) by different informants at different sites along with different uses. (Being bad for soil, Cá hỡi has few uses, while Sắc par abon was mentioned as potential fertilizer for sweet potato, although another informant said that it is actually not used by villagers). Catimbium brevigulatum, which was recorded in seven plots, had four different local names (A kai, A xây cỡ, Betre, Papan). Although informants were reliable and persistent in their ways of naming species, both gender and different experiences caused variation and the mixture of different languages (mainly Pahy and Vietnamese) was sometimes confusing for the researchers. The ethno-botanical survey was conducted simultaneously in the field, where we had in total 12 informants, normally two or more at the same time with both genders represented. This was important to ensure the broad sampling of knowledge about uses and sites. As an example, genus Bowringia, which was present in four plots in two land types (secondary forest and primary forest), had no use according to five informants, whereas two informants said it was used as firewood and its roots could be sold. 
From each plot plant specimens for further herbarium identification were collected. The entire specimen collection has been left with botanist Vu Van Can in Hanoi. All specimens were conserved in alcohol before drying and identification. Some specimens were identified in the field, others later in Hanoi. Genus and species names follow the nomenclature used in Iconographia Cormophytorum Sinicorum (Chinese Academy of Science, Institute of Plant Research 19721976), Cây cỏ Việt Nam (Pham Hoang Ho 1993), Vietnam Forest Trees (Forest Inventory and Planning Institute 1996), Yunnan Kexue Chubanshe (Yunnan Shumu Tuzhi 1990) and the International Plant Names Index database (http://www.ipni. org/); and family names in The plant-book: a portable dictionary of the vascular plants (Mabberley 1997) and the International Plant Names Index database except Leguminosae sensu lato, which follows the subfamily categorization of Mimosaceae, Fabaceae sensu stricto and Caesalpiniaceae.

The study in Khe Tran covered two periods, from 15 May to 9 June 2005 and from 2 to 15 October 2005. The first period was reserved mainly for data collection on the importance of local land types, while during the second period we focused more on quality control and biodiversity and conservation aspects according to local people. During both periods, commune officers joined the research team to make sure that we were safe. Even if their presence was not directly useful to our research, it was an opportunity for researchers to socialize with local authorities and discuss local perspectives on biodiversity and land types. 


\section{Achievements}

During the project, our objectives were to

(a) test and adapt the MLA method as an appropriate mechanism for integrating local perceptions and views in decision making and planning. The method was successfully tested in the rural context of Khe Tran, and even if the MLA was originally designed for assessments of local perceptions and priorities of forest dependant societies in a tropical context, we have shown here that the method can be adapted to situations where local communities rely less on the forest products than they used to;

(b) provide baseline data that can be used for the biodiversity conservation of the planned Phong Dien Nature Reserve. We have a considerable data base from our different surveys in Khe Tran, with an amount of important information on local priorities and perceptions, on the richness of the vegetation in the village's vicinity, on the uses of forest and non-forest products by the local people as well as on the economic, social and demographic data of the village. Seven hundred and fifty-four specimens of plants were recorded, consisting of 439 species from 108 families, for which we registered 824 uses. All these data, including socio-economic data will be valuable for the successful management of the planned nature reserve, providing information on the biodiversity in the buffer and core zones, and on the different uses and valuation of species and of natural resources by the local people;

(c) provide an overview of the importance of landscape and local species to the people of Khe Tran and collect information on their livelihoods and perspectives on Phong Dien Nature Reserve. Through community meetings, participatory mapping and scoring exercises, the landscape of the research area has been studied. Findings reflect the local point of view and 
relative importance of each category of use. Direct field observations using systematic sampling supported the recorded local views of the importance of different species, land types and spatial design of the landscape;

(d) discuss the opportunities and constraints faced by conservation institutions in the future nature reserve regarding land allocation and forest rehabilitation schemes. Dialogue with local informants occurred during the survey, in focus group discussion, interviews and more informal discussions, to understand the local priorities and perspectives facing the future nature reserve planning. A workshop with local people was held at the end of the survey to discuss the implications of conservation according to the local point of view, the options for local people in the frame of the future nature reserve, the role they would like to play and the threats to biodiversity they identified; and

(e) facilitate greater involvement of local people and other stakeholders in decision making and planning at the local level. Based on survey results, workshops will be held at the provincial, communal and village levels to share our information and experience with all interested partners, stakeholders and decision makers, and discussions will be held to look for options to involve local communities in reserve management. Before these workshops another part of the project, called Future Scenario, was implemented as a follow-up of our activity in Khe Tran (Evans 2006). Future Scenario helped the local community in Khe Tran to build strategies for their future based on local knowledge and preliminary MLA results. A presentation of the local people's future scenario was made to the local authorities (commune officers).

Before we analyse the survey results, it is necessary to better understand the context of conservation in the Phong Dien area and who the villagers of Khe Tran are. 


\section{Conservation context in Khe Tran}

\subsection{Previous conservation activities}

Government of Vietnam (GoV) policies have affected the forest-related activities of Khe Tran village. Prior to 1992, the upland forest, one of the last remaining patches of lowland evergreen forest including and adjacent to Khe Tran, was considered a 'productive forest' and managed by logging companies under the Department of Forestry at the province level. Then in 1992 this site, 'dominated by a ridge of low mountains, which extends south-east from the Annamite mountains and forms the border between Quang Tri and Thua Thien Hue provinces', was recognised for its 'important role in protecting downstream water supplies and reducing flooding in the lowlands of Thua Thien Hue province' and designated as a 'watershed protection forest', a status it still has (Le Trong Trai et al. 2001).

In 1998, international bird conservation groups focused attention on the site after rediscovery of Edward's Pheasant (Lophura edwardsi) in these hills, a fowl thought extinct. Today the site is part of a government forest strategy to create a system of 2 million ha of special use forest (national parks, nature reserves and historical sites) throughout the country and it is listed as one of the sites destined to become a nature reserve (41,548 ha) in 2010 (Barney 2005).

Local forests around Khe Tran are one of the key biodiversity areas of the province, since many rare and endangered species of plants and animals can be found there. Le Trong Trai et al. (2001) report that significant numbers of endemic and nonendemic plants, mammals, birds, reptiles, amphibians and butterflies are found in Phong Dien forests including Khe Tran. Endangered tiger, Panthera tigris, was confirmed to be present in this area. Muoc, who belongs to the Pahy ethnic group from Khe Tran, reported that in March 1998 he observed a tiger of approximately $100 \mathrm{~kg}$ at 200 meters from his village. He also reported that in May 1998 a tiger preyed on one of his buffalo in the Moi valley $\left(16^{\circ} 27^{\prime} \mathrm{N} 107^{\circ} 15^{\prime} \mathrm{E}\right)$. He further noticed that, judging by the footprints, two adults and one cub were present. Villagers also reported during our survey the regular presence of some of the globally threatened green peafowl (Pavo muticus), although these reports 
remain unconfirmed. Some of these key biodiversity species are closely related to the livelihood of the local people. Our study analyses this kind of knowledge.

First among the threats to forest biodiversity identified by BirdLife International and the Forest Inventory and Planning Institute (FIPI) is hunting, because of the value and rarity of the game, followed by firewood and other nontimber forest product (NTFP) collection, timber cutting, forest fires (including human-made as part of scrap metal collection) and clearance of forest land for agriculture (Le Trong Trai et al. 2001). But the threats are usually specific to each site, and detailed information is needed for each location, as we did in Khe Tran.

In June and July 2001, the nature reserve project team including the project leader and two local people, in collaboration with the Phong Dien Forest Protection Department (FPD), conducted hunting surveys in Khe Tran and other parts of the future Phong Dien Nature Reserve (PDNR). International Nature Conservation made this investigation in the frame of a project named 'Understanding the impacts of Hunting on Edwards's Pheasant Lophura edwardsi at PDNR, Vietnam: Towards a Strategy for Managing Hunting Activities'. Interviews were conducted with villagers, village leader, hunters/trappers (hereinafter called hunters) and wildlife traders. Villagers also helped to cross-check information obtained in the field. During the initial meetings with hunters in the future core zone, the team was accompanied by a local guide. The guide helped to introduce the survey and emphasized its scientific nature. This helped the socialization of the team's activities and to gain local support and trust (see the report in http://www.rufford. org/rsg/Projects/reports/Tran_Quang_Ngoc_Aug_2001.doc).

The Protection Area and Development review, in collaboration with the World Wildlife Fund (WWF), BirdLife International and FPD undertook another field study in Khe Tran and other specific sites of Thua Thien Hue province in late 2001 and early 2002. The objective was to examine the actual and potential economic contribution of the protected areas to different economic sectors in the province and to define important policy and planning issues related to maintaining and enhancing the development benefits from the protected areas. This information helped policy-makers and planners to understand how their actions could influence protected area management, local livelihoods and associated economic development in the areas. A number of case studies also investigated specific connections between protected areas and economic sectors (see http://www. mekong-protected-areas.org/vietnam/docs/vietnam-field.pdf).

A project on Community Participation for Conservation Success developed by WWF, Xuan Mai Forestry University and FPD used Khe Tran as one of the training sites in buffer zones. It was designed to increase the effectiveness of conservation programs in Vietnam by promoting community participation through communitybased environmental education (CBEE). The project, started in 2003, aimed to increase the immediate and long-term capacity of government to incorporate CBEE training into mainstream training institutions. It also contributed directly to conservation actions in two priority sites in the Central Annamite, by integrating CBEE activities into the implementation of protected area conservation projects (Matarasso and Do Thi Thanh Huyen 2005). 


\subsection{Government programs that affected Khe Tran village}

Swidden cultivation was a major activity for local livelihoods until 1992-1993, when most of the households were resettled as part of the government's fixed cultivation program. Called '327 Program' (1992-1997), it was the first effort of the GoV to develop industrial plantations and to decentralize control over and reallocate benefit-sharing of forest resources in Vietnam (Barney 2005), in line with the 'Doi Moi' economic reform (which, with six major economic changes, helped Vietnam come out of the economic crisis in 1986). Since then most of the Khe Tran people have concentrated more on their new agriculture and plantation land and decreased their activity in the natural forests. In this community, there was little land suitable for wet rice cultivation, and villagers began to cultivate crops such as maize and peanuts, and to diversify crop production with rubber and Acacia plantations supported by the national 327 Program.

In 2003, according to Artemiev (2003), new guidelines were formed on State Forest Enterprises (SFE) by various government institutions (see Prime Minister Decision 187/1999/QĐ-TTg from September 1999 and Political Bureau Resolution $28-\mathrm{NQ} / \mathrm{TW}$ of 16 June 2003 on the arrangement, renovation and development of State Farm and Forest Enterprises), which reformed its status to

1. business SFE (forestry related business), which earns profits as its main performance objective and receives no subsidies to cover its operating cost;

2. Protection Forest Management Board (forest protection activities), which combines earned profits and subsidies only for cost recovery;

3. other business form (transportation, construction, wood processing, extension services, etc.), which is similar to business SFE in its objective; and

\section{4. public utility State Owned Enterprises.}

For more than one decade forestry activities have been implemented under a series of national forest development programs, most recently the ' 661 Program' and its predecessor, the 327 Program. In Phong Dien district, the 661 Program is managed by Phong Dien Forest Enterprise and the management board of Bo River Watershed Protection Forest (Le Trong Trai et al. 2001). The main forestry activities focused on 'afforesting' bare lands and degraded areas, and establishing forest plantations. In Khe Tran village, households were paid VND 700,000 to VND 1 million per hectare for planting trees on land allocated for plantations (Acacia spp.). They were then paid a further VND 450,000 for the first year and VND 250,000 for each of the next two years under the terms of the forest protection contract (for comparison, the average annually per capita income in Khe Tran is VND 1,944,167). They were not allowed to cut the trees but, in places with older trees, were allowed to collect fallen branches for firewood. In A Luoi district, for example, households were paid VND 400 per tree for planting cinnamon trees, which equals VND 4 million/ha (high planting density of Cinnamomum cassia is 10,000 trees/ha; Le Thanh Chien 1996). 
Further, Le Trong Trai et al. (2001) described that payments from these national forestry programs have provided benefits to villagers in the short term, and Acacia spp. and pine plantations established under these programs are growing reasonably well. However, villagers brought attention to a number of problems they had to face in response to the needs of the national forestry programs. For example, villagers from Khe Tran and Ha Long pointed out that they faced considerable difficulties after their individual agreement (temporary Land Use Certificate) on plantation with the Forest Enterprise expired, and they were left without any further incentive. This kind of agreement does not provide any official recognition of the local people's rights to the land, and they only have the right to use the land, temporarily, for the time of the agreement. These same villagers expressed a preference for natural forest management approaches that deliver sustainable and regular benefits and allow them to manage existing forest land (including regenerating forest and 'bare' lands) in a more sustainable manner.

In Phong Dien district, the main species for plantation establishment are Acacia auriculiformis, Acacia mangium and Pinus kesiya, selected by project managers of the national forestry programs. The total area under forest plantation is substantial: according to Phong Dien Forest Enterprise, 30,366 ha of plantations have now been established in the three communes of Phong Dien district near the buffer zone, with support from the 327 and 661 programs. Most plantations have been established on flat lands and lower slopes, for accessibility and financial reasons.

Rubber trees were also established under the 327 Program in Khe Tran. Unfortunately, according to Le Trong Trai et al. (2001), this plantation was established on the river banks, the village's best lands available for agriculture crops. Because the trees already produce latex, villagers are left without any better option for other agriculture. In our survey we observed that beyond the rubber plantation and the plain area in the lower part of the village, land is composed of reddish, stony and hard soil surface.

Le Trong Trai et al. (2001) argued that with an abundance of heavily degraded land available for rehabilitation, forest management and other land uses, there is considerable potential for cash earning activities in the buffer zone (for example through economic crop plantations). This activity would also reduce the overall pressure on the forest resources in the nature reserve. They also suggested that current arrangements for forest development and management in the bare lands are costly, create social tensions and seem to be unsustainable in the long run. On the other hand some of the Acacia plantations have been established in areas that are not optimal from environmental or economical perspectives. This practice may lead to increasing conflicts, especially as land pressure for crops continues to increase. Consideration might, therefore, be given to allocating a greater proportion of existing forest lands for community management. 


\section{Summary}

Khe Tran village has been through different land use policies. Its forests were first considered productive forests, then watershed protection forests, and it is planned to be part of Phong Dien Nature Reserve in 2010, because of its important biodiversity and the presence of rare and endangered species. However, forests in the village's surroundings have been deeply disturbed, because of war, logging activities and agricultural practices. Many projects linked to the preparation of the nature reserve have taken place in Khe Tran. Banning local people from many extractive activities in the planned reserve, the government has proposed to develop other activities to provide incomes to all households. In this context, rubber and Acacia plantation programs were implemented with government support. Even if these programs are supposed to provide cash income to the local people, some villagers worry about their future rights on the plantations and expect to get rights to manage the natural forests and the bare land in a sustainable way. Lack of land for agriculture may become a problem for food security and may leave many villagers with few alternatives to the exploitation of the natural forest. 


\section{Site description}

\subsection{Research site}

Khe Tran (Phong My commune, Phong Dien district, Thua Thien Hue province) is situated near the limits of the future Phong Dien Nature Reserve (PDNR) (Figure 3). The village covers an area of about 200 ha and its average elevation is $160 \mathrm{~m}$ asl. Located to the north-west of Hue city, it can be reached by car in 1.5 hours from the provincial capital. During the rainy season flooding regularly isolates the village for several days. Khe Tran is bordered by the Phong Dien Nature Reserve on the west and south, and by Hoà Bac village on the east.

The village is in the buffer zone of PDNR, an area of forest and converted lands. The reserve and the village area are dominated by low mountains, which extend south-east from the Annamite Mountains and form the border between Quang Tri and Thua Thien Hue provinces. The highest points within the nature reserve are Coc Ton Bhai (1,408 m), Ca Cut (1,405 m), Ko Va La Dut (1,409 m), Coc Muen $(1,298 \mathrm{~m})$ and Co Pung $(1,615 \mathrm{~m})$.

Very little natural forest remains in the village vicinity, and plantations cover an increasing portion of the abundant bare lands. Village houses are scattered on both sides of a small trail, $1 \mathrm{~km}$ from the main road running between Phong My and Hoà Bac. One characteristic of the village is the isolation of the houses from each other, and it takes approximately 30 minutes to walk from one end to the other of this village of 20 households. Home gardens commonly consisting of pepper and jackfruit are surrounding most of the houses.

This place was chosen for our project as the reference site for the MLA activities for several reasons:

1. There is a strong presence of a minority group, the Pahy, in the village, mixed with some Kinh (the majority ethnic group in Vietnam) and Khome (an alternate name for one of the Khmer language groups in Vietnam; see Gordon 2005). There are 53 ethnic minorities in Vietnam (12.7\% of the population in 1979 census) and some of them have problematic relationships with the main ethnic group, represented by the central government (Yukio 


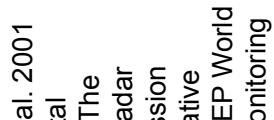

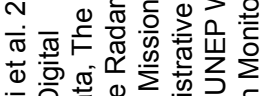

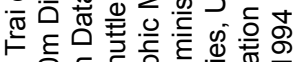

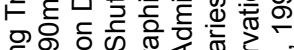

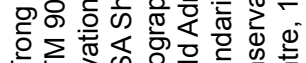

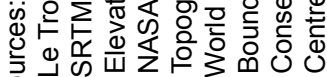

œ.

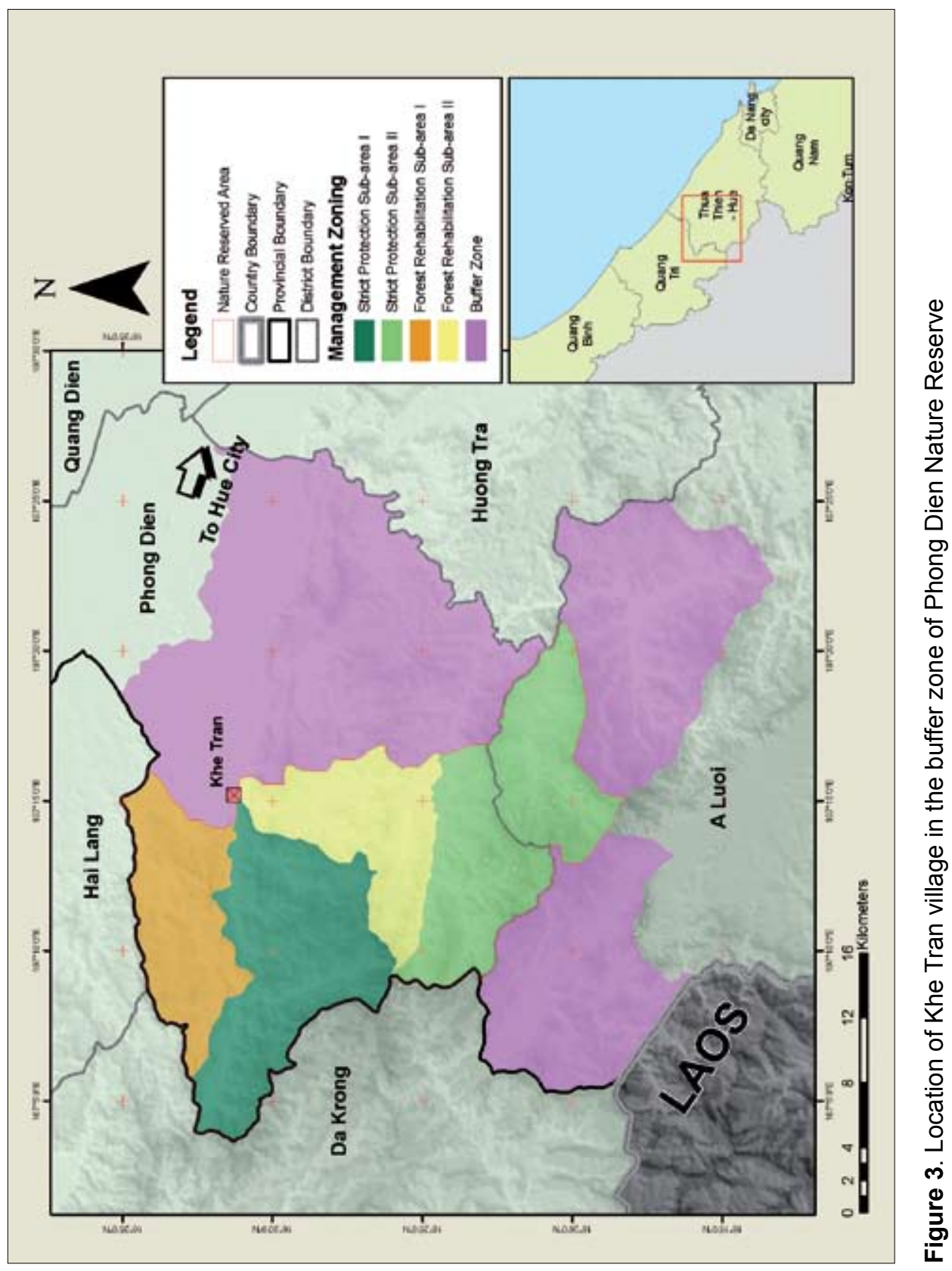


2001). Generally the main conflicts occur in the Central Highlands (conflicts over land allocation to Kinh people, problems of traditional land management and of shifting cultivation), and ethnic minority groups often are not well perceived by the Kinh. Nevertheless, the GoV has recently made efforts to recognize the situation and vulnerability of minority groups and has developed a policy of integration of these groups into the more global economic life, through development and infrastructures programs (ADB 2005). We found it relevant to work with a local community belonging to a minority group that was already mixed with the main Kinh group. The fact that this community has been forbidden to practice its traditional shifting cultivation activities, and encouraged to follow the more sedentary mode of agriculture, was one more reason for us to study its perception and priorities for natural resource management, and how it manages its relationships with other village groups and government authorities at commune, district and provincial levels.

2. A second important reason was the presence of a future nature reserve in the village's vicinity. This reserve, decided on after the discovery of Edward's Pheasant in the mountains of Phong Dien district, is planned for 2010 (BirdLife International et al. 2001) and has great potential for local communities' involvement, although at this time people from Khe Tran and other villages at the limit of the reserve are forbidden to pursue any extractives activity inside the future core zone. Yet our survey could provide valuable information on the way local people envisage their possible participation in reserve management and for negotiations among all stakeholders.

3. Last, most of the projects in Phong Dien district focus on mines and infrastructure, while few seek to gain experiences in land use planning (some projects have developed activities in community forestry, but mainly plantation forests). Results from our activities can be used for comparison with similar projects undertaken in other districts of Thua Thien Hue, or even other provinces of Vietnam.

\subsection{People from Khe Tran}

\subsubsection{History of the people from Khe Tran}

Prior to 1967, Khe Tran village was situated around the upstream portion of the O Lau and My Chanh rivers (see Figure 4). The villagers practiced shifting cultivation in this hilly area. They were displaced by war to A Luoi district and even Laos PDR. In 1971, the GoV informed them that their homeland was safe and that they could re-occupy it. The village leader and a few other villagers returned to Tam Gianh, a place situated $2 \mathrm{~km}$ from the actual settlement, upstream on $\mathrm{O}$ Lau river, and the remaining refugees followed soon after. The displaced Khe Tran villagers settled there for five years, before moving on to Khe Cat village, where they remained until 1978. Finally, they re-occupied their former homeland, the upstream part of O Lau river. In 1992, encouraged by the government to settle closer to the main road, some villagers moved to Khe Tran lowlands (the lower part of O Lau river 

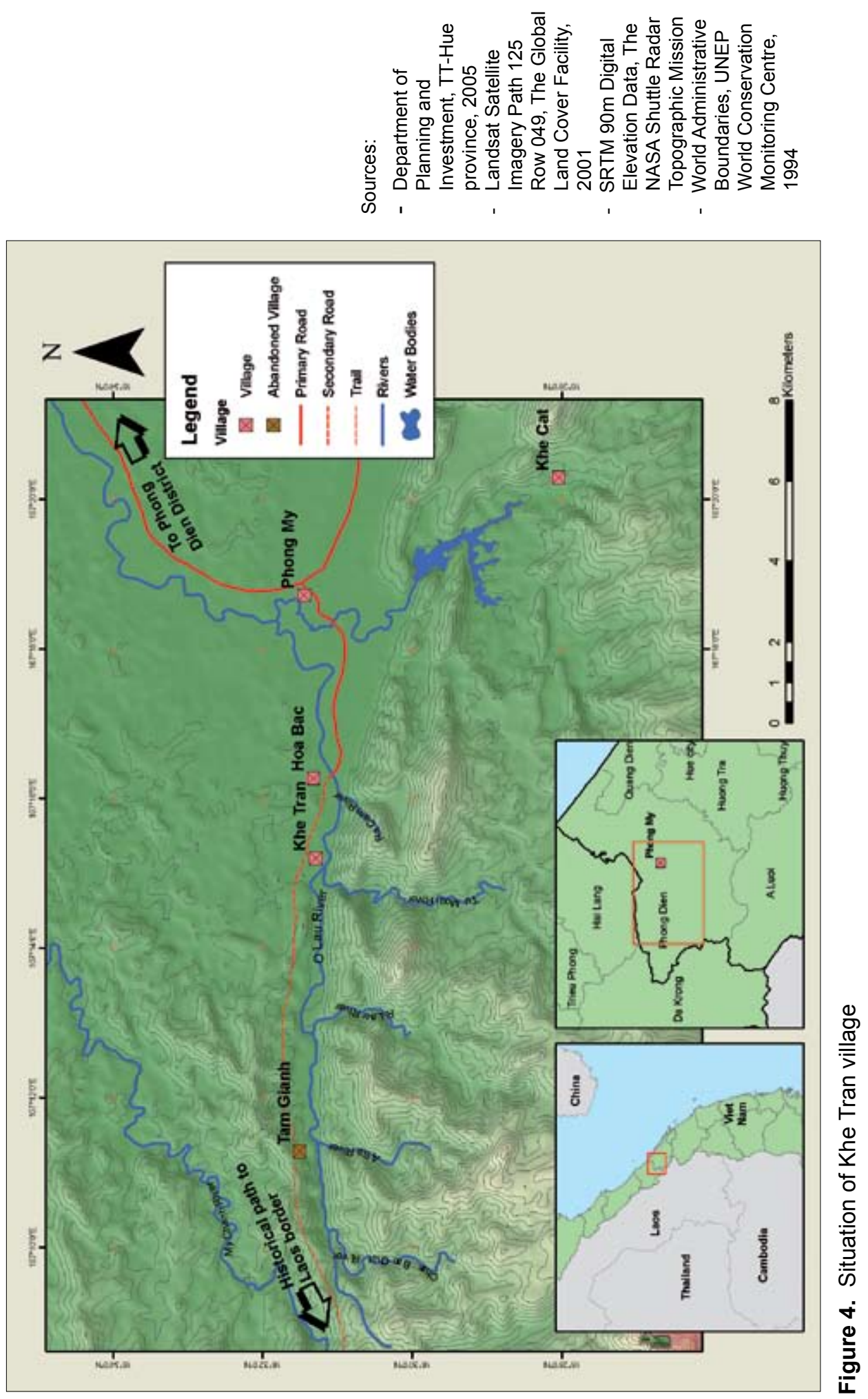
in the lower part of the village), thus moving away from the lands traditionally occupied by the Pahy. Most of these villagers were of mixed ethnic origins. This is how the village became divided into two parts, as mentioned before, on the upper and lower reaches of the $\mathrm{O}$ Lau river; with support from the government the villagers living in the lowlands developed agricultural crops (including rice) and rubber plantations.

\subsubsection{Population and ethnicity}

One hundred twenty-four villagers, divided into 20 households, live in Khe Tran. People 15 to 60 years old represent $71 \%$ of the population, the remainder being composed of children (21\%) and seniors (8\%). Most villagers are farmers and only a few have other occupations such as police, teacher or tailor.

As mentioned before, most of the villagers belong to the Pahy ethnic group, one of the many minority groups found in Vietnam; 23 people are Kinh, which is the majority ethnic group in Thua Thien Hue province and in Vietnam generally (Vu Hoai Minh and Warfvinge 2002). There is a single representative of the Khome ethnic group. Originally only Pahy people inhabited Khe Tran and the surrounding areas, but with time other ethnic groups have settled in the region through intermarriages. Pahy and Kinh people live together in both the upland and lowland village parts.

Interactions between government and minorities like the Pahy are sometimes strained, especially in respect to land and natural resources rights of usage. Working with the Pahy of Khe Tran allowed us to study the situation of a minority group for which the process of integration and transformation is practically achieved, and our observations may be of value as a basis for comparison with other groups in Central Vietnam.

\subsubsection{Education}

Only eight villagers have not received an education. The villagers who have received the most years of education are young people (under 30 years old), most of whom have finished elementary school. A very few have gone to high school.

The sole elementary school is located in a nearby village on the way to the commune (Phong My). The primary (middle) school is at the commune $(5 \mathrm{~km}$ from the village), and secondary (high) schools are located in Phong Dien district. There was an elementary school in the village, but it closed for lack of students.

Most of villagers hope for better education, infrastructure and institutions. They think that education can help them to increase their welfare by providing their children with useful knowledge and skills.

\subsubsection{Livelihood}

Villagers of Khe Tran work most of the time in their rice fields, in their home gardens (mostly growing pepper and jackfruit) and in rubber and Acacia plantations 
as a result of the government resettlement program. Despite these new sources of income, people still occasionally gather forest products (e.g. honey, rattan) and war wreckage from the nature reserve. Some villagers still depend on nature reserve forests, but an increasing number of people depend on more permanent agriculture and plantation for their livelihoods and for cash earning. Villagers in the lowlands principally depend for their livelihoods on cultivation of seasonal crops, plantations, livestock and home gardens, whereas those in the uplands are relying on plantations and livestock (Figure 5).

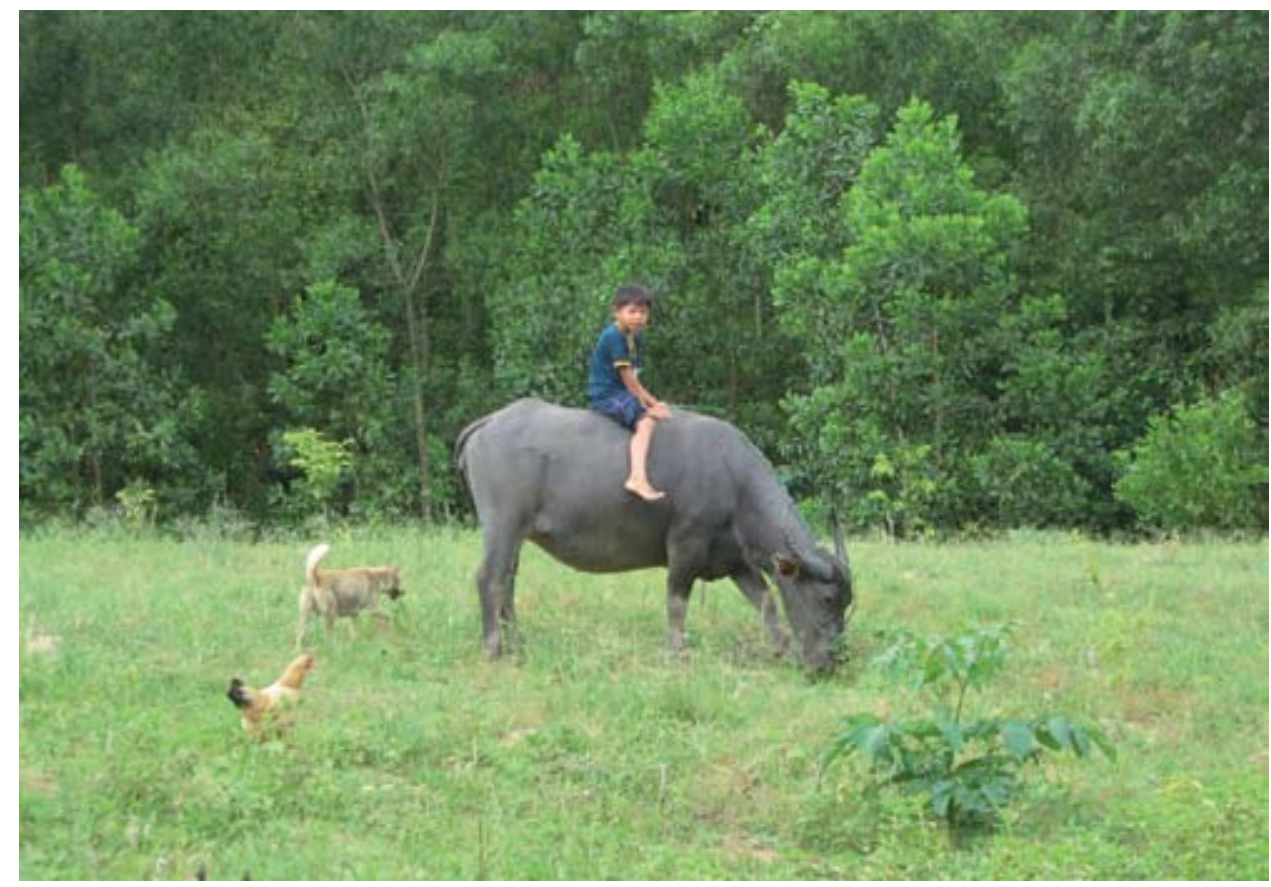

Figure 5. Livestock and Acacia plantations are important in Khe Tran

Some important events have affected the livelihoods of the villagers. Until recently, the inhabitants of Phong Dien districts, including Khe Tran village, had to cope with problems of flooding, drought and forest fire. For example, floods caused widespread damage to crops and infrastructure in 1983 and 1999. During the 1999 floods, houses, crops and even lives were lost in Khe Tran. Widespread fires and drought were also reported in the district in 1985, and another drought occurred in 1990. We recorded these events which started from 1992, when some villagers started to settle in the lower part of the village (Table 2).

\subsubsection{Source of income}

There is a big difference between the two parts of the village in terms of household income (Table 3). According to the household survey, people from the lower part have a higher annual income (average of VND 13.7 million) than those from the 
Table 2. Important events affecting the local livelihoods

\begin{tabular}{|l|l|l|}
\hline Year & Disasters/important events & Causes \\
\hline 1992 & Settlement in Khe Tran village & Following government plans \\
\hline 1993 & Forest assigned to villagers & $\begin{array}{l}\text { Because previous forest management by } \\
\text { the government failed to prevent forest } \\
\text { destruction, forests were assigned to local } \\
\text { people (reforestation program). This helped } \\
\text { the local people to use the bare lands, which } \\
\text { are still officially included in the forest } \\
\text { category }\end{array}$ \\
\hline 1999 & Flood & $\begin{array}{l}\text { Natural disaster which damaged/destroyed } \\
\text { some houses }\end{array}$ \\
\hline 2003 & Access to electricity & Government program \\
\hline 2004 & $\begin{array}{l}\text { Access to water for irrigation } \\
\text { (self-running water system) }\end{array}$ & Government program for poverty alleviation \\
\hline
\end{tabular}

upper area (VND 9.6 million). The average household contains six members, with an income of VND 1.6 million to VND 2.3 million per capita. These values are much lower than the general per capita income in Vietnam of USD 553, or VND 8.7 million in 2004 (http://www.state.gov/r/pa/ei/bgn/4130.htm). We found that some households' income was below the poverty line of VND 1.04 million per capita (Vietnam General Statistical Office at http://www.unescap.org/Stat/meet/ povstat/pov7_vnm.pdf\#search='poverty\%20line\%20in\%20vietnam').

Rubber (Figure 6) and Acacia plantation, livestock, home gardens and retirement subsidies are the main source of income for the lower area, while Acacia plantations and war subsidies (compensation) represent the main source for the upper part. People from the upper part have little cash income from livestock, rattan, home gardens and the collection of war wreckage.

Some of the villagers were in the army during the war against the USA, and they still receive compensation from the government. Two villagers have opened small shops that sell drinks and foods. The owners lay in supplies at the market of Phong My commune. Some villagers work in Phong Dien as teachers and police officers, and one is a tailor in Ho Chi Minh City.

Villagers living in the upper part are near the natural forest and use it when they experience food shortages. Food security is critical in the upper part as they do not cultivate rice and for cash income depend on Acacia plantation. Efforts to intensify livestock and home garden production may help to improve their income and to secure food availability. Maltsoglou and Rapsomanikis (2005) reported that livestock plays an important role in household income in rural areas of Vietnam.

Acacia plantation is a potential source of substantial income for households nowadays and may become even more important in the future. Demand for local Acacia production is significant and absorbs all harvested products in Khe Tran. Demand from pulp and chipboard factories located near Thua Thien Hue and the GoV program to expand the plantation area (Barney 2005) bode well for forest plantation as a means to increase local income. Plantation may also provide fodder for livestock. 
Table 3. Income range by source of products and settlement area

\begin{tabular}{|l|r|r|r|r|}
\hline \multirow{2}{*}{ Source of income } & \multicolumn{4}{|c|}{ Household income (VND millions) } \\
& \multicolumn{2}{|c|}{ Lower area } & \multicolumn{2}{c|}{ Upper area } \\
\hline Rubber plantation & $0.27-0.67$ & $3.20-8.00$ & 0.00 & 0.00 \\
\hline Acacia plantation & 0.58 & 7.00 & $0.10-0.25$ & $1.20-3.00$ \\
\hline Livestock & 0.25 & 3.00 & $0.10-0.29$ & $1.20-3.50$ \\
\hline Home garden & 0.58 & 7.00 & 0.25 & 3.00 \\
\hline Pension & 0.61 & 7.30 & 0.60 & 7.20 \\
\hline Agriculture & n.a. & n.a. & 0.10 & 1.20 \\
\hline Rattan & 0.05 & 0.60 & n.a. & n.a. \\
\hline War wreckage & 0.00 & 0.00 & 0.02 & 0.20 \\
\hline Store & 0.00 & 0.00 & $0.05-0.58$ & $0.60-7.00$ \\
\hline Others & 0.17 & 2.00 & $0.03-0.15$ & $0.30-1.80$ \\
\hline Average & 1.14 & 13.70 & 0.80 & 9.63 \\
\hline Range & $0.35-2.08$ & $4.2-25$ & $0.33-1.67$ & $4-20$ \\
\hline
\end{tabular}

n.a. means respondents gave no information in regard to the small amount of income obtained from corresponding source

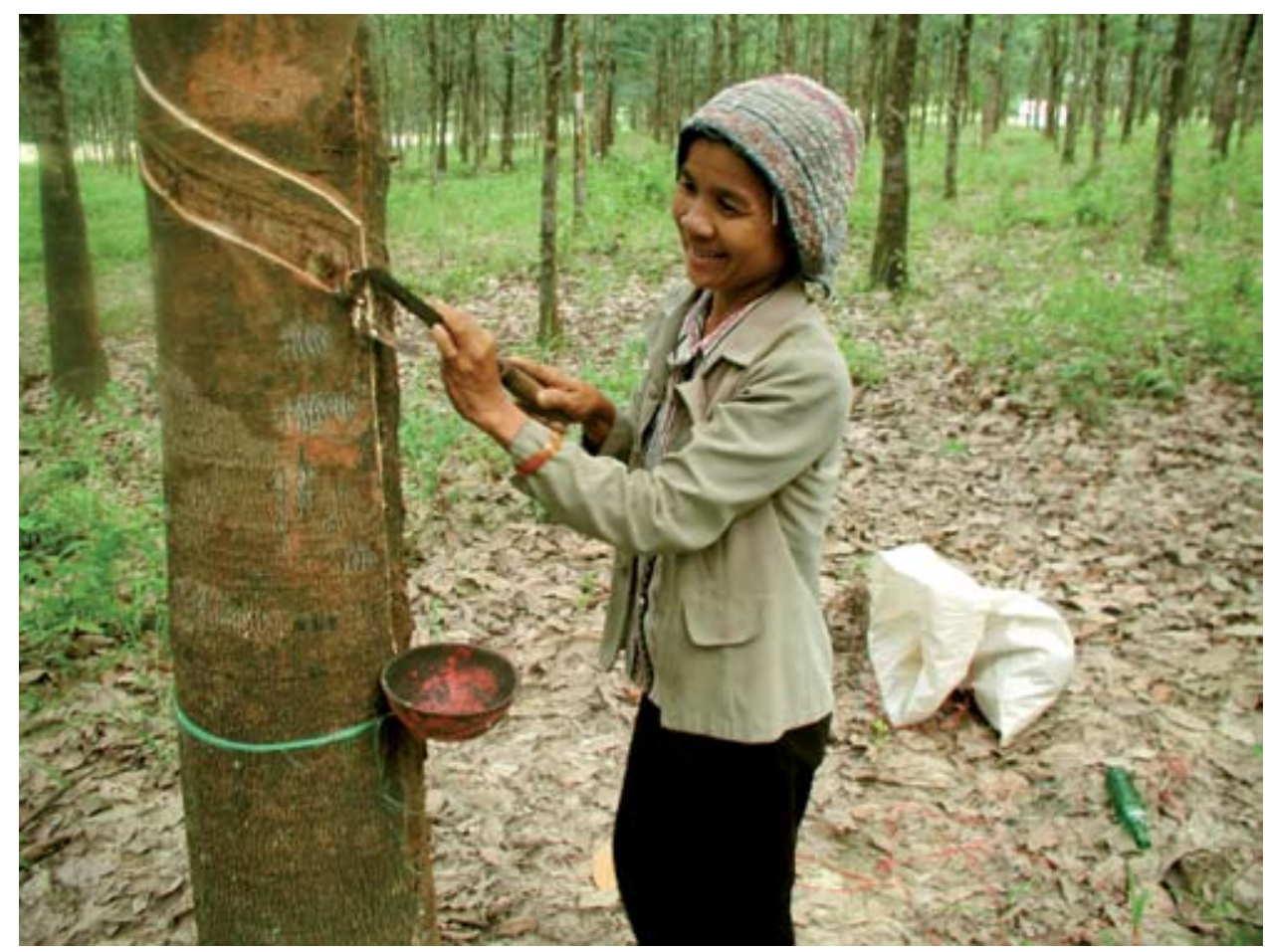

Figure 6. A woman from the lower part of the village harvests rubber from her plantation 
Another opportunity to increase and diversify income is to utilize the river for fish production. O Lau river, near the village, is approximately $20 \mathrm{~m}$ wide and in some parts has natural pools that offer potential for fish farming. Fisheries have been introduced and are popular in other areas of Phong Dien and A Luoi districts (Le Trong Trai et al. 2001) and may also prove useful in this village, even if there are great concerns in case of flood and about dioxin contamination of the river.

\subsubsection{Access and interaction with outsiders}

Access to the commune is good, with a $4 \mathrm{~m}$-wide path linking the village to the main road of the commune. Villagers use bicycles and motorbikes to go to the commune. During the rainy season, however, sections of the path are sometimes cut by floods, especially in the lower parts. The village road becomes muddy and slippery. A bridge connects the lower and upper parts of the village, and a bigger bridge is under construction with assistance from the Thua Thien Hue Rural Development Project (Appraisal Mission 2004).

Outsiders interacting with villagers are traders who buy agricultural products (peanut, pepper, rubber, cassava) or sell meat and clothes. Sometimes villagers meet outsiders who collect eaglewood, war wreckage or rattan, but there is little interaction. The coffee shops in the upper part of the village are the place where villagers frequently chat with outsiders.

Villagers reported that many extension workers from government and nongovernment institutions have held training courses in the village since the program of land allocation and reforestation started in the early 1990s. They think that these extension efforts have been very useful and hope to have more workshops especially on technical and management aspects of livestock, plantation and agriculture.

\subsection{Land use and natural resources}

In the village's vicinity the planned nature reserve and its buffer zone consist of patches of degraded forest, grassland, Acacia and rubber plantations, and areas reserved for agriculture. Two main rivers can be found near the village, the O Lau and My Chanh rivers.

During our first observations and community meetings, we identified the main surrounding land types, e.g. alluvial plain with settlements, pepper gardens, rubber plantations, rice fields and other dry-land agriculture, hilly areas with secondary forests, Acacia plantations, settlements, pepper gardens and grasslands. We recorded about 20 different land types identified by the villagers around Khe Tran (Table 4). The land type identification reflects the official perception and classification of land tenure (e.g. land reserved for settlement, land for peanut farming), along with some features less relevant to our activities (e.g. waterfall, small road, bridge).

We tried, therefore, to classify the local perception, rather than the official one, and the land types were regrouped into six main types, namely bare hills, 
Table 4. Identified land types in Khe Tran

\begin{tabular}{|l|l|}
\hline Land types (Pahy) & Description \\
\hline Cutect vườn & Land for garden \\
\hline Cutect màu & Land for agriculture \\
\hline Cutect a tong & Land for peanut farming \\
\hline Cutect along & Land for forest plantation \\
\hline Cutect vá & Land for cemetery \\
\hline Cutect cho tro & Land for rice farming \\
\hline Cutect tiêu & Land for pepper farming \\
\hline Cutect cao su & Land for rubber farming \\
\hline Cutect âm bút & Land for natural forest \\
\hline Cutect cỏ & Land for grass/bare land \\
\hline Đa puh Pahy & Pahy/O Lau river \\
\hline Đá so tù moi & Tu moi tributary \\
\hline Cutect ta xu & Land for houses \\
\hline Ân yên cooh 935 & Mountain peak of 935 \\
\hline A chuh Rana & Rana waterfall \\
\hline Chooh Rana & Sandy area of Rana riverside \\
\hline Mỏ zeeng & Gold mine \\
\hline Along papứt & Big tree forest \\
\hline Along cacet & Small tree forest \\
\hline Câm foong fứt & Bridge \\
\hline
\end{tabular}

dry land for agriculture, forests, home garden, rice field and rivers. The forests classification was further divided into plantation, small tree and big tree forests (see Table 5).

$\mathrm{O}$ Lau river is an important part of the landscape near the village. It traverses the entire village territory, close to the settlements. The second big river, My Chanh river in the northern part of Khe Tran, is rarely used by the local people.

Forests within and around the village are categorized into three types as mentioned above. Plantation forests in our survey include Acacia and rubber. The oldest ( 8 years) rubber plantation of the village is situated near the main road, and covers about 10 ha, including some patches of new plantations. The Acacia plantation begins in the middle of the village and reaches to the upper part, covering about 160 ha. Small tree forest represents the dominant types of forest around the village, mainly inside the Phong Dien Nature Reserve, and consists of young Myrtaceae and Rubiaceae forests. Big tree forest (or primary forest) is distant from the village, situated at more than one day's walk, inside the reserve area.

Bare lands (Figure 7) were caused historically by war, fires, grazing and shifting cultivation (Le Trong Trai et al. 2001). This land type, dominated by shrubs and grasses, is the target of reforestation efforts by the government. Acacia plantations are developed on these bare hills.

The rest of the village's landscape is divided into settlements, home gardens (pepper and fruits), bare hills, rivers and roads. If land for plantation is geographically specialized (Acacia in the upper part and rubber in the lower part), home gardens can be found near the houses in both parts of the village. 
Table 5. Regrouped land types in Khe Tran

\begin{tabular}{|l|l|}
\hline Land types (English/Pahy) & Description \\
\hline Home garden/Cutect vườn & $\begin{array}{l}\text { Mostly pepper with jackfruits and pineapples; } \\
\text { around houses }\end{array}$ \\
\hline Land for agriculture /Cutect màu & Peanut and cassava; lower part of Khe Tran \\
\hline Rice field/Cutect cho tro & $\begin{array}{l}\text { Dry rice field } \\
\text { North of the village; shrub and grass on hills and } \\
\text { riverbanks }\end{array}$ \\
\hline Bare land/Cutect cỏ & $\begin{array}{l}\text { South and north of the village (O Lau and My } \\
\text { Chanh rivers) }\end{array}$ \\
\hline River/Đa purh & Rubber and Acacia \\
\hline Forest plantation/Cutect along & Young regrowth around village \\
\hline Small tree forest/Along ca cut & West of the village (far from the village) \\
\hline Big tree forest/Along papứt &
\end{tabular}

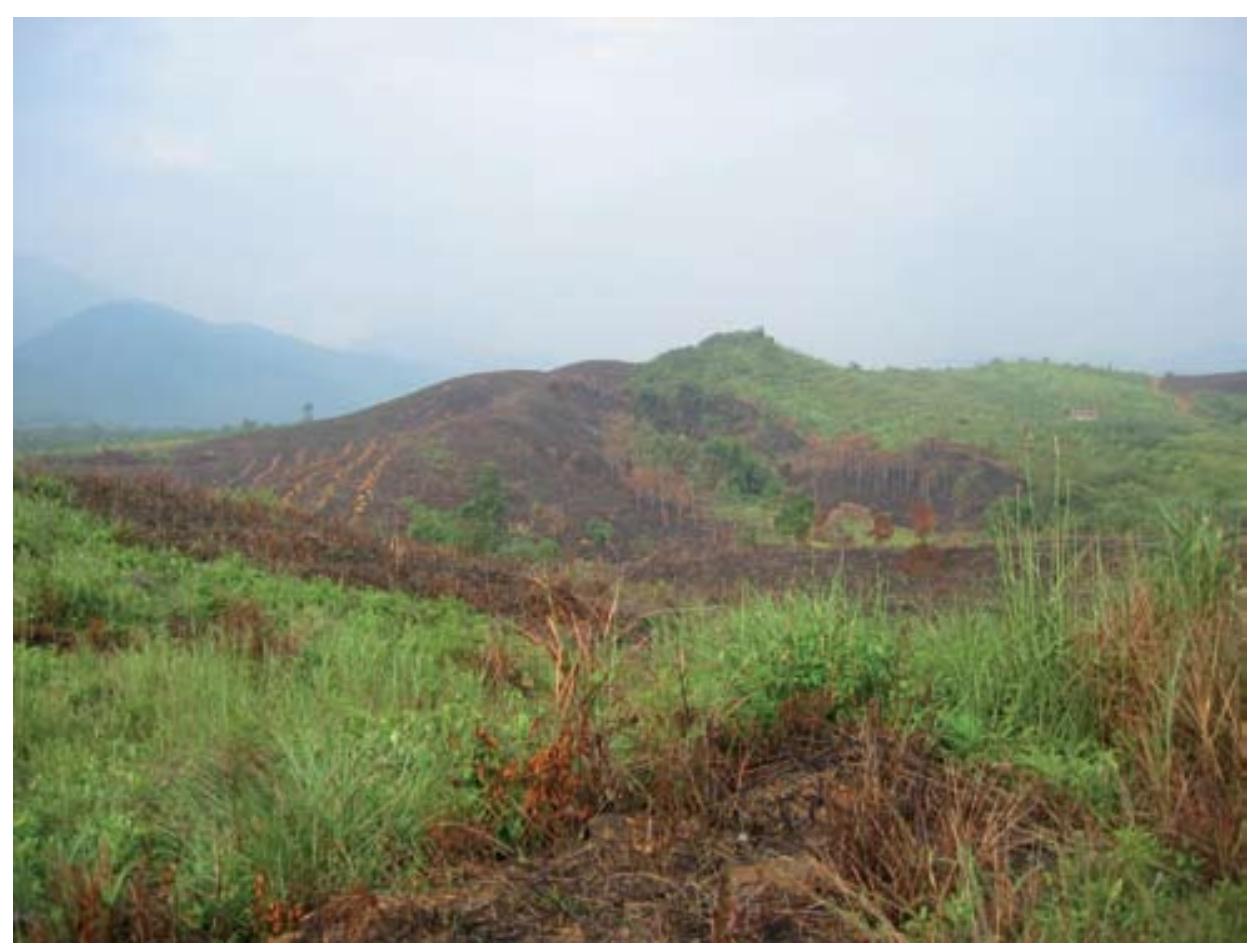

Figure 7. Considerable areas of bare land are used in Khe Tran for new Acacia plantation

Khe Tran landscape mainly reflects the efforts of the central government to manage the local community resettlement and to apply agricultural and forestry programs through land allocation schemes. This mosaic landscape dominates the village area near the settlements. They are situated on alluvial plains, which represent the best land.

The GoV has pursued a land use policy that has greatly influenced the development of Khe Tran. With the objective of creating a natural reserve at Phong 
Dien, the government has encouraged villagers to abandon traditional agriculture and other activities in the mountains for permanent agriculture in the rich lowland soils. The government is omnipresent in the activities of villagers through the Provincial People's Council, which frequently intervenes at the local level. The people's council of the Phong My commune is involved in all decision-making concerning daily village management, nominates the village chief and decides the attribution of government-financed development projects.

Our informers said that they did no longer hunt in the forest because there is little game and hunting is banned by the government. This said, when shown a map, they can tell where to find the different wild animals, which shows that they have only recently given up hunting or that some clandestine hunting (mostly by snares as firearms are illegal) still occurs.

An old cemetery is situated in the middle of an Acacia plantation, and the remains of abandoned villages can be found around the small tree forest in the village area. These land features represent important historical and cultural sites for the villagers.

\subsubsection{Distribution of resource and land types (participatory resource mapping)}

As mentioned previously (see Methods, Chapter 2), community meetings were used to map the main resources and land types identified by villagers. These participatory mappings are a preliminary condition to arrive at a common understanding of the local perceptions of the different land types and activities in the target area.

During the participatory mapping exercise, we provided a basic map showing the main rivers and tributaries, roads and village location. Local representatives added the spatial distribution of many land types and resources, e.g. forests, Acacia and rubber plantation, agricultural land, settlements and home gardens, old village, specific locations for hunting and other specific resources such as war wreckage, rattan, bear, pheasants, etc. The final result of this map can be seen in Figure 8 .

Villagers showed good knowledge of the resources near their settlement, including resources from home gardens, agriculture land, plantation forests, small tree forests, bare hills and rivers. Most of the villagers seem to have limited knowledge of the resources situated farther from the village, e.g. in the big tree forest.

Even if the map was not meant to be used for official or legal purposes, villagers considered it a good tool for communication with the outsiders on local land types and resources. The map was used during a workshop with villagers on biodiversity conservation issues in Khe Tran during the last days of our survey (see local perceptions in Chapter 6). The field team also used the map for the selection of relevant sites for measuring plots in the various land types identified by villagers and collecting information on local knowledge of forest products and sites history. 


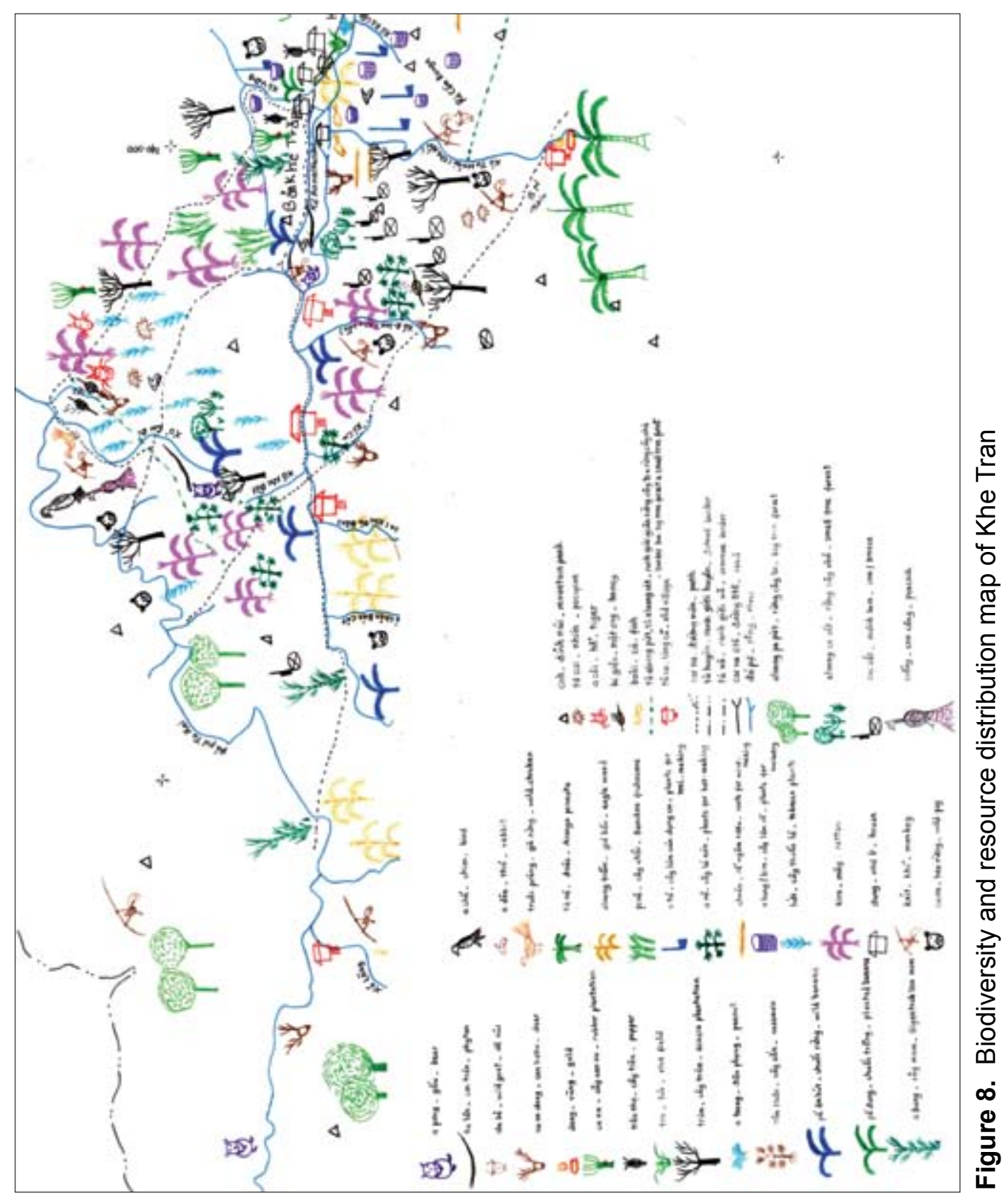


The process of compiling the map showed us that, even if the landscape around Khe Tran is severely disturbed, mainly made up of secondary forests, plantations, grassland and bare lands, villagers recognize a large number of wild resources not far from the village, including some extremely rare animals (tigers, bear). According to informants, these animals were observed at some time during the last 5-6 years.

Therefore, even if the knowledge of resources and land type locations is important, it is concentrated mainly in the village's vicinity. We will return to this map during our discussion on traditional knowledge in the following chapter.

\section{Summary}

The village is characterized by the presence of a strong minority group, the Pahy, mixed with the majority group in Vietnam, the Kinh, and with the Khome. The population of Khe Tran moved during the war against the USA, some to A Luoi district, close to the Laotian border, and some into Laos. At the end of the war, they were authorized to resettle in their village, and in 1992 the government encouraged the villagers to settle near the main road and helped them to develop more sedentary cultivation of rice fields and industrial crops plantations of Acacia and rubber.

Only few people among the 20 households have received no education. Most villagers spend a large amount of time in their gardens, rice fields and plantations. The village is divided in two areas, the upper part, where villagers have smaller incomes and depend on home gardens and Acacia plantations for their livelihoods; and the lower part, with a higher mean income, depending on more diversified crops cultivation, including Acacia and rubber plantations, home gardens and peanut, cassava and rice fields. The 20 households are scattered and it takes about 30 minutes to walk from one end of the village to the other.

Villagers distinguish a large number of land types, some corresponding with the official nomenclature. Of the eight main land types, forests account for three. In addition to big tree forests and small tree forests, villagers include plantations among the forest landscape. This classification may relate to the official 'forest status' of the bare land used for plantation. Plantation forests are part of a large land allocation and forest rehabilitation plan promoted by the local government to provide more income from 'stable' and sedentary activities and to keep the villagers out of more forest-dependant activities (shifting cultivation, timber collection, NTFP collection), especially in the Phong Dien Nature Reserve. Nevertheless, participatory mapping of the natural resources of the village shows that knowledge of forest products, wildlife and other natural resources is still important among the villagers, even if this knowledge tends to be limited to the close vicinity of the village. We did not collect much information on areas situated farther from the village, in the core zone of the Nature Reserve. Villagers also have a strong sense of ownership when discussing land tenure in the village, repartition of plantation responsibilities and expectation in the future. 


\section{Local perceptions of the different land types and resources}

Perceptions of natural resources differ between local people, such as the Pahy, and outsiders such as the government, traders, researchers or development agencies. Decision makers need information on local perspectives to plan and manage the natural resources in a more sustainable way. We present here the villagers' perceptions of their surrounding natural (e.g. forest, river) and other (forest plantation, home garden, etc.) land types and the village's biodiversity.

We captured local perceptions of the surrounding landscape and biodiversity using scoring exercises (PDM), focus group discussions and interviews (as described in Methods, Chapter 2). Some of the results were qualitative concerning the description of the perceptions, others were quantitative to compare the perceptions of different groups of villagers, but always accompanied by explanations on the values given by informants.

Villagers use numerous natural resources in their daily activities. These resources (plants and animals) can be found in the various landscape units identified by the local people. Natural resources are used for food, medicine, construction, basketry, firewood, cash earning, etc. The following results show how and why these resources are meaningful for local people in Khe Tran.

\subsection{Local land uses}

As discussed earlier, there are six main land types around Khe Tran (Table 5, page 25). Bare land, river, big tree forest and small tree forest represent the natural land types, while garden, forest plantation, rice field and dry land for agriculture are the direct consequence of villagers' activities, sometimes with support from the local government. During the community meetings, villagers named some areas allocated by the government for agriculture and plantations in a highly formal way, e.g. 'allocated land for rubber plantation', or, in Pahy, 'cutect cao su, in contrast with more basic land type, e.g. 'small tree forest' (along papút). 
According to the villagers biodiversity is important for their livelihoods. Table 6 shows some important products that local people still gather exclusively from the natural forest. Hundreds of other products (plant and animal) are still collected during their daily activities in the surrounding landscape. In Section 6.6, we discuss in more detail the most important products from forest.

More complete, although not exhaustive, lists are also available in Annexes 1 and 2, which show the important knowledge of local people on biodiversity and the large range of uses they have for many forest products. During discussions, informants agreed to categorize the main uses of these products into 14 big categories (Table 7) adapted from the MLA method to the local context.

Table 6. Important forest plants and their local uses

\begin{tabular}{|l|l|}
\hline Product names (Pahy or Vietnamese/scientific) & Uses \\
\hline A ro/Licuala spinosa & Conical hat \\
\hline Áp lăng/_ & Roof \\
\hline Cây re/Calamus walkeri & Furniture \\
\hline Chùn quét/_- & Broom \\
\hline Long huện/Tarrietia javanica & Cattle cage \\
\hline Tu vien/Melocalamus compactiflorus & Rope \\
\hline Tân ning/- & Honey \\
\hline Ùi a dúm/- & Firewood \\
\hline
\end{tabular}

Table 7. Main categories of use of plant and animal resources

\begin{tabular}{|c|c|}
\hline Categories of use & Description \\
\hline Basketry & Rope made from leaves, rattan or bark for weaving or tying \\
\hline Firewood & Wood for fire \\
\hline Fodder & Used for feeding cattle, pigs \\
\hline Food & Primary and secondary foods, famine food \\
\hline Heavy construction & Material for permanent construction (houses and bridges) \\
\hline Hunting function & $\begin{array}{l}\text { Poisons, bait, gums, catapult made of plant/animal parts } \\
\text { used to catch animal }\end{array}$ \\
\hline Hunting place & $\begin{array}{l}\text { Indirect use of plant as hunting location, usually fruits } \\
\text { appreciated by game }\end{array}$ \\
\hline Light construction & Poles and cuttings for cattle cage, fences, furniture \\
\hline Marketable items & $\begin{array}{l}\text { Plant/animal parts and processed products that are sold for } \\
\text { cash }\end{array}$ \\
\hline Medicine & Medicinal and health related \\
\hline Ornamental/traditional/ritual & $\begin{array}{l}\text { Plant/animal parts used in ceremony, dress, decoration, } \\
\text { house ornaments }\end{array}$ \\
\hline Recreation & Area or forest products used for entertainment needs \\
\hline The future & Plant/animal invested and will be important in the future \\
\hline Tools & $\begin{array}{l}\text { Plant/animal parts used for tools in agriculture, housing; } \\
\text { includes rice pounders, ploughs, tool handles, etc. }\end{array}$ \\
\hline
\end{tabular}




\subsection{Land type importance}

The results from the scoring exercise with men and women groups show that villagers consider forest the most important land type (40\% and 35\%; Figure 9). Both natural and plantation forests are important to villagers because they provide many products for the local livelihoods such as latex, timber, rattan, firewood, honey, medicinal plants, bamboo, food, etc. Natural forests also have the role of protection of the village against floods and erosion. Villagers consider gardens the second most important land type, especially for those who live on the upper part of the village, because gardens provide fodder, bamboo for fences for cattle and fruits for cash income. They consider rice fields the least important because they belong to only those who live in the lower part of the village and because rice is a recently cultivated crop here that can be substituted by cassava or peanut. People who do not have rice fields buy rice from the local market at Phong My commune, not far from the village.

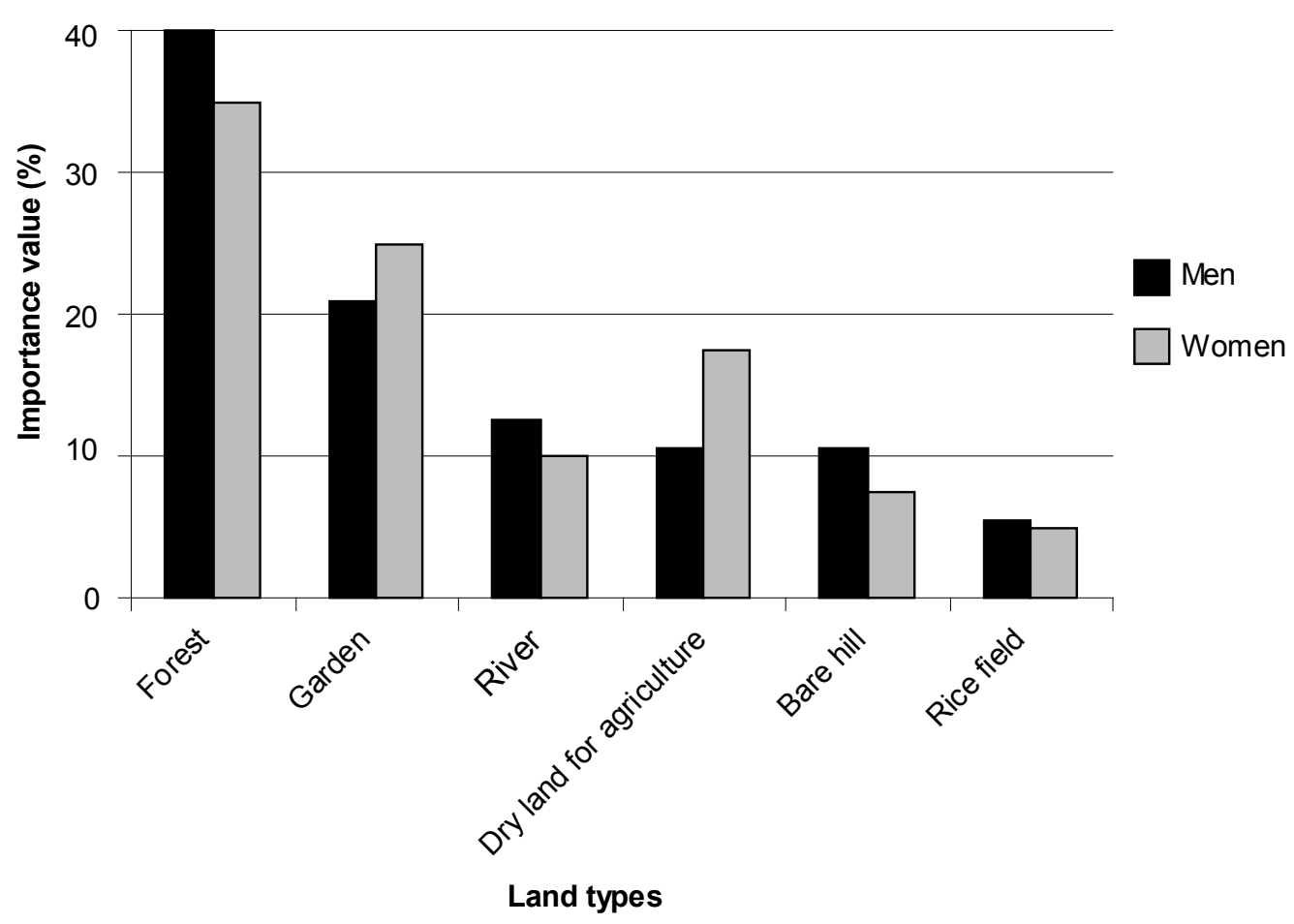

Figure 9. Land type by importance (all groups)

The high importance villagers place on forest is explained by the products sold and by the contribution to the local livelihoods that forest can provide. Forest will support the villagers' livelihoods in the future too (Table 8, page 33). Rice fields provide only few uses such as food for humans and cattle. Cattle are often let free in the rice fields once the harvest is completed. 
Gardens and forests are important for the future because they can provide consequent income. Bare land comes in third position for its use in the future because it will provide lands for new forest plantations. Forest dominates all but four of the use categories (Table 8). Bare lands are the most important land types for fodder, and gardens for food. Gardens and the riverside are equally important as hunting places, and they represent the places where villagers spend a large amount of their time. The main game hunted is small birds in the vicinity of the village. River is important for recreation because villagers regularly go to swim and wash in the nearby river, and children go there to play.

\subsection{Forest importance}

Villagers divide forest land type into three categories, namely big tree forest (primary forest), small tree forest (young, secondary regrowth) and plantation forest. Men and women have different points of view concerning the importance of these forest types. Men consider plantation the most important forest type (49\%; Figure 10), because they reckon that in the future plantations will provide them with more regular cash income. Big tree forest comes in second place $(43 \%)$, although villagers said they gather more products there than in the other forest types. One reason for the lower importance given is the difficult accessibility of these forests.

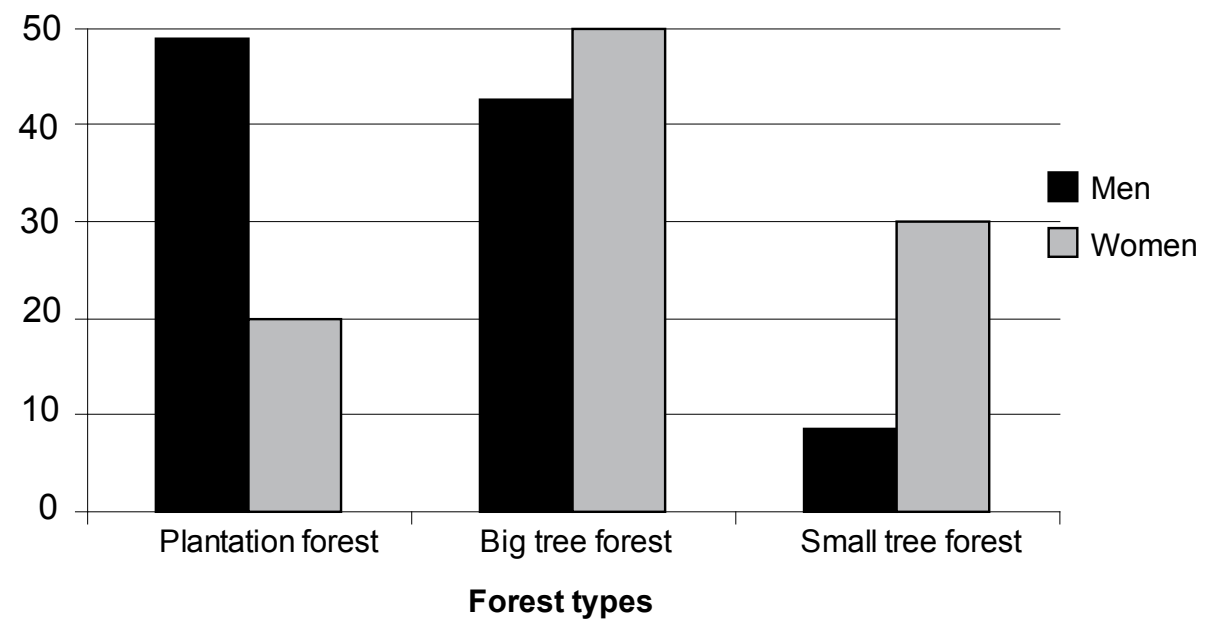

Figure 10. Importance of forest types (all groups)

Women consider the big tree forest the most important type (50\%). They explain that big tree forest provides many valuable products to them. Uses of these products includes food, medicine, heavy construction, tools, basketry, ornaments and marketable items (Table 9). Women also often go to the forest to collect leaves to make conical hats. 

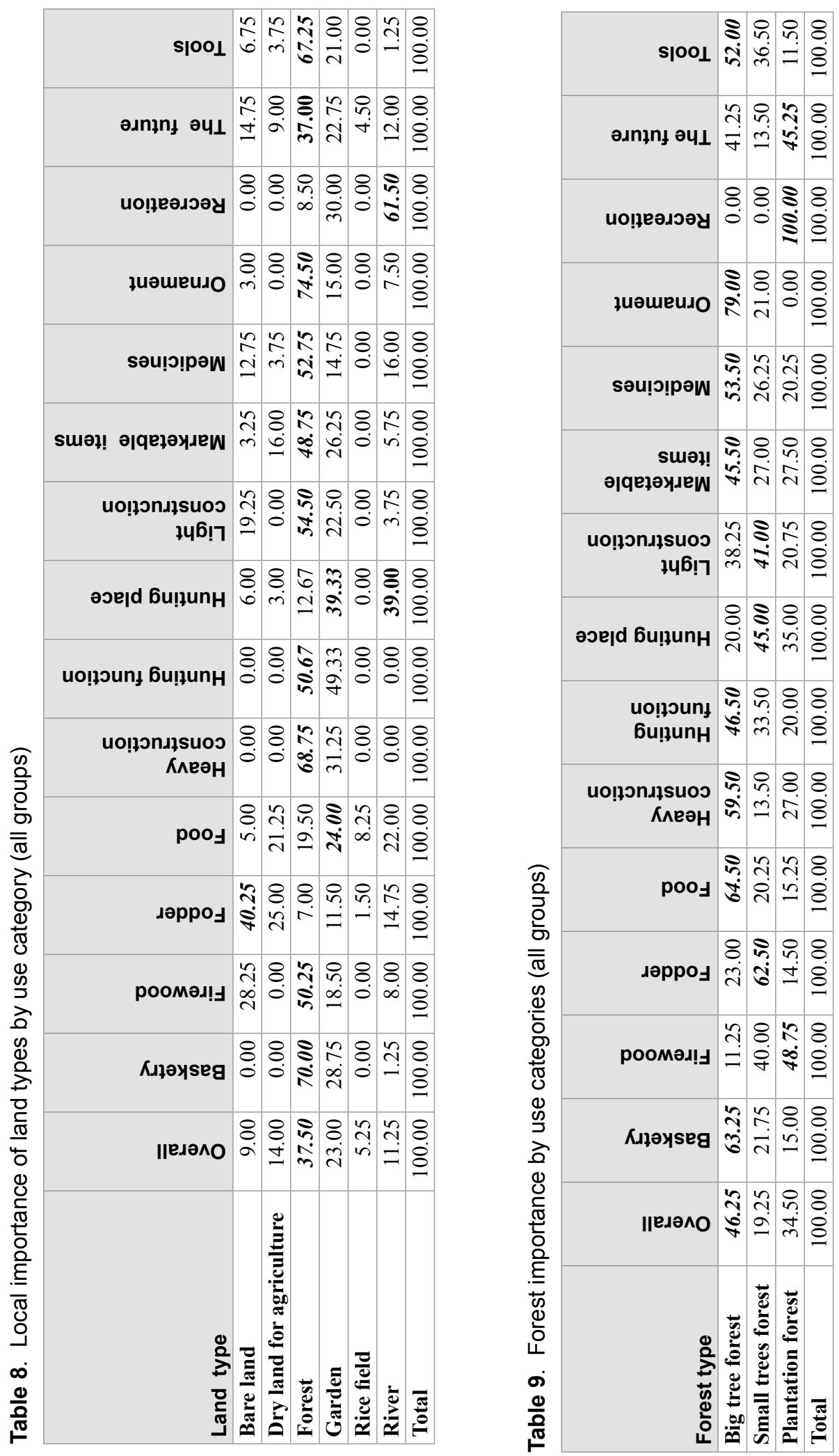
Men do not consider the small tree forests important. They are mostly used for fodder extraction and for hunting. We will see in the section on ethno-botanical knowledge, Chapter 8, that a large number of herbaceous plants are recognized for their use as fodder. Usually, villagers find food for their cattle in the grasslands near the village, rather than in the forest, but this result shows that their knowledge is focused on this kind of activity and that their perception has followed their progressive settling process. In these forest areas, they also gather small materials for tools and cattle fences. On the contrary, women consider this forest type the second most important. According to them, because small tree forests are closer to the village, it is easier for them to collect grass for cattle, tool materials and firewood. The results show that resource accessibility and the differing activities by gender play an important role in the difference of perception by the villagers.

The results of group discussions show that plantation forests have not brought optimal benefits yet, as plantations are still recent, but in the near future they will become the most profitable source of income. This point seems to relate to the fact that plantations are the key element of the government policy for the settling process. Government officials emphasize that plantations bring more income and a better livelihood to local people than shifting cultivation, and for that reason villagers should stay close to the main road and reduce their activities in the forest. But local perception shows a different perspective on the importance of natural and planted forests to local livelihoods.

In the context of nature reserve management, the Khe Tran community needs alternative sources of income to replace the loss of products previously provided by the forest (marketable items, construction materials, tools, etc.). There should be an agreement on the possibility of access to the forest during hard times (drought or flood). Perception of forests should be considered in its dynamic aspects, however, and the importance of forests to local people may change with time.

\subsection{Forest importance in the past, present and future}

The notion of forest importance across different time scales was difficult to explain during group discussions. Groups had to compare the importance of forest (both natural and plantation) among three time periods (present, 30 years ago and the next 20 years) based on the different categories of uses, but to avoid confusion the category 'for the future' was not used.

The result shows that forest of 30 years ago was more important for villagers than that of today (Figure 11). According to local informants, in the past they were more dependent on forest products for food, heavy construction, firewood, basketry, hunting and recreation. Today agriculture (home gardens and plantations) has replaced many previous activities in the forest.

Villagers consider the forest of the future more important than the forest at present. All groups think that it will provide more fodder, more products for ornament and more marketable resources such as latex and timber (Table 10). Each household should have a bigger plantation that is a more important source of 


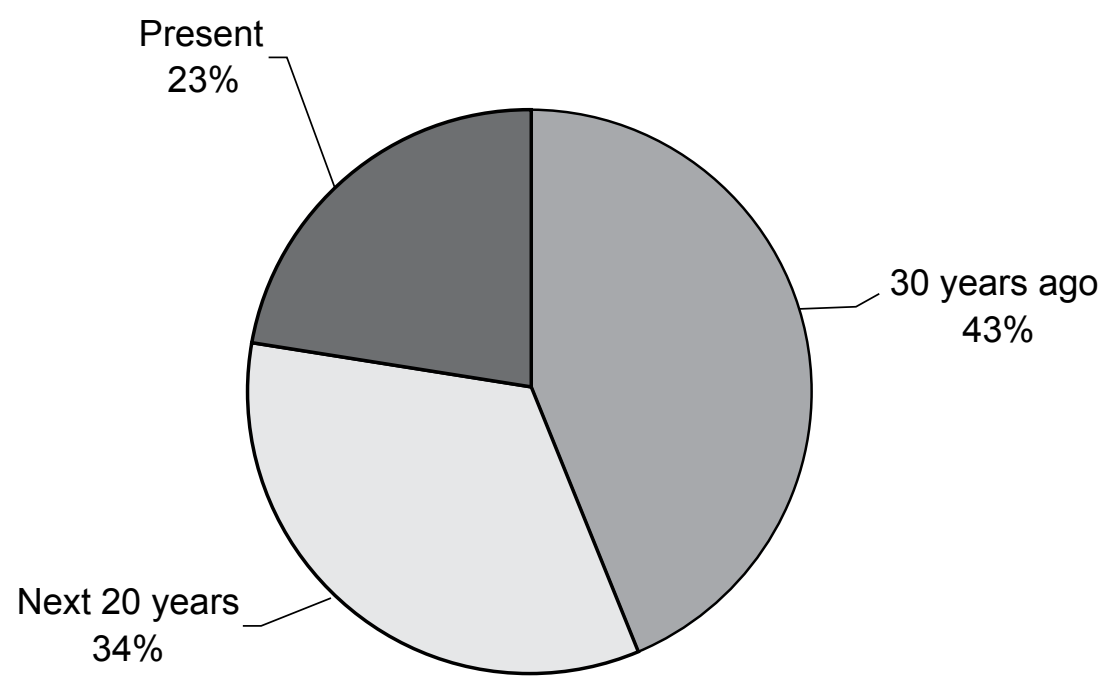

Figure 11. Forest importance over time (all groups)

Table 10. Forest importance over time according to different use categories (all groups)

\begin{tabular}{|l|c|c|c|c|}
\hline Category of use & 30 years ago & Present & Next 20 years & Total \\
\hline Total importance & $\mathbf{4 4 . 0}$ & 22.5 & 33.5 & 100.0 \\
\hline Basketry & $\mathbf{4 3 . 5}$ & 37.0 & 19.5 & 100.0 \\
\hline Firewood & $\mathbf{4 7 . 8}$ & 32.0 & 20.3 & 100.0 \\
\hline Fodder & 17.3 & 36.3 & 46.5 & 100.0 \\
\hline Food & $\mathbf{4 3 . 5}$ & 28.3 & 28.3 & 100.0 \\
\hline Heavy construction & $\mathbf{4 0 . 0}$ & 29.0 & 31.0 & 100.0 \\
\hline Hunting function & $\mathbf{7 5 . 0}$ & 19.3 & 5.7 & 100.0 \\
\hline Hunting place & $\mathbf{7 0 . 0}$ & 20.7 & 9.3 & 100.0 \\
\hline Light construction & 33.0 & $\mathbf{3 9 . 5}$ & 27.5 & 100.0 \\
\hline Marketable items & 22.0 & 31.5 & 46.5 & 100.0 \\
\hline Medicine & 32.5 & 33.0 & 34.5 & 100.0 \\
\hline Ornamental/traditional/ritual & 8.5 & 32.0 & $\mathbf{5 9 . 5}$ & 100.0 \\
\hline Recreation & $\mathbf{5 8 . 0}$ & 0.0 & 42.0 & 100.0 \\
\hline Tools & 36.5 & $\mathbf{3 7 . 8}$ & 25.8 & 100.0 \\
\hline
\end{tabular}

income. The forest of the future will also protect the water source and will prevent the village from floods and erosion. Moreover, forest will be a safety net in case of hard times.

Looking at the results in more detail, we find that for most use categories the forest of the past was the most important, except for fodder, light construction, marketable items, medicine, ornamental and tools. The presence of a protected area, affording limited access to forest resources, partly explains why the forest of the present is the least important one. Another reason is the diversification of subsistence activities, which makes local people rely less on forest products than 
they used to. The growing importance of marketable items in the future comes from the expectation of more Acacia and rubber plantations. Villagers also expect to have more cattle in the future and will rely more on forest resources for feeding it. Justification for the increasing importance of medicinal and ornamental functions of the forest in the future is key to a better understanding of the local perception of the village's development. The future is supposed to bring wealth, education and time. Education will sharpen the local knowledge on medicinal plants and wealth will provide more time to look for ornamental plants in the forest. Villagers told about the possibility of developing an ornamental plants business and were aware of the good possibilities for cash earning, but they are not yet fully using them.

These results also suggest that villagers' dependency on and perception of natural forest importance have been affected by the application of GoV programs such as the Phong Dien Nature Reserve management and forest rehabilitation. Reserve management has stopped people from looking for forest products. The consequence is that natural forest has become less important to villagers. Plantation forest, being part of the rehabilitation program and a relatively new activity in Khe Tran, has an increasing importance and is replacing natural forests in that function. Villagers expect to be granted permanent land use certificates (the 'red book') for these planted areas, a way, according to them, to secure their rights.

The source of products is also important to understand the local dependency on domestic or wild products.

\subsection{Importance according to source of products}

Villagers use a large number of plants and animals in their daily lives. To better understand the importance of the different products we categorize them into three sources: wild, cultivated/farmed and purchased.

Villagers perceive domesticated products as the most important source for both plant and animal products (Figure 12). The villagers cultivate plants (pepper, peanut, cassava, rice, jackfruit, bamboo) as well as grow animals (cattle, chickens, pigs). They use these products mainly for domestic use and for cash earning. Although the villagers still depend on wild products, they focus more on maintaining their farming and plantation systems. Wild products from the natural forest (mostly plants) are still collected, but, as villagers are not allowed to hunt animals or cut trees in the natural forest of the conservation area, they usually collect wild animals from places close to the village but outside the nature reserve, e.g. gardens, bare lands and forest plantations.

Both men and women groups agree that cultivated plants and farmed animals are the most important sources of products for consumption (Table 11). They explain that these are their most valuable and accessible sources for food and cash. The importance local people give to wild products may be influenced by the fact that free wild resources are limited and often inaccessible because of the ban on extractive activities in the future reserve. 


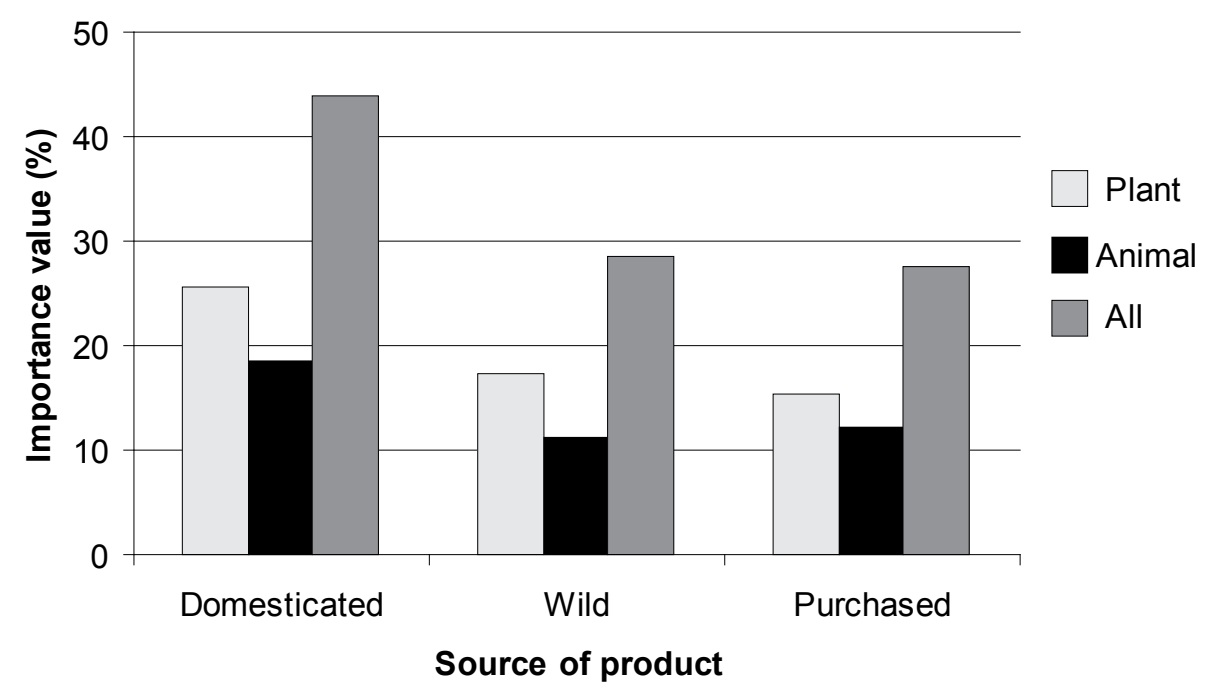

Figure 12. Source of product importance (all groups)

Table 11. Importance (\%) of source of product by gender

\begin{tabular}{|l|r|r|r|r|r|r|r|r|r|}
\hline \multirow{2}{*}{ Gender } & \multicolumn{2}{|c|}{ Wild plants } & \multicolumn{2}{|c|}{ Wild animals } & \multicolumn{2}{c|}{$\begin{array}{c}\text { Cultivated/ } \\
\text { farmed }\end{array}$} & \multicolumn{2}{c|}{ Purchased } & \multirow{2}{*}{ forest } \\
\cline { 2 - 10 } & $\begin{array}{c}\text { non } \\
\text { forest }\end{array}$ & forest & $\begin{array}{c}\text { non } \\
\text { forest }\end{array}$ & plant & animal & plant & animal & Total \\
\hline Women & 8.00 & 7.00 & 4.00 & 6.50 & $\mathbf{2 5 . 0 0}$ & 19.00 & 17.00 & 13.50 & 100.00 \\
\hline Men & 13.00 & 6.50 & 6.50 & 5.50 & $\mathbf{2 6 . 0 0}$ & 18.00 & 13.50 & 11.00 & 100.00 \\
\hline Mean & 10.50 & 6.75 & 5.25 & 6.00 & $\mathbf{2 5 . 5 0}$ & 18.50 & 15.25 & 12.25 & 100.00 \\
\hline
\end{tabular}

\subsection{Most important products from the forest}

Forest is the most important land type according to the local people partly because of the products it supplies. Here we show how the forest (both natural and plantation) provides people with products and which are the most important plants and animals.

Figure 13 shows that forests are considered most important in providing for a better future (20\%) and for food (11\%), marketable items (11\%), fodder $(10 \%)$, heavy construction $(10 \%)$ and tools $(10 \%)$. These values were calculated from a general consideration of the uses of forest types, the first step during the scoring exercises, when groups of villagers estimate the overall importance of forest resources. 


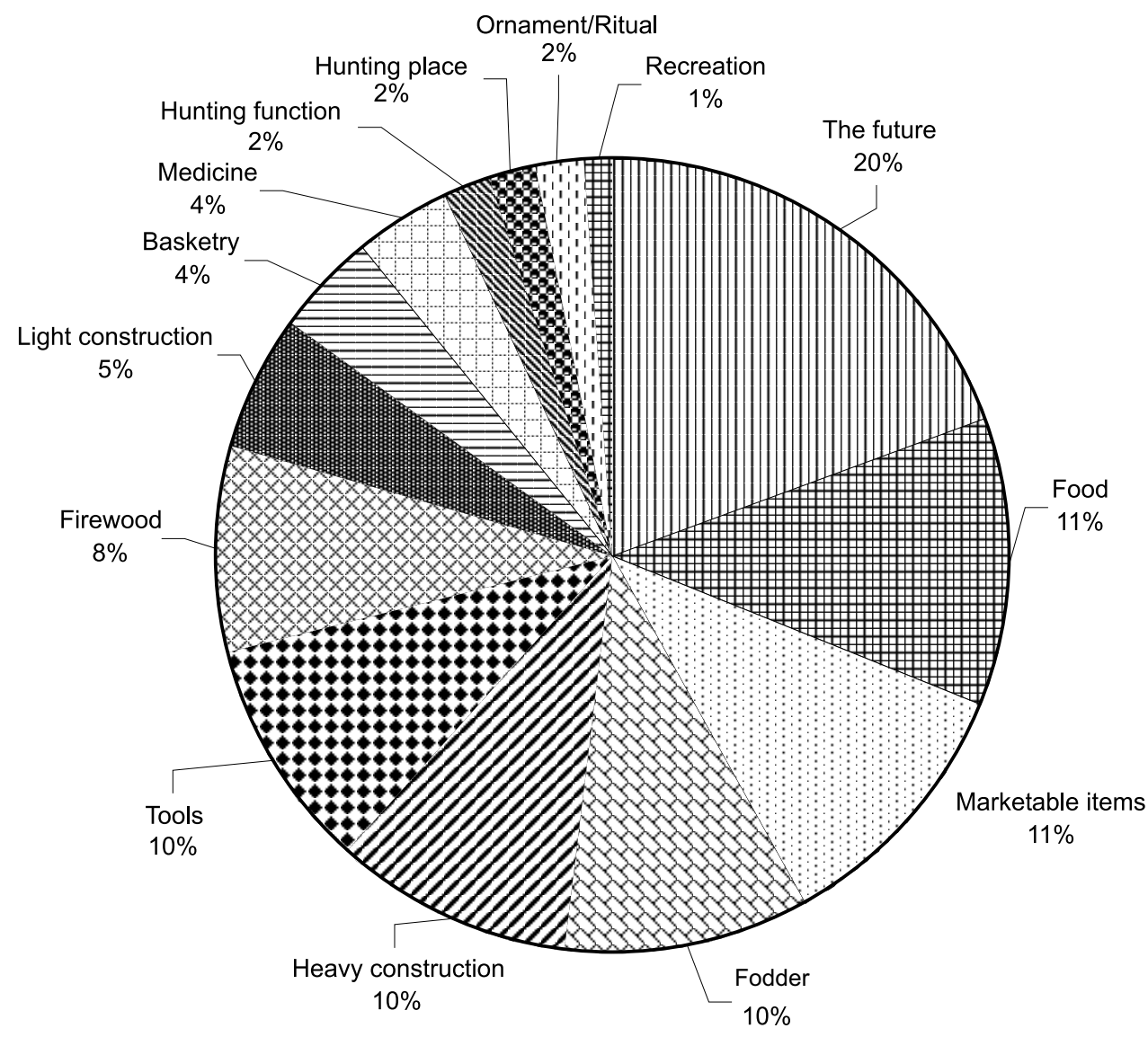

Figure 13. Importance of forest resources by use categories (all groups)

A second activity was to assess the importance of the 10 main species for each category of use. Informants listed and scored the most important plant and animal species they gather from the forest. A list was made for each of the categories of use except hunting place, recreation and the future. Villagers decided not to include these latter categories because no specific plant or animal from the forest was used for them. The result shows that local people consider forest important for the future, but cannot name any specific plant or animal to support this assumption. This emphasizes the fact that specific knowledge on forest has decreased. Local people still recognize the various roles of forest in general, but have difficulty to provide information on more specific resources.

The scores of the important species from the forest were analysed, and the top 10 most important plants and animals were identified using a tool called LUVI (Local User Value Index; Sheil et al. 2003), which represents the sum of all a species values. A summary of the results is shown in Table 12.

The importance of plants seems correlated to their usefulness (number of use categories). Bamboo (Pheo), the most important plant in Khe Tran, is used for 
Table 12. Most important forest plants and animals in Khe Tran (all groups)

\begin{tabular}{|l|l|r|l|r|}
\hline \multicolumn{3}{|c}{ Plant } & \multicolumn{2}{c|}{ Animal } \\
\hline Pahy & Latin/English & LUVI & Pahy/English & LUVI \\
\hline Pheo & Poaceae/bamboo & 24.22 & A binh/rat & 7.81 \\
\hline Ki re & Calamus walkeri /rattan & 20.49 & Chon den/_- & 3.67 \\
\hline Tràm & Acacia auriculiformis/Acacia & 19.21 & A cuot/frog & 3.55 \\
\hline Pe & Musaceae/banana & 12.87 & A at na/- & 2.35 \\
\hline A xop & Wendlandia glabrata/tree & 12.28 & Khuou/bird & 1.87 \\
\hline A ro & Licuala spinosa/Licuala palm & 11.96 & A ut/- & 1.75 \\
\hline Huen & Tarrietia javanica/tree & 11.06 & Truoi/chicken & 1.63 \\
\hline Pa lar & Cleistanthus aff. myrianthus/tree & 10.41 & Chim Cuong/peacock & 1.22 \\
\hline Tu vien & $\begin{array}{l}\text { Melocalamus compactiflorus/ } \\
\text { scrambling bamboo }\end{array}$ & 9.82 & Hon/- & 1.21 \\
\hline Lim & Afzelia xylocarpa/Macka wood & 9.03 & Pi reo/- & 1.15 \\
\hline
\end{tabular}

food (bamboo shoots), in construction and as fodder (Table 13). It can also be sold to the chopstick industry and provide villagers with cash income. This valuable plant is available in nearby forests, especially on the riverside, where people grow it near their settlement.

Another important resource, rattan is used for making ropes and baskets, but it is also sold to the furniture industry. Villagers still regularly go into the forest to look for rattan, which is then transported to the village by river. The FPD tolerates this activity even near conservation areas, as it provides income to local people without disturbing the natural forest too much. Acacia is valued for its economic importance, and banana for food (and sometimes as commodity sold among villagers).

Macka wood (Lim) was the tenth most important plant. The wood from this tree has two specific uses: heavy construction and tools. Many other plants, such as Pheo, Huen, A xop, and Tràm, have the same uses, but Lim is one of the best. It seems that the importance of plants, especially plants from natural forest, for heavy construction is decreasing because people are not allowed to cut trees in the nature reserve. Some villagers explained that they had planted forest trees in their yard to satisfy some of their log needs, as otherwise they would have to buy expensive planks and posts for the construction of their houses.

No plant is used for the three categories of hunting place, recreation and the future, but several of the top 10 plants can share the same uses, such as for tools or marketable items. No plant has just one use, and Lim is the only one to have just two uses.

A type of rat, $A$ binh is considered the most important animal from the forest. It is important for food, as it is easy to catch. We were able to find only the Pahy names for most of the animals, as we could not observe them directly. Animals have only four different uses, according to the villagers: the main one is for food, then ornaments, medicine and cash earning (Table 14). 
Table 13. Most important forest plants by categories of use (all groups)

\begin{tabular}{|c|c|c|c|c|c|c|c|c|c|c|c|c|c|c|c|}
\hline $\begin{array}{l}\text { Pahy } \\
\text { name }\end{array}$ & Scientific name & 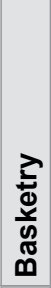 & 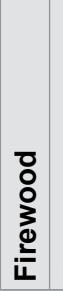 & $\begin{array}{l}\frac{1}{0} \\
\frac{0}{0} \\
\text { 인 }\end{array}$ & 음 & 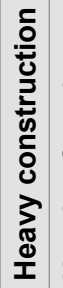 & 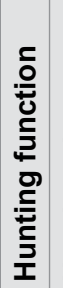 & 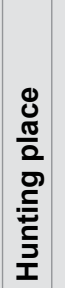 & 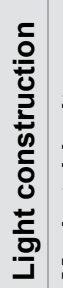 & 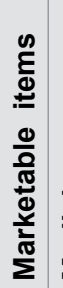 & 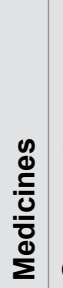 & 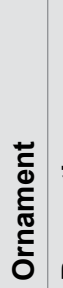 & 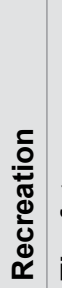 & 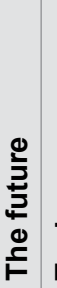 & $\frac{\infty}{0}$ \\
\hline Pheo & Poaceae & & & & & & & & & & & & & & \\
\hline Ki re & Calamus walkeri & & & & & & & & & & & & & & \\
\hline Tràm & Acacia auriculiformis & & & & & & & & & & & & & & \\
\hline$P e$ & Musaceae & & & & & & & & & & & & & & \\
\hline A xоp & Wendlandia glabrata & & & & & & & & & & & & & & \\
\hline A ro & Licuala spinosa & & & & & & & & & & & & & & \\
\hline Huen & Tarrietia javanica & & & & & & & & & & & & & & \\
\hline Pa lar & Cleistanthus aff. myrianthus & & & & & & & & & & & & & & \\
\hline Tu vien & Melocalamus compactiflorus & & & & & & & & & & & & & & \\
\hline Lim & Afzelia xylocarpa & & & & & & & & & & & & & & \\
\hline
\end{tabular}

Table 14. Most important forest animals by categories of use (all groups)

\begin{tabular}{|c|c|c|c|c|c|c|c|c|c|c|c|c|c|c|}
\hline Animal (Pahy) & 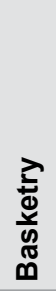 & 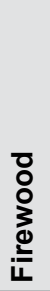 & 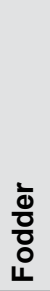 & $\begin{array}{l}\text { 운 } \\
\text { 인 }\end{array}$ & 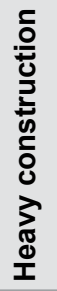 & 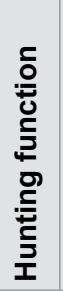 & 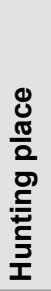 & 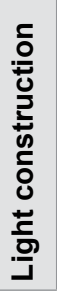 & 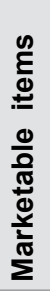 & 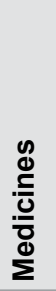 & 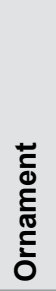 & 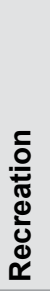 & 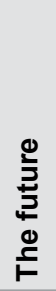 & $\begin{array}{l}\frac{0}{0} \\
\stackrel{0}{\circ}\end{array}$ \\
\hline A binh & & & & & & & & & & & & & & \\
\hline Chon den & & & & & & & & & & & & & & \\
\hline A cuot & & & & & & & & & & & & & & \\
\hline A at na & & & & & & & & & & & & & & \\
\hline Khиои & & & & & & & & & & & & & & \\
\hline Aut & & & & & & & & & & & & & & \\
\hline Truoi & & & & & & & & & & & & & & \\
\hline Chim cuong & & & & & & & & & & & & & & \\
\hline Hon & & & & & & & & & & & & & & \\
\hline Pi reo & & & & & & & & & & & & & & \\
\hline
\end{tabular}

People have valuable knowledge on local biodiversity of natural resources found near the village and those that can be linked to activities important for their livelihoods (e.g. knowledge on plants used as fodder is important in all the land types). The species recognised and assessed cover both rare and abundant 
resources, as well as cheap and expensive products. For example, Macka wood ( $\mathrm{Lim}$ ) is a useful plant for tools and construction materials in Khe Tran but it is also listed in the World Conservation Union's (IUCN) World List of Threatened Trees, and is more generally known as a valuable commercial timber (Table 15).

Local knowledge can be used to better understand conservation priorities for plants and animals. We learned that local people can provide much information on species' abundance, distribution and other biodiversity parameters. It would also be useful to involve local people more closely in the biodiversity management of the future nature reserve. Their familiarity with the area and their perception of the forest would be a valuable contribution to the conservation of the area.

Table 15. Locally important plant species by use category and IUCN list of threatened trees

\begin{tabular}{|l|l|l|l|}
\hline $\begin{array}{l}\text { Pahy } \\
\text { name }\end{array}$ & Scientific name & Local uses & IUCN Red List category \\
\hline Lim & Afzelia xylocarpa & Tools, construction material & Endangered \\
\hline Sao & Hopea odorata & Marketable items & Vulnerable \\
\hline Prao & Parashorea stellata & Construction material & Critically endangered \\
\hline A ngo & Pinus latteri & Marketable items & $\begin{array}{l}\text { Near threatened/almost } \\
\text { vulnerable }\end{array}$ \\
\hline
\end{tabular}

\subsection{Threats to local forests and biodiversity}

People in Khe Tran have a long history of living near forests and managing them for their livelihoods. They have accumulated experiences and knowledge on local forests and biodiversity conditions. It is important to understand and acknowledge this wisdom when planning future management activities appropriate for the reserve.

When asked about threats to the local forest and biodiversity, informants gave various answers. The diversity of results indicates that the nature of recognized threats is highly related to the informant's location (lower or upper part of the village) and to individual experience.

Timber felling was the main threat identified by villagers (17 of 19 respondents; Table 16). The GoV declared logging forbidden in 2000, following the establishment of an investment plan for Phong Dien Nature Reserve. Even if the reserve status is not yet official (it will be in 2010), the government is already taking action to protect the forests of the future conservation area. Villagers consider that logging may destroy the forest, and it is a sensitive issue because, while the villagers are banned from logging, they have no right to stop outsiders from collecting timber in the area. Villagers have no rights with respect to forest management, and they would like this situation to change (see following section).

Forest fire is considered a threat because fire is often used for war wreckage and honey collection or caused by careless cigarette smoking and (in the past) clearing land for agriculture. To collect scrap metal in grasslands people use metal 
Table 16. Villagers' perception on threats to forest and biodiversity (19 respondents)

\begin{tabular}{|l|c|}
\hline Threat to forests and biodiversity & $\begin{array}{c}\text { Number of respondents } \\
\text { perceiving threat }\end{array}$ \\
\hline Logging & $\mathbf{1 7}$ \\
\hline Forest fire & 8 \\
\hline Slash-and-burn agriculture & 6 \\
\hline War wreckage collection & 6 \\
\hline Hunting & 4 \\
\hline Extraction of forest products & 3 \\
\hline Firewood collection & 1 \\
\hline
\end{tabular}

detectors and because it is difficult to use them on this kind of land, they clear the grass with fire. When this is done during the dry season, the danger is high for the fire to expand out of control.

People think that hunting activities can harm the forest's wildlife. Although hunting is forbidden, villagers often meet poachers in the forest looking for endangered species (bear, tiger). The collection of firewood and other NTFPs is considered less harmful to the forest habitats.

People's knowledge and perception of the threats to forest and biodiversity are similar to those reported by Le Trong Trai et al. (2001), even if we found that the ranks attributed to those threats are quite different. For example, the Le Trong Trai et al. (2001) affirm that Khe Tran people perceive NTFP collection and timber cutting as the most pernicious ongoing threat to the forest, but our survey shows local people rank logging and forest fire as the most serious threats. To some extent, the discourses of local people may be influenced by the official vision and discourse on threats. Villagers try to follow the communal, district and provincial rules as much as possible and this effort may influence their perception of land management. We think that this behaviour helps villagers to emphasize the struggle for their rights over the lands around Khe Tran.

These factors, according to villagers, in addition to the 'open access' to the forest for outsiders (because of limited FPD personnel to control access) have increased the threat to local biodiversity. Local people's involvement in the management of the reserve could be a way to reduce some of the threats. During one of the meetings some villagers expressed their interest to become more directly involved in the management of the surrounding natural forest and they hoped that it might bring them some benefits, e.g. employment and even some timber for their daily needs. If they were to become part of the nature reserve management, it could help achieve a win-win situation.

\subsection{People's hopes for the future of their forest and life}

Villagers gave many answers to our questions on the future of their forest and life during personal interviews. Their aspirations are presented in Tables 17 and 18 .

The main answer given by villagers asked what they would do if the forest degraded or disappeared is to reforest the area. They think they will always 
Table 17. Villagers' perception about forest loss (19 respondents)

\begin{tabular}{|l|c|}
\hline What to do after forest is lost & $\begin{array}{c}\text { Number of respondents choosing } \\
\text { measure }\end{array}$ \\
\hline Reforestation & $\mathbf{8}$ \\
\hline Expand agricultural land & 3 \\
\hline Expand forest plantation & 3 \\
\hline Improve livestock & 2 \\
\hline Nothing but sadness and regret & 2 \\
\hline Prepare to face flood and storm & 2 \\
\hline Expand home garden & 1 \\
\hline
\end{tabular}

Table 18. Villagers' ideas on threats to human life (19 respondents)

\begin{tabular}{|l|c|}
\hline Threats to human life & $\begin{array}{c}\text { Number of respondents perceiving } \\
\text { threat }\end{array}$ \\
\hline Disease & $\mathbf{1 4}$ \\
\hline Natural hazard & $\mathbf{1 1}$ \\
\hline Poverty & $\mathbf{1 1}$ \\
\hline Lack of knowledge & 3 \\
\hline Lack of transport infrastructure & 2 \\
\hline Land mines & 2 \\
\hline Pests of agricultural plants & 2 \\
\hline Lack of communication facilities & 1 \\
\hline Unemployment & 1 \\
\hline War & 1 \\
\hline
\end{tabular}

need forest to protect them from floods and storms. They believe that the effect of natural disasters is often increased by the absence of forest on the hills. The idea to reforest the area reflects villagers' familiarity with forest rehabilitation. The government project of Acacia plantation is well accepted in Khe Tran and successfully implemented in the main bare land areas.

Some of the villagers think they would develop more agricultural and farming activities, forest plantations on cleared forest land, expecting more income from these activities. A few of them said they would just be sad because of the floods in case of forest loss. Other villagers considered the option of preparing ample livestock and cash reserves to face the hazards. Local people generally believe natural forests can protect them from natural hazards, and this opinion is emphasized by those who have experienced disasters during the past.

Villagers identified many threats to human life, but the main factors were disease, poverty/hunger and natural hazards (flood, storm and drought, Figure 14). The lack of knowledge on cultivation and plantation techniques is also considered a threat, because it would cause failures in harvest and provoke starvation (Table 18).

Local people explain that they would work harder to face these threats and would ask for help from the government, which shows their high reliance on government support and guidance. They expect their children to have better 


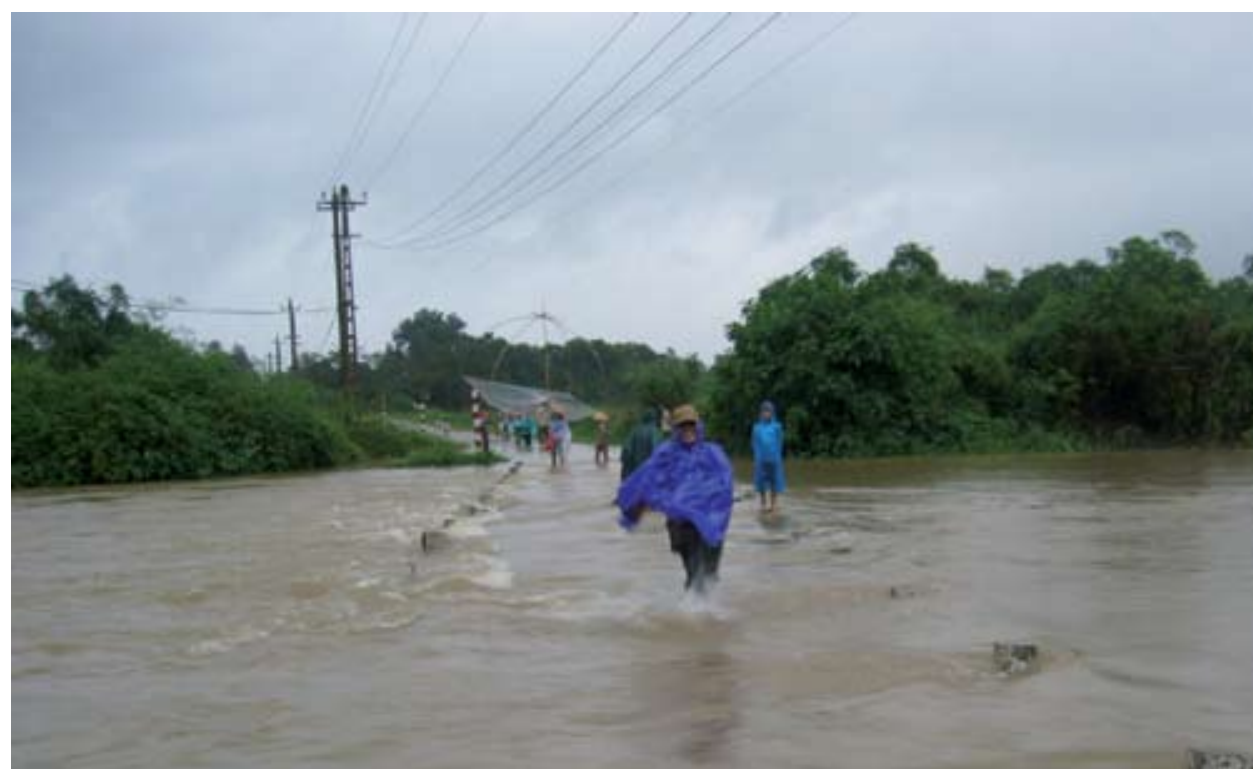

Figure 14. Recent flood on a bridge between Phong My and Khe Tran

education opportunities and to receive training on cultivation techniques and land management. They also expect to earn more money, build stronger houses, yield more agricultural products, and plant more trees to prevent hunger and diseases.

It seems that people will use any possible way to prevent and overcome those threats. Plantation, agriculture and livestock are considered important activities to be intensified. 


\section{Summary}

The natural resources from the various land types in Khe Tran provide important products for local livelihoods. Forest, including natural forest and plantations, is the most important land type for all the villagers because of all the products that can be collected from it. Rice fields are the least important land type, as very few are being cultivated because of the inappropriate soil. An important category of use is fodder, mainly found on bare lands.

Perception on forests types differ by informant gender and according to the accessibility of the resource and the different activities. Plantation is the most important category for men, because of its economic benefits. Among women big tree forest ranks first, because of the diversity of NTFP they collect from it. Because of its relatively recent development, villagers do not consider plantation an optimal activity from which to get full benefits. Plantation is the alternative to forest extractive activities proposed by the government, but it should not be the only one, as the profitability of plantation products depends on fluctuating market condition.

The importance of forest on different time scales is changing for local people. Forest in the present is the least important category, because of the depletion of resources, the government ban on all natural resource collection in the forest, and the actual alternative activities. Forest of the past is considered the most important one for all the activities that were carried out there. Forest of the future is more important than that of the present time because of the belief that plantation forest will bring more income.

Domesticated resources are considered more important than wild and purchased resources. Dependency on forest resources has been affected by the government policy on the PDNR.

When asked what is most important in general, among all use categories, local people consider the forest resources of the future most important, followed by food and marketable item. Local expectations on what forest could provide in the future is therefore high. But at the same time, when asked concretely about the uses of the 10 main species, the future is no longer mentioned. This shows that the specific knowledge on forest has decreased. Local people still recognize the different roles of the forest in general, but have difficulty to provide information on specific resources. Knowledge is still important for areas near the village, and the familiarity with the area and local perceptions on forest land types would be a valuable contribution for conservation agencies.

The main threat to forests identified by villagers is logging, followed by forest fires. Most of them agreed to reforest an area after natural forest loss so as to protect them from natural hazards. Even if local discourses may, sometimes, follow the official one, this opinion shows awareness of the risks of unsustainable activities for both the forest and local livelihoods. 


\section{Characterization of land types}

Our objective in Chapters 7 and 8 is to report the results from the field team activities, which were based on information provided by the village team. These two types of activities, even though separated, were the result of tight collaboration between all the team members.

\subsection{Sampling of land types}

Small amounts of repetition of particular land types within the 11 plots (Figure 15) restrict the possibilities for statistical analysis and broader generalization but nevertheless the sample serves the purpose of better understanding the valuation and perceptions of landscape based on quantitative data, e.g. species identification. We will make some generalizations throughout the text, such as reporting densities and basal areas per hectare, but we ask the reader to be aware of limitations to broad quantitative characterizations of landscapes and their land type comparisons.

The first plot was established in a 12-year-old rubber plantation, which was created just one year after the resettlement of Khe Tran village. This area does not suffer frequent flooding and it has experienced only minimum disturbance, the most severe impacts being caused by strong winds. Although cattle grazing is officially disallowed, some was evident during the fieldwork. Hunting is also not allowed, and for other activities permission from owners ( 10 households) is needed.

The Acacia plantation was eight years old, which is already the harvesting age in plantations of many similarly fast growing species. When the forest was young, the government prohibited the cutting of trees or branches, along with cattle grazing. Any digging was also forbidden. Nevertheless everyone has free access to the graveyard inside the plantation, which is to be honoured by refraining from hunting in its proximity. In 1983 and 1999, when most of the 


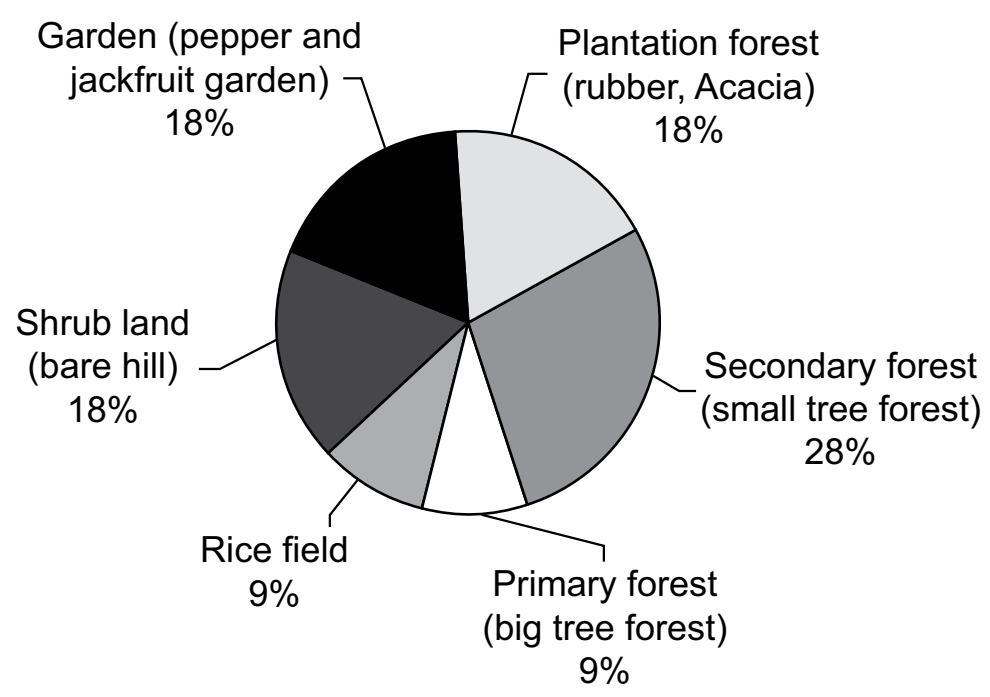

Figure 15. Field sampling of land types in Khe Tran (total sample size 11 plots)

village area was prone to flooding, this area was affected as well. Plantations have also experienced forest fires, especially in 1983.

Most of the secondary forests of the area have experienced disturbance rather recently. One plot (Plot 3) was established in forest that had experienced many fires in the period between 1980 and 1995, and in 1983 a big storm had caused many trees to fall. Earlier this area had also been used for shifting cultivation, and the forest was evaluated to be young, not more than 10 years old. The second secondary forest plot (Plot 9) was in older forest (40 years old) with clearly less disturbance, although it bore some marks of illegal logging. A third plot (Plot 11) was established at a site that had seen some fires in 1983, but the age of the forest was relatively high (40 years) and it was mainly used as a source of firewood and scrap metal.

Two plots were established in gardens with more than 10 years of cultivation history after having been natural forests - one a pepper garden and the other a jackfruit garden with riparian bamboo patches. Both areas had flooded in 1983 and the riparian area had burned. The jackfruit garden had been a small bamboo plantation from 1986 to 1995, and before that it was a mixed banana, pineapple and cassava garden. Cassava and pineapple were still cultivated next to the jackfruit garden, which was presently not intensively managed and thus in close to natural condition with the main trees being jackfruits. In the pepper garden there had been cassava and sweet potato cultivation between 1996 and 2002 and natural forest before that. The rice field was a young fallow between the first harvests at the time of the survey. This area has also been cultivated with peanuts. 
The edge of old growth primary forest is not easily reached by walking from the Khe Tran village. Some of the oldest patches of forest lie close to the mountain tops or on steep slopes reached only after more than one hour's climb and walk. The only plot in mature secondary forest closest to the condition of primary forest was established in 60-to-70-year-old stands visited regularly, but not often, by villagers. Men and women come to this site to collect rattan, honey and metal. The forest was afforded protected status by the provincial government in 1983, and the earlier regular hunting for bear, 'helmeted' hornbills, elephants and porcupines was thus forbidden along with timber production activities.

Shrub lands (or bare hills) are a rather heterogeneous land type category with areas that have a history of having been under sugar cane cultivation (Plot 2) but are now fallows waiting to be converted to production area. Villagers describe those barren areas without any clear function for villagers as being degraded or barren because of the impact of chemicals during the war time (Plot 8).

\subsection{Specimen collection and identification}

A total of 754 plant specimens were collected from 11 plots (Figure 16). In addition to systematic plot sampling of trees and non-trees, the most abundant seedling, sapling, shrub and monocot species were also recorded and sampled separately. In the text all the categories of 'abundant' species refer to this separate census, if not otherwise stated. Table 19 shows the division of specimens in trees, non-trees and abundant species. In total 108 families comprising 260 genera and 439 species were recorded (Annex 3 provides the botanical names, families and local name of specimens collected within and outside the plots). The number of unidentified taxa remains high due to the technical difficulties in sampling as well as the high vascular plant richness of the area.

The sampling was not exhaustive, and was not supposed to be so, as one of the main objectives of using MLA was to test the relevance of such a tool in the Vietnamese context. Nevertheless the sampling using 11 plots in total was considered rigorous and adequate for non-tree representativeness, since the curves of cumulating numbers of non-tree vascular plant species laid against cumulating numbers of random subplots are levelling out for most land types (Figure 17). There was surprisingly diverse under storey in the plantation forests and thus they could have been sampled with an additional plot. For trees this short inventory time did not enable as good sampling as for non-trees, but nevertheless the collected data can be used as a basis for recommendations and considerations of further inventories of the forests. For trees the accumulation curves show in most of the land types no levelling down, pointing to the need for more plots, which were unfeasible considering the time constraints. 

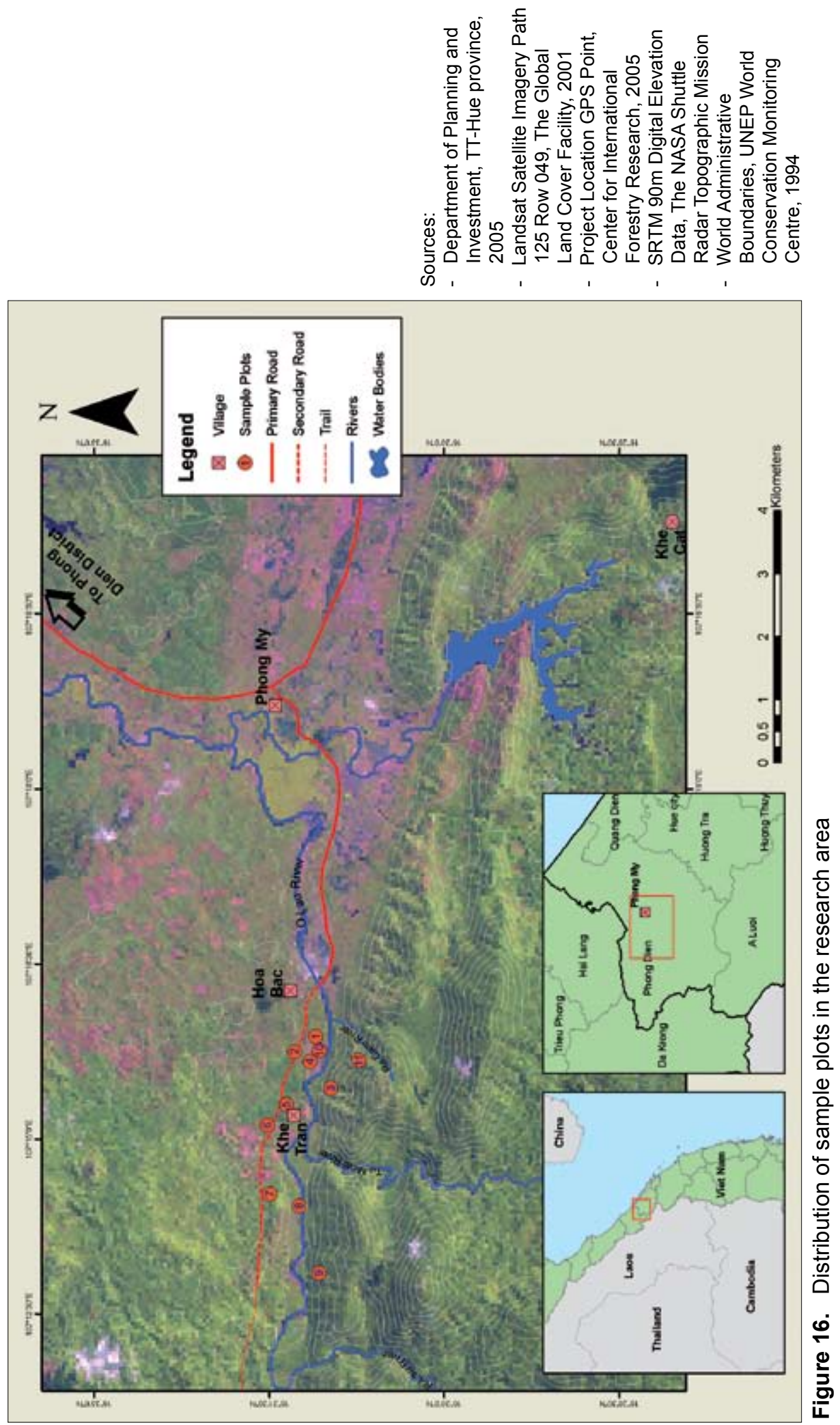
Table 19. Summary of specimen collection and identification of plant species from 11 sample sites

\begin{tabular}{|c|c|c|c|c|}
\hline & Family & Genus & Species & $\begin{array}{l}\text { Total } \\
\text { records }\end{array}$ \\
\hline Tree & $\begin{array}{l}39 \\
\text { Identified }=34 \\
\text { Unidentified }=5\end{array}$ & $\begin{array}{l}65 \\
\text { Identified }=56 \\
\text { Unidentified }=9\end{array}$ & $\begin{array}{l}98 \\
\text { Completely identified }=71 \\
\text { Identified up to genus }=18 \\
\text { Unidentified }=9\end{array}$ & 268 \\
\hline Non-tree & $\begin{array}{l}80 \\
\text { Identified }=64 \\
\text { Unidentified }=16\end{array}$ & $\begin{array}{l}172 \\
\text { Identified }=130 \\
\text { Unidentified }=42\end{array}$ & $\begin{array}{l}292 \\
\text { Completely identified }=166 \\
\text { Identified up to genus }=84 \\
\text { Unidentified }=42\end{array}$ & 413 \\
\hline Abundant* & $\begin{array}{l}28 \\
\text { Identified }=25 \\
\text { Unidentified }=3\end{array}$ & $\begin{array}{l}50 \\
\text { Identified }=40 \\
\text { Unidentified }=10\end{array}$ & $\begin{array}{l}62 \\
\text { Completely identified }=34 \\
\text { Identified up to genus }=18 \\
\text { Unidentified }=10\end{array}$ & 73 \\
\hline All plants & $\begin{array}{l}108 \\
\text { Identified }=84 \\
\text { Unidentified }=24\end{array}$ & $\begin{array}{l}260 \\
\text { Identified }=199 \\
\text { Unidentified }=61\end{array}$ & $\begin{array}{l}439 \\
\text { Completely identified }=261 \\
\text { Identified up to genus }=117 \\
\text { Unidentified }=61\end{array}$ & 754 \\
\hline
\end{tabular}

*Abundant refers to the seedling, sapling, shrub and monocot species separately recorded in the field as the most abundant ones based on expert opinion.

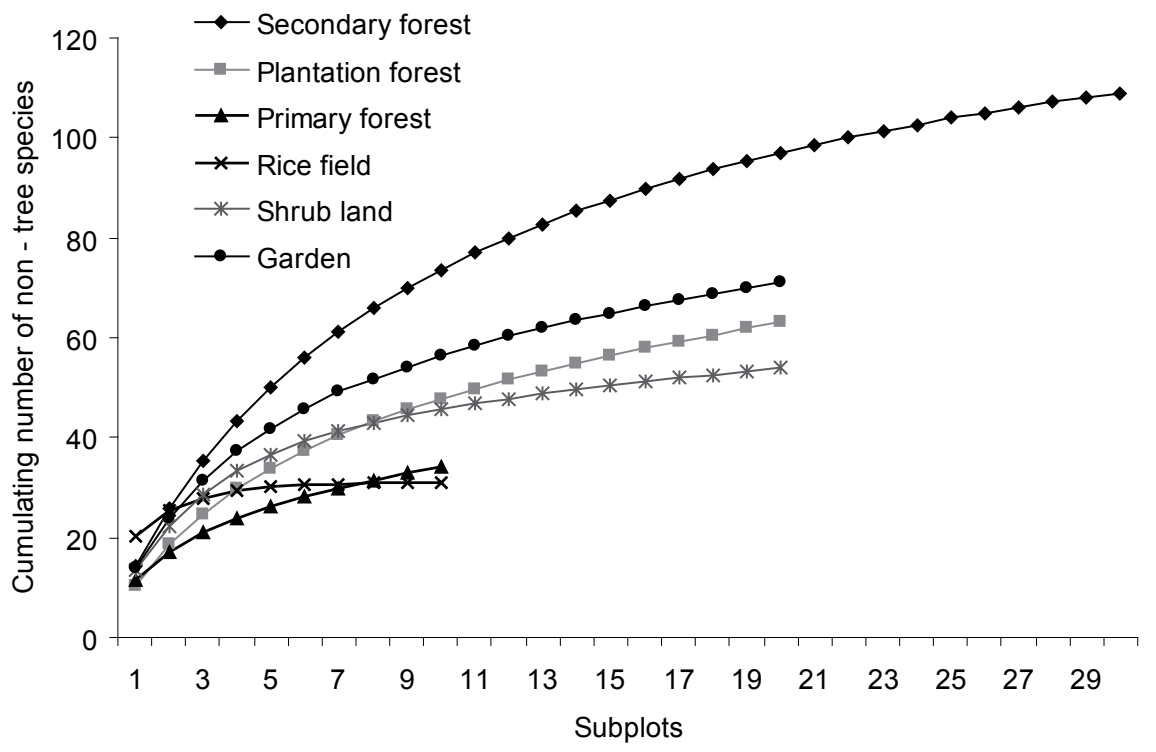

Figure 17. Accumulation of non-tree species with the increasing random order of subplots (each $20 \mathrm{~m}^{2}$ ) for land types in Khe Tran 


\subsection{Plant biodiversity}

Tree species $(\mathrm{dbh} \geq 10 \mathrm{~cm})$ among 39 families and non-tree species among 80 families were inventoried. The most common families among non-trees were Cyperaceae and Poaceae, both of which were present in 10 of the 11 plots. The most common families among trees and non-trees combined were Rubiaceae and Euphorbiaceae (each found in 9 plots) and Fabaceae (8). Among trees the most common families were Euphorbiaceae and Moraceae (5) followed by Lauraceae, Myrtaceae and Rubiaceae (4).

Twenty-eight percent of identified families and $84 \%$ of all plant species were singletons, present in only one plot, which indicates the high diversity of vegetation and large differences among land types. This view is also supported by the data from non-tree species alone, in which case 68 of the total of 292 species (identified and unidentified lumped together) were present in only one subplot (out of 110 subplots), 38 in two subplots and 258 species (88\%) were present in only one land type. Only a few true generalists were recorded in many land types. The most common and abundant non-trees were the herbs Centella asiatica (Apiaceae), present in 34 subplots and four land types, Catimbium breviligulatum (Zingiberaceae) in 33 subplots in four land types, and Curculigo cf. capitulata (Hypoxidaceae) in 10 subplots and four land types. The next most common ones were Hypolytrum nemorum (Cyperaceae) $(23,4)$, Schizostachyum cf. gracile (Poaceae) $(23,2)$, Paspalum conjugatum (Poaceae) $(21,3)$ and Cleome viscosa (Capparaceae) $(19,1)$. Nevertheless only a few species were shared between different land types.

Secondary forests stand mainly on steep slopes and consist of diverse tree species (from 20 to 30 tree species per plot, tree richness index from 0.81 to 0.91 ), often with fairly open canopy and dense understorey. Basal area in secondary forests varied from 11 to $17 \mathrm{~m}^{2} \mathrm{ha}^{-1}$. Relative dominance of a species is commonly expressed as percentage of the total basal area. Based on this index one more dominating tree species in secondary forests was identified (Figure 18). Barringtonia macrostachya (Lecythidaceae) was recorded in all secondary forest plots with its relative dominance always being close to $35 \%$. Its relative abundance (percentage of the total number of individuals per plot) varied from 15\% to $43 \%$. Other species with relative large basal areas were Cinnamomum cf. burmannii (Lauraceae) (21\% present in one plot) and Aporosa tetrapleura (Euphorbiaceae) (relative dominance from $2 \%$ to $8 \%$ in three plots, present in both secondary and primary forest). In secondary forests 55 tree species (132 individuals) out of the total of 70 species were present with a single individual, indicating high overall diversity of the forests and the need for larger sample size for trees if more rigorous information on them is needed.

Planted and managed forests are very common and promoted by the government, thus many bare hills have recently been converted into mixed fast wood plantations of Acacia mangium, Acacia auriculiformis and Acacia siamensis (Plot 5) or rubber (Hevea brasiliensis) plantations (Plot 1). Since for example $A$. mangium reaches harvest age in a mere 6 to 8 years after planting, the landscape has changed fast. Planting Acacia has also been supported by its catalyzing effect 


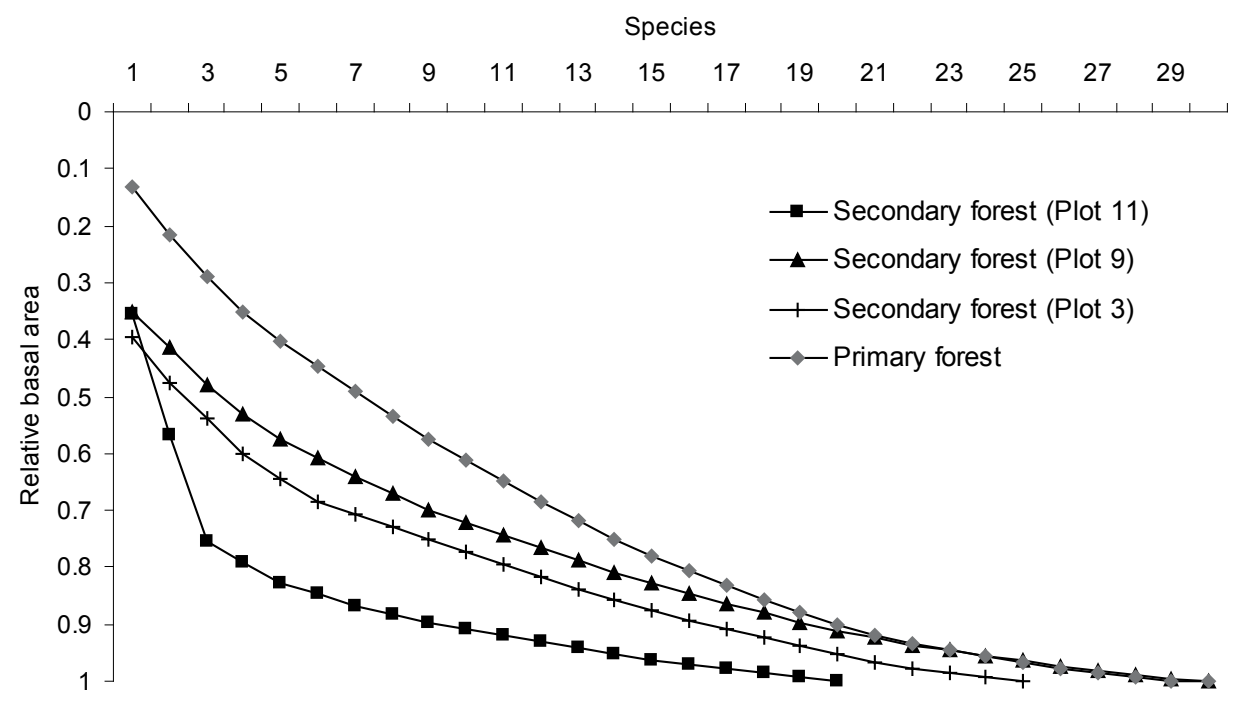

Figure 18. Relative dominance in primary and secondary forest plots in Khe Tran based on basal area

on the growth of natural forest tree species. Many of the fast wood plantations close to the village were not intensively managed and the plot located in Acacia plantation shows that the diversity of non-tree species in the understorey was relatively high (on average 32 species per plot), even comparable to secondary forests (from 27 to 51) (Table 20).

The primary forests (which could also be considered to be old secondary forests) of the area are relatively inaccessible because of the distance and their rarity due to the disturbance history. The most abundant species in the primary forest were Adinandra cf. hainanensis (Theaceae), Aporosa tetrapleura and $A$. dioica, all with $7 \%$ of the total number of individuals in the plot of primary forest.

The most abundant seedlings in the understorey of Acacia plantation were not Acacia but species from the genera Ficus (Moraceae) and Eurya (Theaceae) and saplings of Maesa balansae (Myrsinaceae). The only primary forest plot had relatively open canopy and thus an almost as diverse understorey as secondary forests or bare hills (shrub lands) with abundant seedlings from Myrtaceae and saplings from Lauraceae and Polygalaceae. In the understorey of rubber plantations the most abundant tree seedling was Mallotus paniculatus (Euphorbiaceae), sapling Maesa balansae with the most abundant shrub Melastoma sp.1 (Melastomataceae). None of the recorded most abundant seedlings or saplings were present as main tree species in respective land use type. Most of the main tree species have specified use value for local people, and Table 21 shows different land types with the main tree species and their importance to local livelihoods. The main uses for tree products are for construction, firewood and food, which can be considered major forest services. 
Table 20. Plant richness in Khe Tran

\begin{tabular}{lccccccc}
\hline Land type & Plot & $\begin{array}{c}\text { Tree } \\
\text { richness* }\end{array}$ & $\begin{array}{c}\text { Number } \\
\text { of tree } \\
\text { individuals } \\
\text { recorded }\end{array}$ & $\begin{array}{c}\text { Number } \\
\text { of tree } \\
\text { species }\end{array}$ & $\begin{array}{c}\text { Mean } \\
\text { number } \\
\text { of tree } \\
\text { species }\end{array}$ & $\begin{array}{c}\text { Number } \\
\text { of non- } \\
\text { tree } \\
\text { species }\end{array}$ & $\begin{array}{l}\text { Mean } \\
\text { number } \\
\text { of non- } \\
\text { tree } \\
\text { species }\end{array}$ \\
\hline Garden & 4 & 0.25 & 16 & 2 & 2 & 46 & 37 \\
\hline Plantation & 1 & 0.00 & 40 & 1 & 2 & 25 & 33 \\
forest & 5 & 0.30 & 40 & 3 & 27 & 39 & 33 \\
\hline Primary & 7 & 0.91 & 40 & 29 & $\mathbf{2 9}$ & 33 & 31 \\
forest & 10 & n.a. & 0 & 0 & 0 & 31 & 31 \\
\hline Rice field & 10 & 0.87 & 40 & 25 & & 36 & \\
\hline Secondary & 3 & $\mathbf{0 . 9 2}$ & 40 & $\mathbf{3 0}$ & 25 & $\mathbf{5 1}$ & $\mathbf{4 1}$ \\
forest & 11 & 0.81 & 40 & 20 & & 36 & \\
\hline Shrub & 2 & n.a. & 0 & 0 & 0 & 30 & 27 \\
land & 8 & n.a. & 0 & 0 & 0 & 24 & \\
\hline
\end{tabular}

*Tree richness $=\log _{10}$ sp/ $/ \log _{10}$ count

n.a. means not applicable

\subsection{Forest structure}

Richness of life forms of non-tree species varied substantially among land types. Epiphytes were present in only one secondary forest plot. Herbs, with 190 species, were the richest non-tree life form category in all land types, especially in more open and managed areas such as dry rice fields and gardens. Lianas, climbers and ferns were also present in all of the land types, except rice fields (Table 22).

Secondary forests had the highest canopy, highest dbh and second lowest furcation index, as illustrated in Figure 19 on the right. Mean height of the secondary forest varied from 10 to $17 \mathrm{~m}$ with a maximum of two canopy layers, which indicates the lack of high primary forest species. Mean height of the primary forest was $14 \mathrm{~m}$, which is in line with other survey results from this area (e.g. Le Trong Trai et al. 2001). Canopy height in plantation forest varied between 14 and $16 \mathrm{~m}$ and in gardens from 6 to $10 \mathrm{~m}$.

Furcation index indicates the plant height where apical dominance is no longer a property of a single defined stem. It was recorded on a continuous scale from 0 to $110 \%$ (the latter being a tree trunk without clear dominant stem). Some structural features of trees may be linked to their disturbance history and MLA experiences from, for example, Papua and Kalimantan show that apical dominance is generally low in primary rainforests with closed canopy. An increase of value may reflect the rate of disturbance in the forests (trees resprout after breakage) and history of utilization of trees. As presented in Figure 19, on the right, furcation index values in Khe Tran varied from 30 to 63 . The highest value was recorded in rubber plantation and the lowest ones in the most distant secondary forest plots and Acacia plantation without intensive management. 
Table 21. Main tree species based on basal area and density listed with their uses in Khe Tran

\begin{tabular}{|c|c|c|c|c|}
\hline $\begin{array}{l}\text { Land } \\
\text { type }\end{array}$ & Main tree species & Uses & $\begin{array}{c}\text { Basal area } \\
\left(\mathrm{m}^{2} \mathrm{ha}^{-1}\right)\end{array}$ & $\begin{array}{c}\text { Density } \\
\text { (tree ha-1) }\end{array}$ \\
\hline \multirow{3}{*}{ 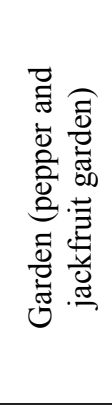 } & $\begin{array}{l}\text { Artocarpus } \\
\text { heterophyllus }\end{array}$ & $\begin{array}{l}\text { Food (fruit), heavy and light } \\
\text { construction (timber for house } \\
\text { and cattle barn), firewood }\end{array}$ & 2.3 & 100 \\
\hline & cf. Moraceae & $\begin{array}{l}\text { Food (fruit), heavy } \\
\text { construction (timber for } \\
\text { house), support stalk for } \\
\text { growing of pepper }\end{array}$ & 0.6 & 73 \\
\hline & Unknown species & $\begin{array}{l}\text { Tree used as a support stalk for } \\
\text { growing of pepper }\end{array}$ & 2.5 & 233 \\
\hline \multirow{3}{*}{ 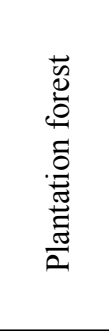 } & Acacia auriculiformis & $\begin{array}{l}\text { Heavy construction (timber } \\
\text { for house), marketable item } \\
\text { (timber for pulp), firewood }\end{array}$ & 5.8 & 429 \\
\hline & Acacia mangium & $\begin{array}{l}\text { Heavy construction (timber } \\
\text { for house), marketable item } \\
\text { (timber for pulp), firewood }\end{array}$ & 1.3 & 67 \\
\hline & Hevea brasiliensis & Marketable item (latex) & 11.0 & 398 \\
\hline \multirow{5}{*}{ 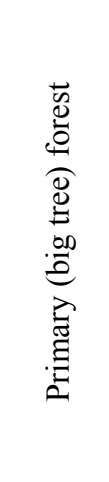 } & $\begin{array}{l}\text { Adinandra cf. } \\
\text { hainanensis }\end{array}$ & Firewood & 1.0 & 53 \\
\hline & Aporosa tetrapleura & $\begin{array}{l}\text { Heavy construction (timber } \\
\text { for house), firewood, light } \\
\text { construction (timber for cattle } \\
\text { barn) }\end{array}$ & 0.8 & 51 \\
\hline & cf. Osmanthus sp.1 & Firewood & 1.8 & 40 \\
\hline & $\begin{array}{l}\text { Syzygium cf. } \\
\text { cochinchinensis }\end{array}$ & $\begin{array}{l}\text { Heavy construction (timber for } \\
\text { house) }\end{array}$ & 1.2 & 28 \\
\hline & Vitex trifolia & Firewood & 0.5 & 45 \\
\hline \multirow{4}{*}{ 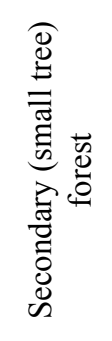 } & Aporosa tetrapleura & $\begin{array}{l}\text { Firewood, light construction } \\
\text { (timber for cattle barn) }\end{array}$ & 7.1 & 42 \\
\hline & $\begin{array}{l}\text { Barringtonia } \\
\text { macrostachya }\end{array}$ & Food, firewood & 5.3 & 123 \\
\hline & $\begin{array}{l}\text { Cinnamomum cf. } \\
\text { burmannii }\end{array}$ & Firewood & 3.7 & 19 \\
\hline & Fagaceae & Firewood & 3.2 & 43 \\
\hline
\end{tabular}

Trees with $\mathrm{dbh} \geq 10 \mathrm{~cm}$ are clearly smaller and growing less densely in gardens compared to other land types with trees. Density is very similar in plantations and secondary forests, but the latter has clearly higher basal areas per hectare. 
Table 22. Richness (total number of species recorded per plot) of life forms of non-tree species in all land types in Khe Tran

\begin{tabular}{|c|c|c|c|c|c|c|c|c|c|}
\hline Land type & 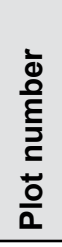 & $\begin{array}{l}\text { ڤ0 } \\
\text { 잉 } \\
\text { I }\end{array}$ & 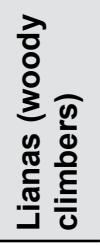 & 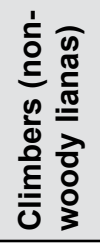 & $\frac{\mathscr{E}}{\pi}$ & 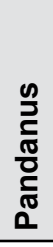 & 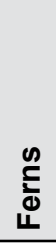 & 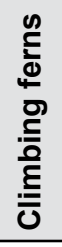 & 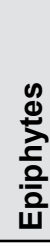 \\
\hline \multirow{2}{*}{ Garden } & 4 & 38 & 4 & 2 & & & 2 & & \\
\hline & 6 & 10 & 8 & 5 & 1 & & 3 & & \\
\hline \multirow{2}{*}{ Plantation forest } & 1 & 21 & 1 & & & & 3 & & \\
\hline & 5 & 14 & 13 & 6 & & & 6 & & \\
\hline Primary forest & 7 & 12 & 10 & 5 & 1 & 3 & 2 & & \\
\hline Rice field & 10 & 31 & & & & & & & \\
\hline \multirow{3}{*}{ Secondary forest } & 3 & 15 & 12 & 2 & 3 & & 4 & & \\
\hline & 9 & 7 & 14 & 3 & 7 & 2 & 2 & & \\
\hline & 11 & 13 & 17 & 3 & 8 & 2 & 5 & 2 & 1 \\
\hline \multirow{2}{*}{ Shrub land } & 2 & 16 & 2 & 3 & & & 7 & 2 & \\
\hline & 8 & 20 & & & & & 2 & 2 & \\
\hline All plots & & 190 & 77 & 27 & 20 & 5 & 36 & 6 & 1 \\
\hline
\end{tabular}

\subsection{Species vulnerability}

Ten plant species with threatened status were recorded in the field and/or in PDM exercises. These threatened species and their status are shown in Table 23. Species with undefined status are omitted. Data is based on checklist of WCMC (1994) and IUCN (2006). None of the red-listed plant species recorded at Phong Dien and Dakrong Nature Reserves and reported by BirdLife (Le Trong Trai et al. 2001) were found in the sample plots.

For most of these threatened species villagers named uses, and four of the species, Hopea odorata, Parashorea stellata, Afzelia xylocarpa and Pinus latteri, were valued as very important ones. Those were found only outside the sampling plots. Most of the threatened species recorded in the field were found in secondary forests and no threatened species were found from intermediate or cultivated land types.

All of the threatened species were considered to have substitute sources for their particular use. Calamus tonkinensis, which is used for making furniture and building roofs, is also listed as threatened. The biggest threats to Parashorea stellata are habitat degradation and wood clear cutting, the latter being also conducted by Khe Tran villagers. According to IUCN (2006), Amesiodendron chinense is a dominant component of some forest localities and has been observed to regenerate well, although population reductions have occurred. It was considered 

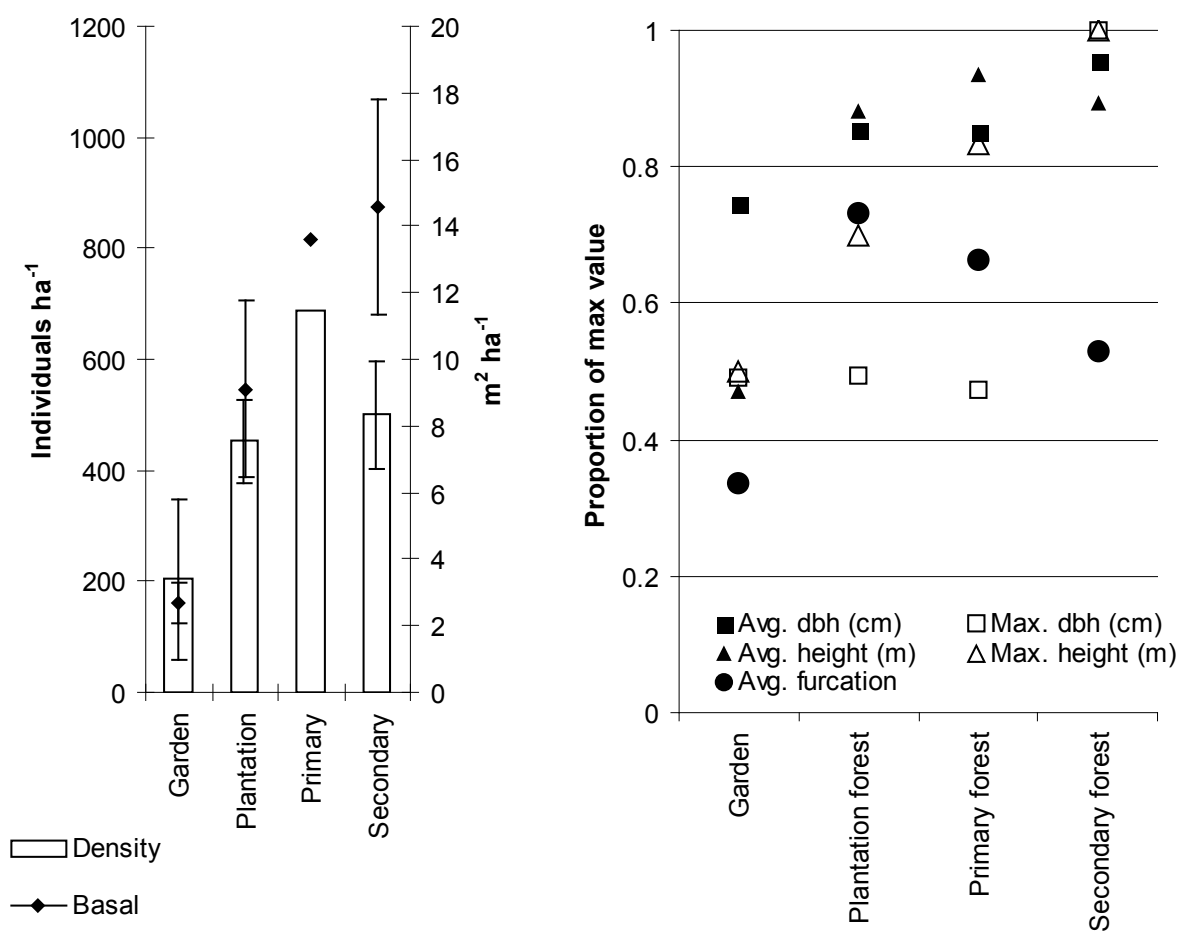

Figure 19. Forest structural characteristics in Khe Tran. Left panel: basal area and density; right panel: tree height, stem diameter and furcation index

a marketable item in the village. Apart from threatened status, Gnetum montanum (present in secondary forest, in one plot), which is one of the CITES-listed species for Vietnam, listed in Annex 3, was not valued as useful species since it was mentioned many times without uses and only once as a source of children food. 
Table 23. Threatened species in Khe Tran based on vegetation inventories and PDM exercises

\begin{tabular}{|c|c|c|c|c|}
\hline Species & Family & Uses & Status $^{1}$ & Land use type \\
\hline Calamus dioicus & Arecaceae & Basketry & $\mathrm{R}$ & Secondary forest \\
\hline Calamus salicifolius & Arecaceae & None & $\mathrm{R}$ & Secondary forest \\
\hline Calamus tonkinensis & Arecaceae & $\begin{array}{l}\text { Heavy and light } \\
\text { construction }\end{array}$ & $\mathrm{R}$ & Secondary forest \\
\hline Epiprinus balansae & Euphorbiaceae & Firewood & $\mathrm{R}$ & Secondary forest \\
\hline Hopea odorata & Dipterocarpaceae & Marketable item & $\mathrm{VU}^{*}$ & 2 \\
\hline Parashorea stellata & Dipterocarpaceae & $\begin{array}{l}\text { Heavy } \\
\text { construction }\end{array}$ & $\mathrm{CR}^{*}$ & 2 \\
\hline Afzelia xylocarpa & Mimosaceae & Marketable item & $\mathrm{EN}^{*}$ & 2 \\
\hline Pinus latteri & Pinaceae & Marketable item & $\begin{array}{l}\mathrm{R}, \mathrm{LR} / \\
\mathrm{NT}^{*}\end{array}$ & 2 \\
\hline $\begin{array}{l}\text { Amesiodendron } \\
\text { chinense }\end{array}$ & Sapindaceae & $\begin{array}{l}\text { Heavy } \\
\text { construction, } \\
\text { firewood }\end{array}$ & LR/NT* & $\begin{array}{l}\text { Primary forest, } \\
\text { secondary forest }\end{array}$ \\
\hline Camellia cf. fleuryi & Theaceae & $\begin{array}{l}\text { Firewood, heavy } \\
\text { construction }\end{array}$ & $\mathrm{R}, \mathrm{VU}^{*}$ & Primary forest \\
\hline
\end{tabular}

${ }^{1}$ Status according to WCMC (1994) without asterisk, according to IUCN (2006) with asterisk. R: rare; VU: vulnerable; CR: critically endangered; EN: endangered; LR/ NT: near threatened.

${ }^{2}$ Recorded in PDM exercise as locally important species, but not observed in the field plots. 


\section{Summary}

The flora of Khe Tran exhibits high species richness, and although our sampling was not exhaustive, it is sufficiently rigorous to address the value and relative richness of remaining natural forests as well as other land types. It also shows that the potentially monotonous land types, such as plantations or rice fields, are still very high in non-tree diversity in Khe Tran, which enables and maintains their multiuse function.

According to this survey, the people of Khe Tran represent no imminent threat for recorded endangered species. We recommend that information on threatened species be given to villagers to raise the awareness of conservation needs and that the specific uses of especially threatened species be discussed in order to give people the option to choose other species for these uses. It seems likely that the range of threats from cutting of construction material and collection of firewood and material for basketry may have contributed to the status of plant species in the past, but the impact at present is difficult to assess. Direct impact on forest cover or composition as a whole is impossible to quantify based on our sampling. Therefore further research on sustainability of NTFP collection is required. Most of the natural vegetation is disturbed forest or shrub lands and the impacts of floods and fires continue to influence forest cover and structure. The most substantive influence on remaining forests may be the way of planning and measure of recognising the outside effect on land types. During the fieldwork we saw many people coming from elsewhere to collect NTFPs and some marks of illegal logging conducted by people from outside the area. 


\section{Ethno-botanical knowledge}

\subsection{Plant uses}

We categorized all the uses of plants recorded in the field according to the categories used in the PDM exercise (Table 7, Chapter 6). In addition a category of 'miscellaneous' was created for 15 species that were outside the most common use categories. In the miscellaneous group we find: fertilizer, support stalk for growth of pepper, fabric dye, shampoo, charcoal to blacken teeth, incense and furniture polish. Similarly to the results from the PDM exercises, no plant was recorded for the future and hunting place categories.

The result of herbarium identification shows that $71 \%$ species gathered are useful species from 81 families and 164 genus (Table 24). Annex 3 provides local uses information of collected plants with their botanical names, families and local names.

Table 24. Summary of specimen collection and identification of plant species from 11 sample sites

\begin{tabular}{llll}
\hline & Family & Genus & Species \\
\hline $\begin{array}{l}\text { Total } \\
\text { collected } \\
\text { plants }\end{array}$ & $\begin{array}{l}\text { Identified }=84 \\
\text { Unidentified }=24\end{array}$ & $\begin{array}{l}260 \\
\text { Identified }=199 \\
\text { Unidentified }=61\end{array}$ & $\begin{array}{l}439 \\
\text { Completely identified }=261 \\
\text { Identified up to sp. }=117 \\
\text { Unidentified }=61\end{array}$ \\
$\begin{array}{l}\text { Total useful } \\
\text { plants }\end{array}$ & 81 & 202 & 312 \\
& $\begin{array}{l}\text { Identified }=72 \\
\text { Unidentified }=9\end{array}$ & $\begin{array}{l}\text { Identified }=164 \\
\text { Unidentified }=38\end{array}$ & $\begin{array}{l}\text { Completely identified }=202 \\
\text { Identified up to sp. }=72 \\
\text { Unidentified }=38\end{array}$ \\
\hline
\end{tabular}

Trees are very useful for the Khe Tran people (Table 25). From the total of 98 tree species recorded in the 11 plots, 94 have at least one use. All trees recorded 
$(\mathrm{dbh} \geq 10 \mathrm{~cm})$ in the garden and plantation forest are considered useful, which reflects the fact that these forests are relatively intensively managed and mainly useful species are left to grow there. No tree was found in the rice fields and shrub lands, as they are usually cut at the seedling stage.

Table 25. Mean number of species and number of useful species recorded in each land type

\begin{tabular}{lcccclc}
\hline & $\begin{array}{l}\text { Mean } \\
\text { number } \\
\text { of } \\
\text { species }\end{array}$ & $\begin{array}{l}\text { Mean } \\
\text { number } \\
\text { of useful } \\
\text { species }\end{array}$ & $\begin{array}{l}\text { Percent } \\
\text { useful }\end{array}$ & $\begin{array}{l}\text { Mean } \\
\text { number } \\
\text { of } \\
\text { species }\end{array}$ & $\begin{array}{l}\text { Mean } \\
\text { number } \\
\text { of useful } \\
\text { species }\end{array}$ & $\begin{array}{l}\text { Percent } \\
\text { useful }\end{array}$ \\
\hline Land type & $98^{*}$ & $94 *$ & 96 & $292^{*}$ & $175^{*}$ & 60 \\
\hline All plots $(\mathrm{n}=11)$ & 2 & 2 & $\mathbf{1 0 0}$ & 37 & $\mathbf{2 7}$ & 73 \\
Garden $(\mathrm{n}=2)$ & 2 & 2 & $\mathbf{1 0 0}$ & 33 & 21 & 62 \\
Plantation forest $(\mathrm{n}=2)$ & $\mathbf{2 9}$ & $\mathbf{2 7}$ & 93 & 33 & 11 & 33 \\
Primary forest $(\mathrm{n}=1)$ & 0 & 0 & 0 & 31 & 24 & $\mathbf{7 7}$ \\
Rice field $(\mathrm{n}=1)$ & 25 & 22 & 87 & $\mathbf{4 1}$ & 15 & 37 \\
Secondary forest $(\mathrm{n}=3)$ & 0 & 0 & 0 & 27 & 17 & 61 \\
\hline Shrub land $(\mathrm{n}=2)$ & & & & & &
\end{tabular}

${ }^{*}$ Total number of species from all plots

At the time of the fieldwork the rice field was dry, a young fallow during a short period before the rainy season returned with the new planting. It had the highest percentage of useful non-tree species (77\%, 24 species) of all land types, while primary forest had the lowest (33\%, 11 species).

For all non-trees, the percentage of useful species is higher in cultivated areas (rice field, garden and plantation forest) than in other places, including the natural forest. This reflects the distance and accessibility of the different areas for the local people. Since villagers visit the cultivated areas more often than they go to the natural forest, they are more familiar with the plants near the settlement. In comparison with the PDM exercise for the source of products, cultivated plants have more value than wild plants (Figure 12, Chapter 6).

The use categories with the largest total number of recorded useful species are firewood, fodder and food. Firewood is gathered mainly from the natural forest, while fodder is found mainly in gardens and rice fields (after harvest). Food comes mainly from the garden. Therefore even if forests are important in most of the categories of uses, land types near the village, such as gardens, plantations and rice fields, are the most important for the main categories (Table 26). 
Table 26. Distribution of all useful plant species per plot and by use category

\begin{tabular}{|c|c|c|c|c|c|c|c|c|c|c|c|c|c|c|c|c|}
\hline Land type & 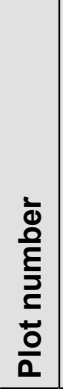 & 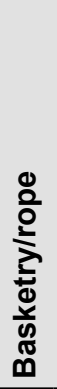 & 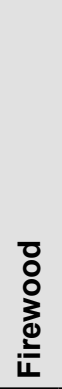 & $\begin{array}{l}\frac{1}{ \pm} \\
\frac{0}{0} \\
\text { 노 }\end{array}$ & $\begin{array}{l}\text { 웅 } \\
\text { 우 }\end{array}$ & 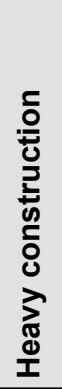 & 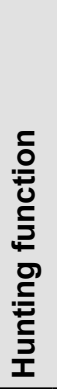 & 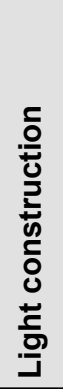 & 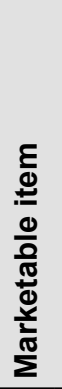 & $\begin{array}{l}\frac{0}{0} \\
\frac{0}{0} \\
\frac{0}{\Sigma} \\
\Sigma\end{array}$ & 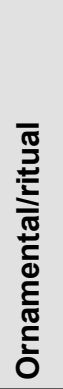 & 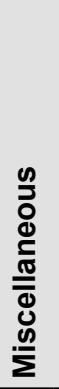 & 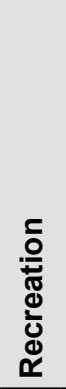 & $\begin{array}{l}\frac{\infty}{8} \\
\stackrel{0}{\circ}\end{array}$ & 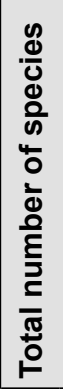 & 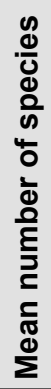 \\
\hline \multirow{2}{*}{ Garden } & 4 & & 1 & 24 & 8 & 2 & & & 1 & 5 & & 5 & & & 38 & \multirow{2}{*}{32} \\
\hline & 6 & 1 & 6 & 9 & 11 & 1 & 2 & 2 & 3 & 5 & & 2 & & 1 & 25 & \\
\hline \multirow{2}{*}{ Plantation forest } & 1 & & 4 & 12 & 5 & 1 & & 1 & 3 & 6 & 1 & 1 & & & 25 & \multirow{2}{*}{30} \\
\hline & 5 & 1 & 13 & 12 & 8 & 3 & & 2 & 4 & 4 & 1 & & 1 & 1 & 35 & \\
\hline Primary forest & 7 & 3 & 23 & 1 & 5 & 15 & 1 & 4 & 1 & 4 & 2 & 1 & & 2 & 39 & 39 \\
\hline Rice field & 10 & & & 19 & 5 & & & & 2 & 2 & & 1 & & & 24 & 24 \\
\hline \multirow{3}{*}{ Secondary forest } & 3 & & 19 & 5 & 8 & 11 & 3 & 11 & 2 & 2 & 4 & 4 & & 3 & 50 & \multirow{3}{*}{46} \\
\hline & 9 & 4 & 29 & 2 & 5 & 11 & 1 & 2 & & 1 & 4 & 3 & & 2 & 49 & \\
\hline & 11 & 3 & 24 & & 8 & 3 & 1 & 1 & 1 & 3 & 1 & & & 2 & 39 & \\
\hline \multirow{2}{*}{ Shrub land } & 2 & & 7 & 11 & 5 & 1 & & & 1 & 2 & 1 & & & 1 & 22 & \\
\hline & 8 & & 5 & 11 & 3 & 1 & & 1 & 1 & 2 & 1 & 1 & 1 & & 22 & \\
\hline All plots & & 12 & 117 & 89 & 57 & 44 & 5 & 21 & 16 & 29 & 15 & 18 & 2 & 11 & 318 & \\
\hline
\end{tabular}

\subsection{Species with multiple uses}

Some species have multiple uses (Table 27), as is apparent in the following examples. The most multipurpose species is Gigantochloa sp. (giant bamboo), which is used for basketry, firewood, food (from the shoot), fodder (leaf), fence for cattle facility, marketable item (chopstick) and tools. Giant bamboo was only present near the jackfruit garden, but grows abundantly in the whole area, not far from the settlements. Imperata cylindrica (Cogon grass) is used for spice (from the roots), medicine (root), thatching (leaf) and fodder (leaf). Macaranga trichocarpa, a pioneer species, indicates disturbance in forests and is commonly used by local people. It was not very abundant (one individual in each secondary forest plot), although rather common in secondary forest. Drink made from its leaves is believed to improve and maintain health and its wood is used for firewood. In the past this species was also used to make beds. Artocarpus heterophyllus (jackfruit) is used for firewood, heavy and light construction and food (fruits). 
Table 27. Plant species with at least four uses

\begin{tabular}{|c|c|c|c|c|c|c|c|c|c|c|c|}
\hline Botanical name & Family & Local name & 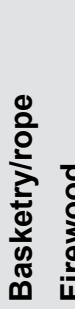 & 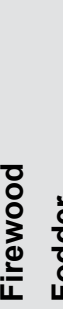 & $\frac{1}{\grave{o}}$ & 8 & 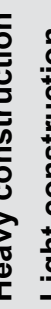 & 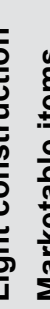 & 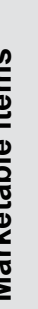 & & $\frac{\infty}{\circ}$ \\
\hline Gigantochloa sp. & Poaceae & Abung & & & & & & & & & \\
\hline Artocarpus heterophyllus & Moraceae & Pa nây & & & & & & & & & \\
\hline Calamus sp.1 & Arecaceae & Ki re & & & & & & & & & \\
\hline Imperata cylindrica & Poaceae & A séc/Cá tranh & & & & & & & & & \\
\hline Schizostachyum cf. gracile & Poaceae & A tang/Ilatuvia & & & & & & & & & \\
\hline Unknown sp. 4 & Myrtaceae & Clem & & & & & & & & & \\
\hline Unknown sp. 22 & Unknown & A cê lem & & & & & & & & & \\
\hline
\end{tabular}

\subsection{Uses of trees}

For the local people trees in primary and secondary forest are useful for firewood, food, heavy and light construction, medicine, tools and miscellaneous uses (such as dye, shampoo, woody plant species taken from its original habitat and transplanted in the gardens to grow pepper on it; see Table 28). Trees in plantation forest are used mainly to obtain cash income from the latex from Hevea brasiliensis, the timber from Acacia auriculiformis, A. mangium and the pulp from A. siamensis. Villagers also use them for house construction and firewood.

From the garden, trees such as Artocarpus heterophyllus and unknown sp. 30 and 31, are used as resource for firewood, food (fruit), timber for heavy and light construction, and as support stalk for pepper. Barringtonia macrostachya, which is the main tree in secondary forests, is used for firewood and its fruits were important sources of food during the war.

\subsection{Uses of non-trees}

Based on the PDM exercise result, domesticated animals are more important resources than wild and purchased ones. Fortunately Khe Tran has plenty of different species of plants ( 89 species) that can be used as fodder (Figure 20). They only use non-tree species for that purpose. Even if primary and secondary forests provide virtually many plant species that could be used as fodder, villagers do not need to go that far to get this kind of product because many varieties are available in the rice fields, gardens, plantations and shrub land, which are more accessible. Rice field has the highest number of plants used for fodder (19 species, see Table 29), but only after harvest. 
Table 28. Distribution of tree species considered useful per plot and per use category

\begin{tabular}{|c|c|c|c|c|c|c|c|c|c|c|}
\hline Land type & 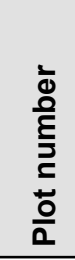 & 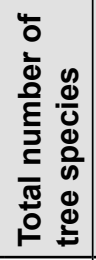 & 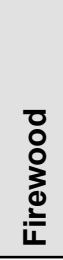 & $\begin{array}{l}\text { 웅 } \\
\text { ㄴ } \\
\end{array}$ & 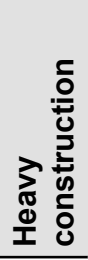 & 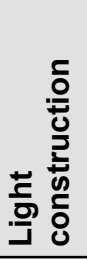 & 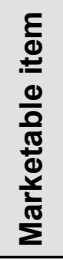 & $\begin{array}{l}\stackrel{0}{0} \\
\frac{0}{0} \\
\stackrel{0}{0}\end{array}$ & 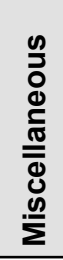 & $\begin{array}{l}\infty \\
\stackrel{0}{\circ} \\
\end{array}$ \\
\hline \multirow{2}{*}{ Garden } & 4 & 2 & & 1 & 1 & & & & 2 & \\
\hline & 6 & 1 & 1 & 1 & 1 & 1 & & & & \\
\hline \multirow{2}{*}{ Plantation forest } & 1 & 1 & & & & & 1 & & & \\
\hline & 5 & 3 & 3 & & 3 & & 3 & & & \\
\hline Primary forest & 7 & 29 & 23 & 1 & 13 & 3 & & 1 & 1 & 1 \\
\hline Rice field & 10 & 0 & & & & & & & & \\
\hline \multirow{3}{*}{ Secondary forest } & 3 & 25 & 17 & 2 & 8 & 5 & & & 2 & 2 \\
\hline & 9 & 30 & 23 & 1 & 9 & 2 & & & & \\
\hline & 11 & 20 & 18 & 1 & 2 & & & & & \\
\hline \multirow{2}{*}{ Shrub land } & 2 & 0 & & & & & & & & \\
\hline & 8 & 0 & & & & & & & & \\
\hline
\end{tabular}

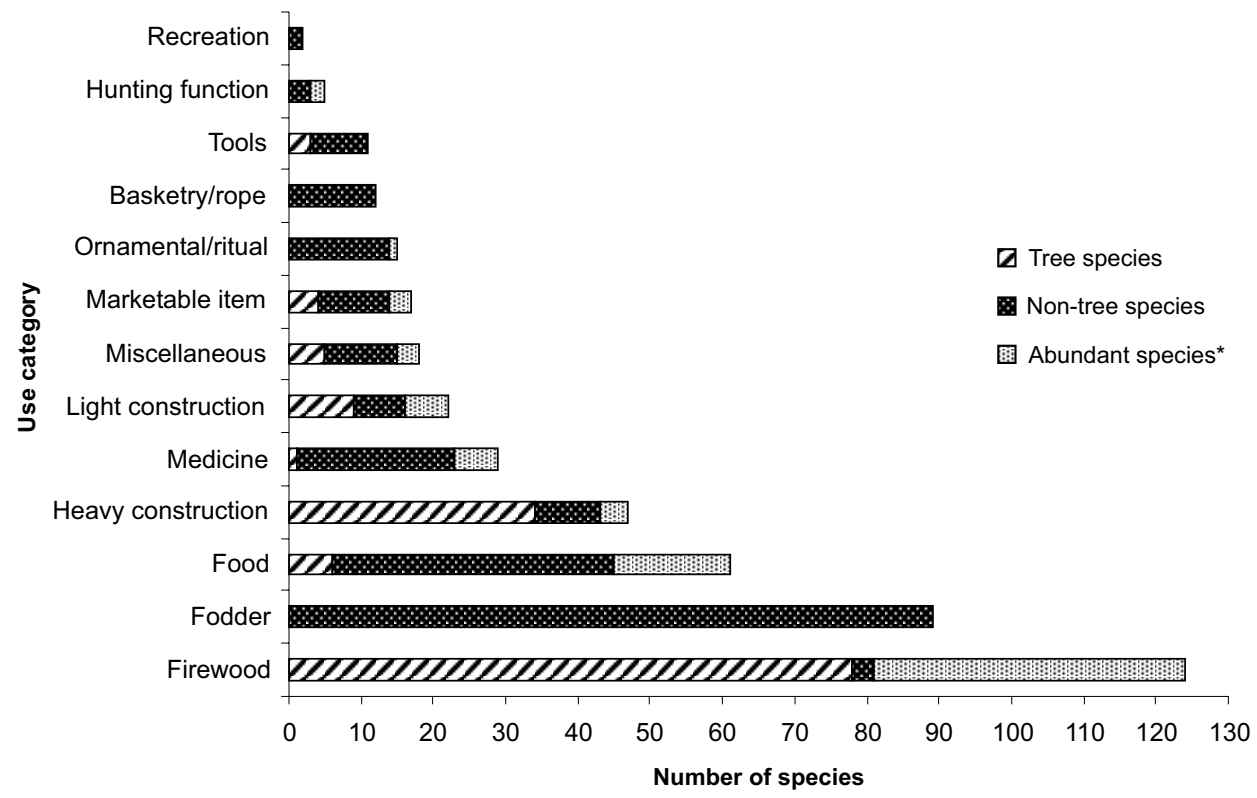

Figure 20. All plant species considered useful by the Khe Tran villagers shown in use categories

*Including the seedling, sapling, monocot or shrub of the tree and non-tree species 
For food and medicine they use, respectively, 39 and 22 non-tree species (Figure 20). Centella asiatica (Rau ma/Pahy), a major wild vegetable, is used for food and medicine, as well as sold in the market.

Table 29. Distribution of non-tree species considered useful per plot and per use category

\begin{tabular}{|c|c|c|c|c|c|c|c|c|c|c|c|c|c|c|c|}
\hline -and type & 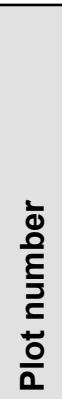 & 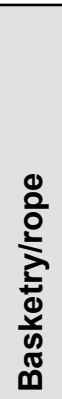 & 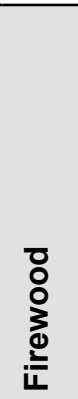 & $\begin{array}{l}\text { बे } \\
\text { 응 } \\
\text { ᄂ }\end{array}$ & $\begin{array}{l}\text { ¿ } \\
\text { ¿ }\end{array}$ & 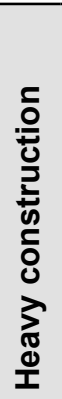 & 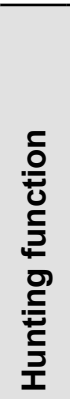 & 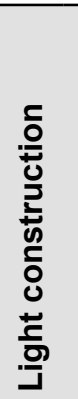 & 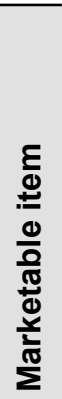 & 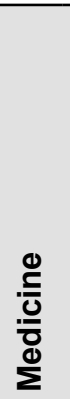 & 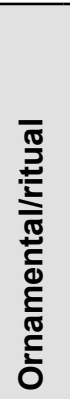 & 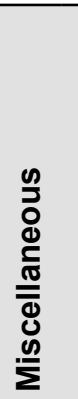 & 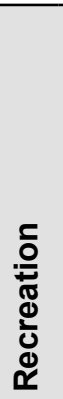 & $\begin{array}{l}\frac{\infty}{\circ} \\
\stackrel{0}{\circ}\end{array}$ & 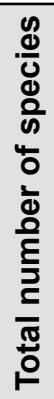 \\
\hline \multirow{2}{*}{ Garden } & 4 & & & 24 & 7 & 1 & & & 1 & 5 & & 3 & & & 46 \\
\hline & 6 & 1 & 1 & 8 & 7 & & 1 & 1 & 3 & 5 & & 2 & & 1 & 27 \\
\hline \multirow{2}{*}{$\begin{array}{l}\text { Plantation } \\
\text { forest }\end{array}$} & 1 & & & 12 & 4 & 1 & & 1 & 1 & 5 & 1 & & & & 25 \\
\hline & 5 & 1 & & 12 & 5 & & & & 1 & 3 & 1 & & 1 & 1 & 39 \\
\hline Primary forest & 7 & 3 & & 1 & 3 & 2 & 1 & 1 & 1 & 3 & 2 & & & 1 & 33 \\
\hline Rice field & 10 & & & 19 & 5 & & & & 2 & 2 & & 1 & & & 31 \\
\hline \multirow{3}{*}{$\begin{array}{l}\text { Secondary } \\
\text { forest }\end{array}$} & 3 & & & 5 & 4 & 3 & 1 & 3 & 2 & 1 & 3 & & & 1 & 36 \\
\hline & 9 & 4 & 1 & 2 & 3 & 2 & 1 & & & & 4 & 3 & & 2 & 51 \\
\hline & 11 & 3 & & & 7 & 1 & 1 & 1 & 1 & 2 & 1 & & & 2 & 36 \\
\hline \multirow{2}{*}{ Shrub land } & 2 & & 1 & 11 & 4 & & & & & & 1 & & & 1 & 30 \\
\hline & 8 & & & 11 & 2 & & & & & 2 & 1 & 1 & 1 & & 24 \\
\hline
\end{tabular}

\subsection{Forest as resource of useful plants}

The most important useful species recorded from the forest are used for firewood (101 species), followed by species for heavy construction (41 species) and food (35 species), as shown in Figure 21. The local people use not only wood species for firewood but also bamboo (Gigantocloa sp. 1, Schizostachyum cf. gracile and Stixis scandens).

Secondary forest has more species (18) used for the food category than plantation and primary forests (13 and 5 species, respectively), all plant forms considered. The species from primary forest are Artocarpus styracifolius (Moraceae), Linociera cf. ramiflora (Oleaceae), Zingiber sp. 2 (Zingiberaceae), Schizostachyum cf. gracile (Poaceae) and Tetracera sarmentosa ssp. asiatica (Dilleniaceae).

There are several plants from the forest, especially from plantation and secondary forests, appreciated by children for food: Catimbium breviligulatum (young stem), Dracaena sp. (shoot), Gnetum cf. montanum (fruit), Fibraurea recisa (fruit), Linociera cf. ramiflora (flower), Melastoma sp. 2 (fruit), Physalis angulata (fruit), Psychotria sp. 2 (fruit), Randia spinosa (fruit), Rubus sp. 2 (fruit) and Stixis suaveolens (fruit). 


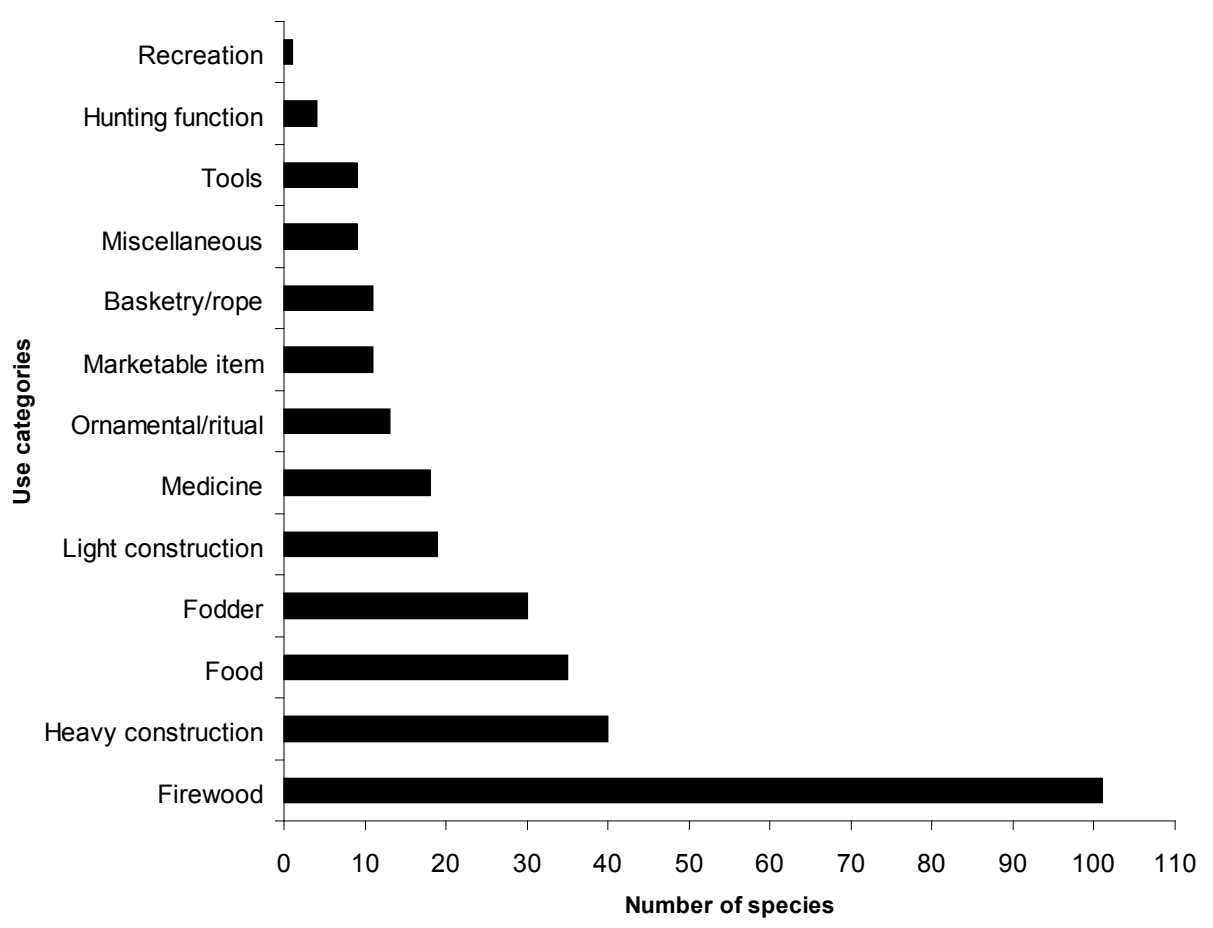

Figure 21. Total number of all useful plant species per category in primary, secondary and plantation forests

\subsection{Nonsubstitutable species}

Hevea brasiliensis, Imperata cylindrica, Centella asiatica and Gomphia serrata are the only plants that have functions or uses for which there were no known substitutes according to the villagers. Rubber is used for its latex, the following two as medicine and the last one to blacken the teeth (with its stem, which is turned into charcoal).

From the uses of plants and land types, we can admit that the livelihoods of villagers are no longer totally dependent on forests. We can observe a diversity of sources of income and materials, some of them still found in the natural forest. The multiple uses of land types show that people know their area still very well (see participatory map of resources, Figure 8 in page 27). During our survey some people said they were considering different options for use types concerning, for example, medicinal plants, but they expected more education and training to that end. They also considered the possibility of finding and using more ornamental plants. 'Life is easier nowadays, and one can start to think more about the additional recreational or aesthetic things like ornamental plants', said one villager. 


\subsection{Remarks on potential uses of species}

Saccharum spontaneum (Poaceae), which in Khe Tran is used for fodder, is a valuable medicinal plant in India (Oudhia 2004). There may be some potential in scoping further possibilities for this usage.

Caryota urens (Arecaceae) is recorded as food only in the past and the stems of Caryota monostachya are used to build floors, while Le Van Lan, Ziegler and Grever (2002) mentions that leaves of the Caryota sp. are used for building roofs and sheds, and their stalks for fences. He also lists that Ageratum conyzoides (Asteraceae) is medicinal plant against cold (Le Van Lan, Ziegler and Grever 2002).

More ethno-botanical and socio-economic studies are necessary to collect data on potentially economically viable plants that could be developed in the area, considering market demand and network, and the sustainability of resources.

\section{Summary}

The villagers use a large range of species for their livelihoods, not only from the natural forests, but on the contrary, mainly from the cultivated areas. The reason is that their main activities are near the village, and primary forests are of difficult and restricted access. The plant with the most numerous uses, bamboo, can be found everywhere near the habitations. Rice fields, Acacia and rubber plantations and home gardens are places where villagers can find a lot of useful plants, mainly for fodder, medicine and food. Very few species (only four) are not substitutable for the usage villagers have of it, and local people are no longer relying as much on forest products for their livelihoods as they once did, since their subsistence activities have recently diversified, even if some forest products are still used. 


\section{Local perspectives on conservation}

From the previous sections of this report it is apparent that biodiversity is high in the Khe Tran area and that natural resources still play an important role in local people's livelihoods. During our survey we observed that villagers gather these products from wild and domesticated sources and sometime even purchase them. Even if domesticated sources are perceived as the most important product sources, many products from the natural forest are still collected for several uses. In all, 134 plant and 29 animal species are considered important species of the forest (see Site description, Chapter 5).

Considering the presence of a conservation area close to the village, local people's relations to their natural environment, and the ban on extractive activities in the reserve, we organized a small workshop with the villagers to better understand their perceptions concerning forest and biodiversity conservation as well as their perspectives and priorities concerning Phong Dien Nature Reserve development. The villagers were divided into two groups, according to the part of the village in which they live (lower and upper part of the village). The groups had more or less similar perspectives on the meaning of conservation (Table 30). Villagers from the lower part defined conservation as forest protection, which bans any activities that disturb it, such as hunting, logging, making fire or gold mining. They considered conservation more along its management perspectives, whereby all villagers should share responsibilities, with a task force available to solve urgent forest problems. Clear demarcation between conservation and production forests should be available, with a concrete management strategy at all levels. The upper village group also perceived conservation as forest protection, but they considered it according to their willingness to protect it and as an opportunity for employment.

Apart from the local definition of conservation, we asked both groups how they would imagine their life and activities in Khe Tran if there were no conservation area. Both groups agreed that, without a conservation area, they would have free 
access to the forest. The lower village group thought that they would also have free access to new places to settle and for their cattle, but that their lives would be more difficult, because they would be more dependent on forest resources (unless a governmental program gave them incentive to move away from extractive activities) and more vulnerable to natural hazards. The upper village group thought that they would have a hard time and poor life conditions; they would be obliged to move more often to open new gardens, and this option was linked, according to the local point of view, to the traditional use of shifting cultivation. Conservation is synonymous with more sedentary agricultural practices for the villagers.

For both groups the presence of the conservation area implied a better future, with more infrastructure facilities, domesticated products (plants and animals), better relationships among villagers and more employment opportunities.

These answers, even if conditioned and influenced by the position and vulnerability of the local people towards government policy, shows that conservation, according to their perception, means change, progress, education, new activities and the loss of the main traditional activities. Once again these answers have to be considered in their political and social context, taking into account the tendency of villagers to give a soothing discourse to outsiders (here, the scientists). But it affords perspectives on the way local people consider their future living at the edge of a conservation area, their opportunities and expectations.

Local people hope that, with the formation of Phong Dien Nature Reserve, they will acquire the right to participate in its management and they even expect to have a key role in coordination with the government staff in charge of reserve protection.

Villagers have a positive perception of conservation of forest and biodiversity, even if they worry about their right to collect natural resources in the future. Their interest in participating in reserve management depends on their expectation of financial compensation if they, for example, take part in the task force in charge of the control of the reserve. It is also a way to emphasize their land rights and to push the government to recognize these rights. They consider that a negotiated participation in reserve management will allow them to collect some forest resources, including timber, NTFPs and even the valuable eaglewood. 
Table 30. Villager's perceptions on conservation and Phong Dien Nature Reserve

\begin{tabular}{|c|c|c|}
\hline Perception & Lower part villagers & Upper part villagers \\
\hline $\begin{array}{l}\text { Definition of } \\
\text { conservation }\end{array}$ & $\begin{array}{l}\text { Forest area is protected; all hunting } \\
\text { of precious animals, logging, } \\
\text { setting of forest fires, gold mining } \\
\text { and trapping is banned } \\
\text { - Conservation area must be } \\
\text { considered as the work of all } \\
\text { people, with a task force that can } \\
\text { solve urgent cases } \\
\text { There must be a definite } \\
\text { demarcation between conservation } \\
\text { area and production/planted forest } \\
\text { In order to have good conservation } \\
\text { efforts, a concrete plan/program// } \\
\text { project/organization is required at } \\
\text { all levels }\end{array}$ & $\begin{array}{l}\text { - Forest and natural resources } \\
\text { are protected } \\
\text { - Hunting, setting fires, } \\
\text { logging, etc. is prohibited } \\
\text { - Conservation is very } \\
\text { important and it is the job of } \\
\text { both state and local people } \\
\text { - Local people will have } \\
\text { employment from } \\
\text { conservation area activities }\end{array}$ \\
\hline $\begin{array}{l}\text { Life with } \\
\text { conservation }\end{array}$ & $\begin{array}{l}\text { - Will stabilize their life } \\
\text { - Forbidden from entrance to forest } \\
\text { and clearing for cultivation. More } \\
\text { focus on planting forest; better } \\
\text { income from production forest } \\
\text { harvesting } \\
\text { - Will establish cattle facilities } \\
\text { - Gain better awareness of forest and } \\
\text { - literacy standard } \\
\text { - Better infrastructure } \\
\text { people relationships among local } \\
\end{array}$ & $\begin{array}{l}\text { - Conservation brings } \\
\text { brighter future and offers } \\
\text { employment } \\
\text { - Focus on planting and } \\
\text { tending forest, animal } \\
\text { husbandry } \\
\text { - More state projects; better } \\
\text { infrastructure (roads, etc.) }\end{array}$ \\
\hline $\begin{array}{l}\text { Life without } \\
\text { conservation }\end{array}$ & $\begin{array}{l}\text { Free access to forest, clearance to } \\
\text { search for metals, for cultivation, } \\
\text { logging and trapping (hunting) } \\
\text { - Free migration (movement to other } \\
\text { locations) } \\
\text { - Free grazing of cattle } \\
\text { - Low awareness of natural disasters } \\
\text { - Local life is dependent on forest }\end{array}$ & $\begin{array}{l}\text { Free access to forest, e.g. } \\
\text { cattle grazing, hunting and } \\
\text { clearing for cultivation } \\
\text { - Life is hard and poor } \\
\text { - People had to move to } \\
\text { different places several } \\
\text { times annually } \\
\text { - More efforts on planting } \\
\text { forest for younger } \\
\text { generations }\end{array}$ \\
\hline $\begin{array}{l}\text { Role to play } \\
\text { in future } \\
\text { management } \\
\text { of Phong } \\
\text { Dien Natural } \\
\text { Reserve area }\end{array}$ & $\begin{array}{l}\text { Have the right to manage/protect } \\
\text { the reserve and receive a subsidy } \\
\text { - In general, management should rest } \\
\text { in the cooperation of staff in charge } \\
\text { and local people, with a permanent } \\
\text { task force } \\
\text { - Local people may collect NTFPs }\end{array}$ & $\begin{array}{l}\text { - Every person has to protect } \\
\text { the forest (including its } \\
\text { animals) } \\
\text { - Local people want to be } \\
\text { staff that look after the } \\
\text { conservation area } \\
\text { - Hope to establish a } \\
\text { conservation organization in } \\
\text { Khe Tran and make Phong } \\
\text { Dien Reserve an area of rich } \\
\text { biodiversity and beauty }\end{array}$ \\
\hline
\end{tabular}


These results show that the local people want to be part of the conservation process and not just be considered an external threat that should be banned from any extractive activity. Recognition of their rights, negotiation on the possibility to collect forest products and emphasis on local people's responsibility for their own land should be considered important elements of a successful conservation effort in Khe Tran.

\section{Summary}

Even if sometimes they are following the 'official' position on biodiversity conservation and its definition, villagers explained that they would like to be part of the process, for various reasons: to get access to resources, to enhance their rights to the land, to get payment for the activities they would perform for the FPD. By doing so, local people expect to be able to negotiate with the government the sustainable use of a number of resources, mainly NTFPs, but some logging and game hunting too. They want to collaborate with conservation institutions and to preserve the forest for the future and as a safety net, since they do not strongly rely on forest resource anymore. 


\section{Conclusion and recommendations}

In conclusion to the MLA activities implemented during this SDC-funded project, 'Stakeholders and biodiversity at the local level', we discuss the relevance of the method, summarize the main results of our surveys in the context of the different objectives of the project and provide recommendations in the Khe Tran village context.

\subsection{Conclusion}

\subsubsection{Relevance of MLA in a Vietnamese context}

If the overall project sought to strengthen local capacity to plan and implement locally relevant and viable forest landscape management, two objectives were particularly relevant to our MLA activities:

- to develop appropriate mechanisms for integrating local perceptions and views in decision making and planning; and

- to facilitate greater involvement of local people and other stakeholders in decision making and planning at the local level.

We proposed, by our activities, to test a set of tools, the MLA, designed to study local perception of landscapes and natural resources in the local context, a small village in rural Central Vietnam.

We are now able to confirm that the MLA tool was relevant to this kind of study and provided valuable information on the local management of natural resources. It was adapted to the Khe Tran context, where forest has been disturbed and no longer plays the role it used to play in local livelihoods. Plot sampling, because it records both tree and non-tree specimens, can be used in various environments: forests, plantations or even rice fields. The socio-economic data and the information about local perception gained through scoring exercises and 
participatory mapping are also relevant to a context where local people have shifted from forest-oriented activities to more sedentary agriculture. They show the evolution and transformation of the local people's priorities and knowledge on natural resources. The set of methods used during our survey provided a large set of data and results on Khe Tran villagers and their perspectives and options concerning the management of the future Phong Dien Nature Reserve.

An important database is available containing the data we collected through 11 plot samplings and 20 household surveys undertaken in Khe Tran on ethnobotany, forest landscapes characterization, local importance of natural resources and all socio-economic data necessary to the project achievement. This database helps us to provide an overview of the forest condition and on how forests still influence the local livelihood of the Pahy.

Soil analysis, which could not be implemented in the frame of our activities for logistical reasons, may provide relevant information on land suitability for the different land use options proposed by the government to the local people.

The MLA survey and the participatory development of future scenarios have also helped to facilitate discussions with local villagers about their options in the context of living at the edge of a nature reserve. The results of these discussions provide an informed case study and can help the government to make betterinformed decisions on Khe Tran-specific land and forest management. A June 2006 workshop in Thua Thien Hue will give us the opportunity to share this information with provincial and local institutions. During the workshop we will report the project results at the provincial and local levels. We will present the results to government agencies, nongovernmental organizations and villagers, and we will collect feedback on the way these results, and more generally the MLA set of tools, can be used by each participant in the frame of their own activities and projects in Vietnam.

Based on previous presentation and on interactions with various stakeholders during project implementation, it is clear that the method has already raised interest.

- District and commune officers consider MLA a valuable source of information on socio-economy, land use and local point of view on land management.

- Educational institutions such as the Hue University of Agriculture and Forestry have expressed interest to integrate the method into their curriculum.

- Conservation institutions such as the FPD consider MLA a valuable source of information for future forest land allocation, natural resource management and forest conservation.

- The international nongovernmental organizations Helvetas, SNV (Netherland Development Organization), TBI and WWF consider it an interesting way to gather information on local perceptions and priorities in the context of their own projects. Some partners have argued that a systematic implementation might be difficult in Vietnam because the land use planning and land allocation processes are already following specific procedures and because some parts of MLA may be considered time consuming and dependent on specialized expertise. Nevertheless they have expressed interest to compare the results 
collected by this method with their own information on community forestry, community-based natural resource management and land allocation.

- The Vietnamese participants in the surveys have also expressed great interest in and enthusiasm for the set of methods, the important information it generates and the strong relationship with local people it helps to build. Some of the participants working in government institutions such as FIPI, Department of Foreign Affairs, HUAF (Hue University of Agriculture and Forestry) and Tay Nguyen University have expressed the desire to use the methods in their own projects in other places in the province and in the rest of Vietnam, as they find that MLA provides relevant data on local priorities related to land allocation in the country.

More generally, in Vietnam, the government increasingly gives local people the right to manage the forests, even if recognition of local people's rights is still limited, as is the consideration of local knowledge and perspectives in that rapidly changing context. The government still makes decisions on land use planning following a relatively rigid top-down approach. In this context, MLA provides a relevant set of tools that can be selectively utilized in situations where stakeholders and especially decision makers want to become better informed on the perspectives of the local people on the important issues of forest land management, reforestation and allocation.

The results of our survey were also used as a basis for follow-up activities in Khe Tran, in the frame of the Future Scenario part of this SDC project (Evans, 2006). The information provided by MLA activities and the good relationship we built with the villagers were important contributions to the success of Future Scenario activities.

\subsubsection{Main results of our surveys}

The status of forest in Khe Tran has changed within the last 13 years from productive forest to watershed protection forest, which is planned to become part of Phong Dien Nature Reserve in 2010 because of its high biodiversity. The war, logging activities and agricultural practices have deeply disturbed the forest landscape. In the frame of the future reserve, local people have been banned from most of the extractive activity in the natural forest. The government has proposed to develop other activities to provide income to each household. In this context, rubber and Acacia plantation programs are supposed to provide cash income to villagers.

The village is characterized by the presence of a strong minority group, the Pahy, mixed with other groups. The villagers moved away during the war, and they were authorized to resettle in their village only after the conflict ended. They routinely spend a large amount of time in their gardens, rice fields and plantations. The village is divided into two areas, the upper part, where villagers have lower incomes and depend on home gardens and Acacia plantations for their livelihoods, and the lower part, with a higher mean income and depending on more diversified crop cultivation, including rubber and rice. 
Among the eight main land covers, forests are divided into three categories: big tree forests, small tree forests and plantations. The fact that villagers include plantations in the forest category seems related to the official forest status of plantation lands. Species richness is high in Khe Tran and even potentially monotonous land cover types such as plantations or rice fields still have high nontree diversity, which enables and maintains their multiuse function. Villagers still use a wide range of species for their livelihoods, partly from the natural forests but, under present conditions, mainly from the cultivated areas.

Participatory mapping also showed that knowledge on forest products, wildlife and other natural resources is still important for villagers, even if this knowledge tends to be limited in diversity of resources and in area covered. Apart from this ethno-botanical knowledge, we found that villagers also have a strong sense of ownership when they discuss land tenure in the village, repartition of plantation responsibilities and expectations for the future. Local people represent no imminent threat to the recorded endangered species. The direct impact of human activities on forest cover at present cannot be quantified based on our sampling.

Forest, including natural forest and plantations, is the most important landscape element for all the villagers for all the products that can be collected from it. Perceptions of forest types vary by gender and according to accessibility and activities performed. For men, plantation is the most important category because of the economic benefits, while for women it is natural forest because of the diversity of NTFPs encountered.

With respect to different time frames, forest in the present (including plantations) is the least important, because of the actual resources depletion, the government ban on all natural resource collection in the forest and the actual alternative activities. Forest of the past is considered more important, because of all the activities that were possible then. Domesticated resources are considered more important than any other category, wild or purchased. The government policy on the PDNR has affected dependency on forest resources.

Even if the knowledge on natural resources is still important considering the new management activities, we observe that the knowledge on forest is progressively decreasing. Local people still recognize the different roles of the forest in general, but have difficulty to provide information on specific resources.

A big contribution to conservation could be realized by integrating the local point of view into it and by preserving the local knowledge. The main threat identified by villagers is logging, followed by forest fires. This ranking shows that there is awareness of the risks for the forest, but also for local livelihoods, of engaging in unsustainable activities.

The villagers explained that they would like to be part of the conservation process, for various reasons: to get access to the resources, to enhance their rights to the land, to get payment for the activities they would perform for the FPD. They expect also to be able to negotiate the use of some of the resources, mainly NTFPs, but logging as well. They want to collaborate with conservation institutions, not only for the reasons mentioned above, but also to keep the forest as a safety net for the future. 


\subsection{Recommendations}

The following recommendations are based on the results of our survey, and are taking into account the different objectives of the project. More specifically, these recommendations concern potential follow-up in Khe Tran and the possibility of more closely involving the local population in conservation management and other land use planning. Government and other development agencies may use them to analyse the role of local stakeholders in forest management.

\subsubsection{Community forestry and forest management}

- Community forestry should be considered an interesting option for involving local people in reserve management by involving them in more sustainable activities.

- More, and longer-term, targeted studies of the different categories of land cover would help to gain more comprehensive information on the forest conditions in and near Khe Tran and on the local knowledge and priorities concerning forest conservation and management. This would necessitate closer involvement in the daily life of the Pahy, the possibility to stay for longer periods in the villages and authorization to travel to less accessible forests located farther from the village in the core zone of the reserve.

\subsubsection{Land tenure}

- Land tenure remains a sensitive issue, even if initiatives are undertaken by the government to recognize the rights of local communities on their land. Especially concerning plantations, land tenure should be secured so that the local community does not have to rely only on limited contracts to exploit these lands.

\subsubsection{Conservation}

- Involvement in management. Local people should be more directly involved in conservation area management. At the moment, they only have to follow the rules designed by government and conservation agencies, and they are not allowed to perform any extractive activity in forest proximate to or within the nature reserve. Local people represent a human resource that can be useful for the reserve (in the fight against poachers and illegal loggers, for example). The local interest clearly was direct participation in reserve administration activities, through jobs.

- Involvement in negotiations. We recommend that information on threatened species be given to villagers to raise the awareness of conservation needs. The specific uses of especially threatened species should be discussed in order to give people the option of choosing other species for these uses.

- Zonation in the reserve. Traditionally a part of the reserve has belonged to the local community, and villagers should not be kept away from their territory 
but be part of the decisions concerning its sustainable management. Local people should be given more rights to collect and use forest products, through a negotiation process. Viewing the local people as part of the solution for conserving Phong Dien Nature Reserve is not yet an option for the government but they could help keep poachers away from the reserve. There should be an agreement on the possibility to access the forest, even that inside the nature reserve, during hard times (drought or flood) to collect some important forest products.

\subsubsection{Economic incentives}

- The danger of the new economic and subsistence activities (plantations, rice farming) is that they keep people away from more-traditional activities. Even if the Pahy society is changing, preserving its traditional roots and its bases should be an important condition in any attempt of integration into other economic systems.

- Decisions should be made on the diversification of agricultural practices (aquaculture, etc.). The profitability of plantations depends on market fluctuation and they should not be taken as the sole alternative to shifting cultivation and extractive activities in the forest.

- The current new economic activities (especially plantations) are unsecured. Since most of the land around the village has been converted, few options are left to villagers in case of an economic crisis.

\subsubsection{Cultural identity and local knowledge}

- The political process of integration of the Pahy minority group into the lowland way of life carries the danger of loss of cultural identity. Even if the integration of other ethnic groups into Pahy society is a slow process, these communities bring with them new behaviours, new activities and relationships with the local government.

- Emphasis should be placed on tapping the existing (remaining) local knowledge of the village community. More studies should be implemented to collect information on local skills, and the traditional knowledge should be sustained.

- Further research on the sustainability of NTFP collection is necessary, as an option for sustainable use of forest resources. Most of the natural vegetation in Khe Tran is disturbed forest or shrub lands, and the impacts of floods and fires continue to influence forest cover and structure. 


\section{Bibliography}

Appraisal Mission. 2004. Thua Thien Hue rural development programme II: programme framework document. Post Appraisal Revision. (http://global. finland.fi/english/procurement/ThuaThienHue/pd_viet_tthII.pdf)

Artemiev, Igor. 2003. State forestry enterprise reform in Vietnam: unlocking the potential for commercial wood growing. Technical note. Rural Development and Natural Resources East Asia and Pacific Region.

Asian Development Bank (ADB). 2005. Ethnic minority development plan for Central region water resources project. ADB VIE 30292. (http://www.adb. org/Documents/IndigenousPeoples/VIE/EMDP-CRWR.pdf)

Barney, Keith. 2005. Central plans and global exports: Tracking Vietnam's Forestry Commodity Chains and Export Links to China. Forest Trend. (http://www. forest-trends.org/documents/publications/Vietnam\%20Final\%20Report $\% 20$ 7-1-05.pdf)

Evans, Kristen. 2006. Evaluating and Adapting Future Scenarios in ForestDependent Communities in Hue Province, Vietnam.

Le Thanh Chien. 1996. Trial planting of Cinnamomum cassia for high essential oil productivity from the leaves. Forest Science Institute of Vietnam, Hanoi.

Forest Inventory and Planning Institute (FIPI). 1996. Vietnam Forest Trees. Agricultural Publishing House, Hanoi.

Gordon, Raymond G., Jr. (ed.) 2005. Ethnologue: Languages of the world, 15th edition. SIL International, Dallas, TX, USA. (http://www.ethnologue.com/)

Chinese Academy of Science, Institute of Plant Research. 1972-1976. Iconographia Cormophytorum Sinicorum. Volume $1-5$. Since Press. Beijing. (Zhongguo Gaodeng Zhiwu Tujian, Kexue Chubanshe:1-5 Beijing)

IUCN. 2006. IUCN red list of threatened species. http://www.iucnredlist.org/ 
Le Van Lan, S. Ziegler, and T. Grever. 2002. Utilization of forest products and environmental services in Bach Ma National Park, Vietnam. http://www. mekong-protected-areas.org/vietnam/docs/bach_ma_forest_products.pdf

Mabberley, D.J. 1997. The plant-book: a portable dictionary of the vascular plants. Cambridge University Press, Cambridge, UK.

Maltsoglou, Irini and George Rapsomanikis. 2005. The contribution of livestock to household income in Vietnam: a household typology based analysis. PPLPI Working Paper No. 21. FAO. (http://www.fao.org/ag/AGAinfo/projects/en/ pplpi/docarc/wp21.pdf)

Matarasso, Michael and Do Thi Thanh Huyen. 2005. Community participation for conservation success: promoting effective conservation of Vietnam's natural heritage through community-based environmental education. Final Progress Report. WWF Indochina Environmental Education Unit, Vietnam.

Oudhia, Pankaj. 2004. Kans (Saccharum spontaneum L.). http://www.hort.purdue. edu/newcrop/CropFactSheets/kans.html

Pham Hoang Ho. 1993. Cây cỏ Việt Nam. Volume 1-6. Montreal.

Sheil, Douglas, Rajindra Puri, Imam Basuki, Miriam van Heist, Meilinda Wan, Nining Liswanti, Rukmiyati, Mustofa A. Sardjono, Ismayadi Samsoedin, Kade Sidiyasa, Chrisandini, Edi Permana, Eddy M. Angi, Franz Gatzweiler, Brook Johnson, Akhmad Wijaya. 2003. Exploring biological diversity, environment and local people's perspectives in forest landscapes, 2nd revised and updated edition. Center for International for Forestry Research, Ministry of Forestry and International Tropical Timber Organization, Bogor, Indonesia.

Le Trong Trai, Tran Hieu Minh, Tran Quang Ngoc, Tran Quoc Dung and Ross Hughes. 2001. An investment plan for the establishment of Phong Dien Nature Reserve, Thua Thien Hue Province, Vietnam. BirdLife International Vietnam Program and the Forest Inventory and Planning Institute, Hanoi, Vietnam.

Vu Hoai Minh and Hans Warfvinge. 2002. Issues in management of natural forests by households and local communities of three provinces in Viet Nam: Hoa Binh, Nghe An, and Thua Thien Hue. Asia Forest Network; Working Paper Series vol 5, California. 47p.

WCMC. 1994. Biodiversity profile of the Socialist Republic of Viet Nam. Appendix 5: threatened plant species. (http://www.wcmc.org.uk/infoserv/ countryp/vietnam/app5.html)

Yukio, Ikemoto. 2001. Poverty alleviation policies and ethnic minority people in Vietnam. Conference Justice and Poverty: Examining Sen's Capability Approach, Cambridge, 5-7 June 2001. (http://www.st-edmunds.cam.ac.uk/ vhi/sen/papers/ikemoto.pdf )

Yunnan Shumu Tuzhi, 1990. Yunnan Kexue Chubanshe, Kunming. 


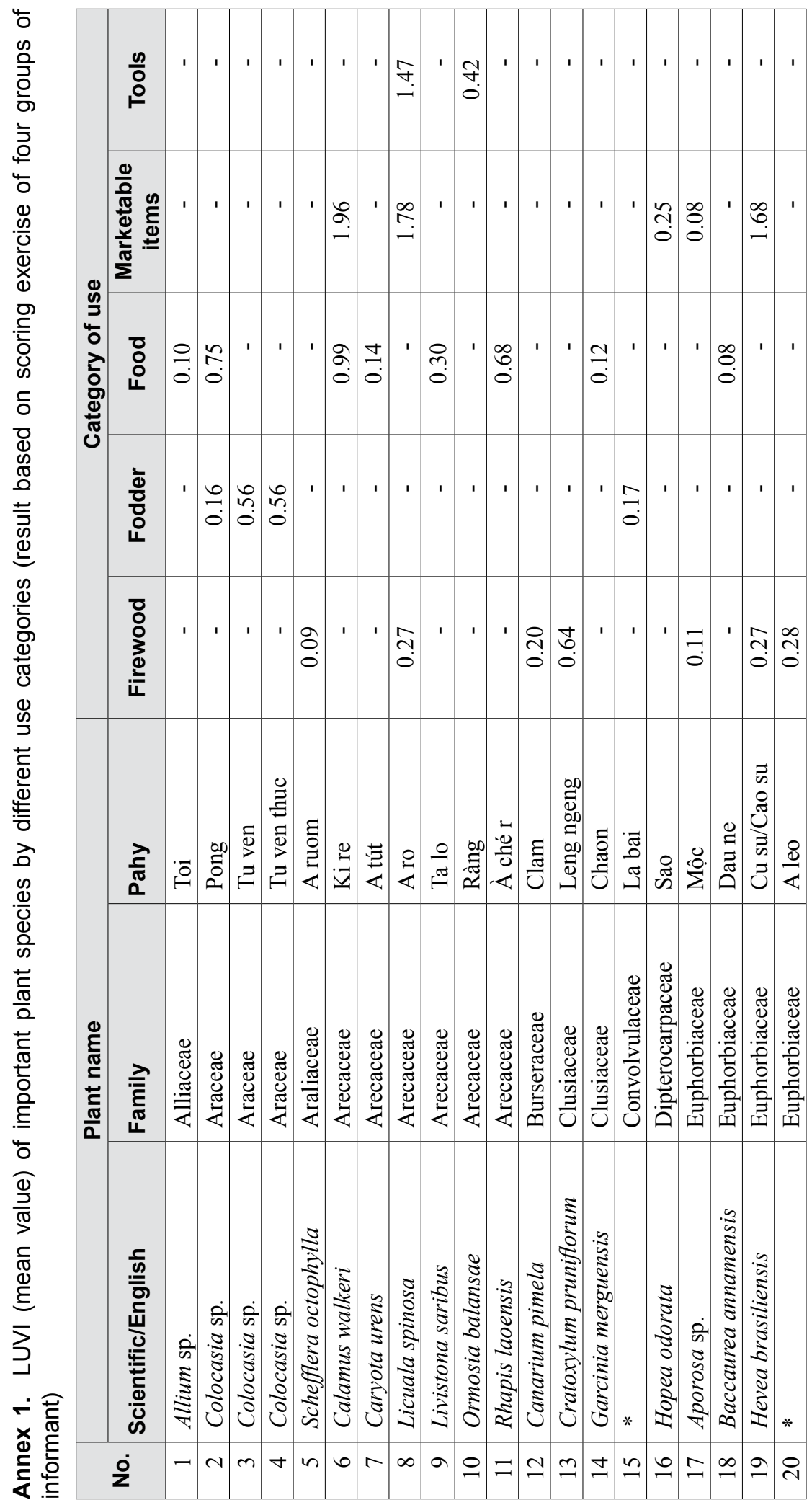




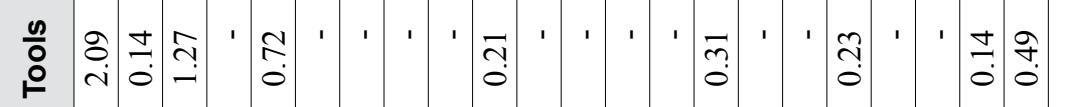

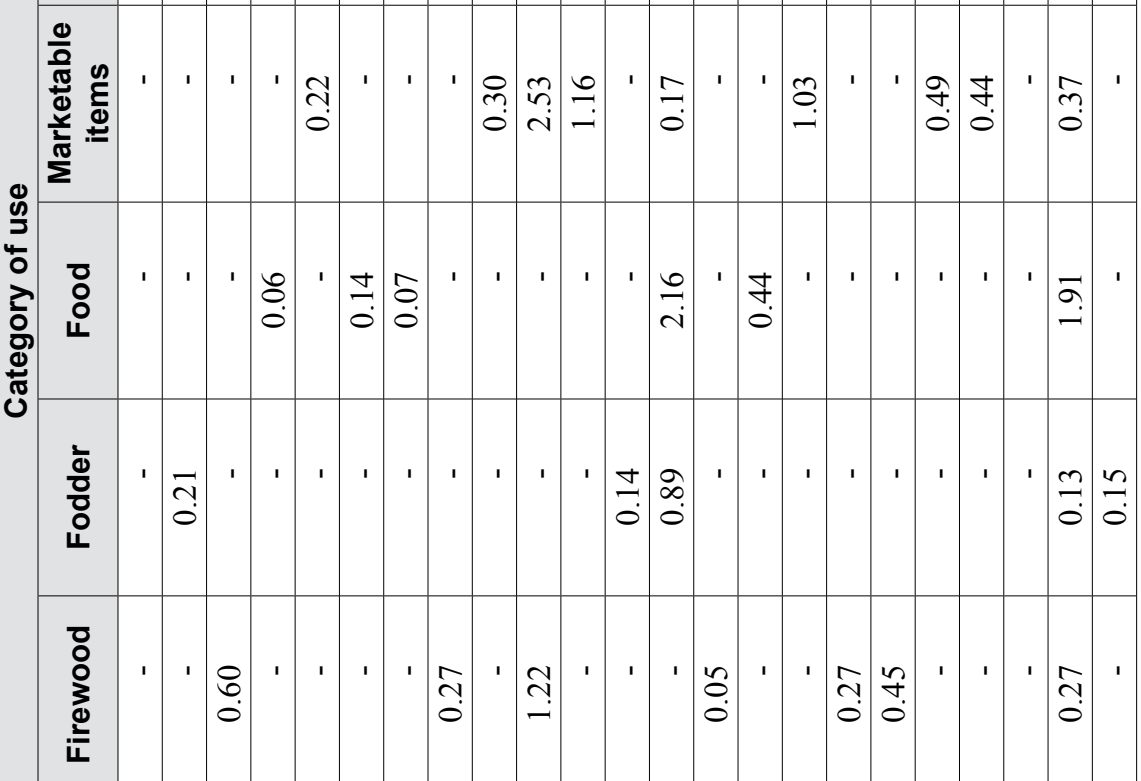

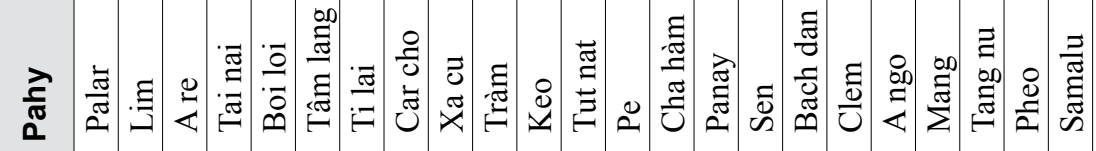

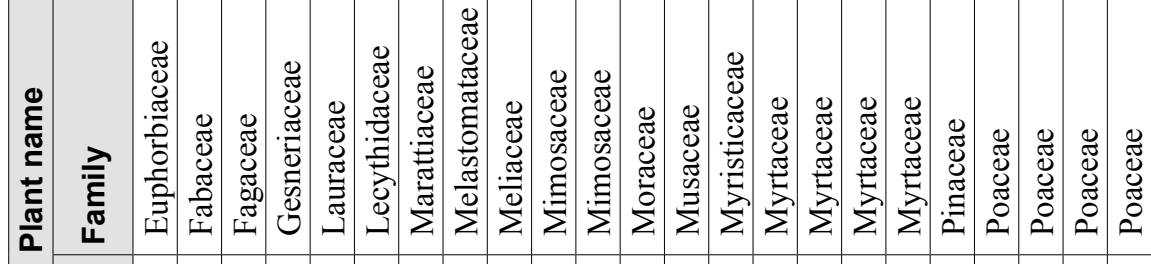

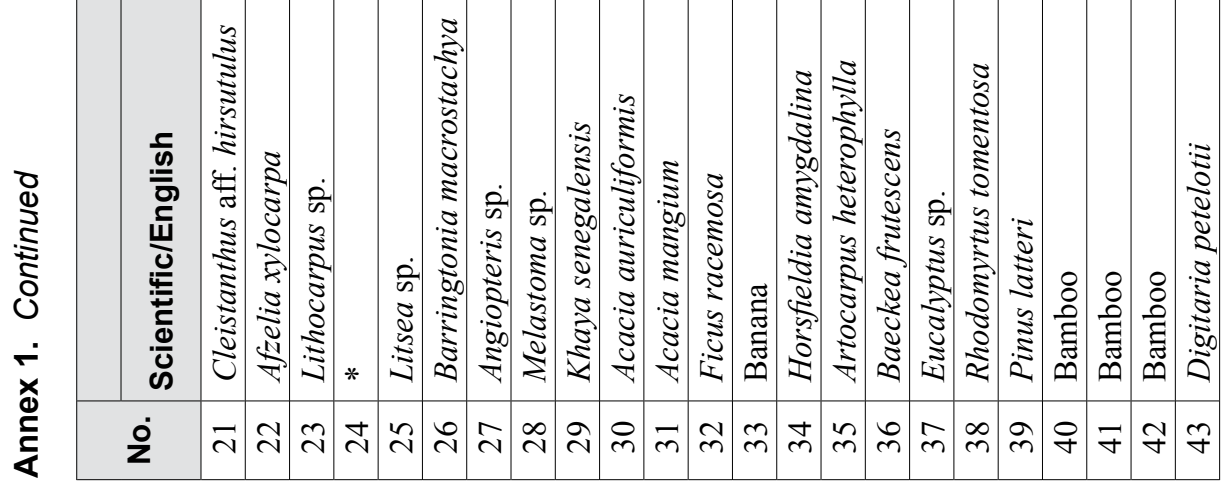




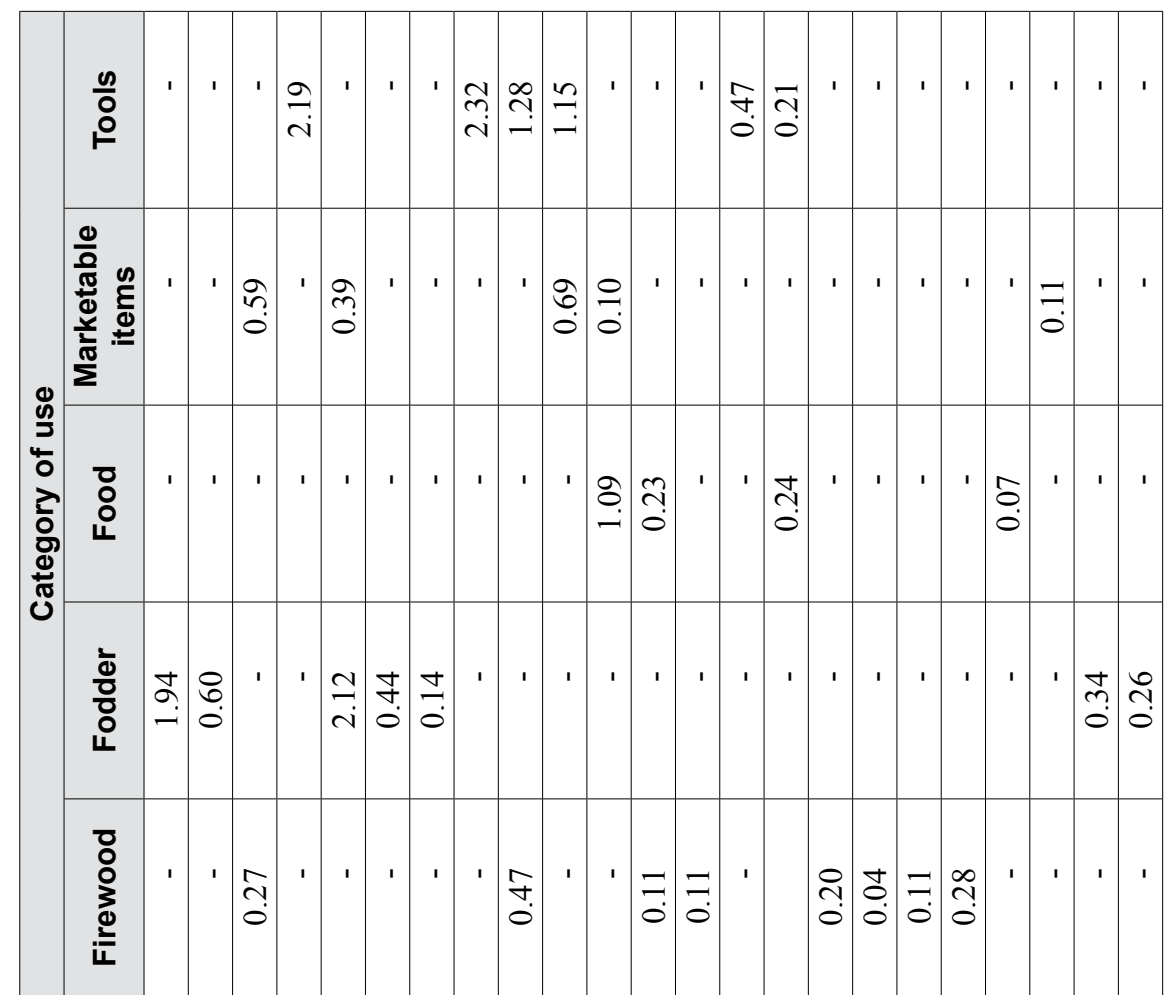

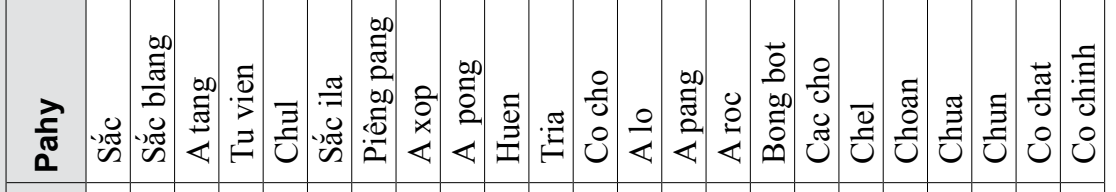
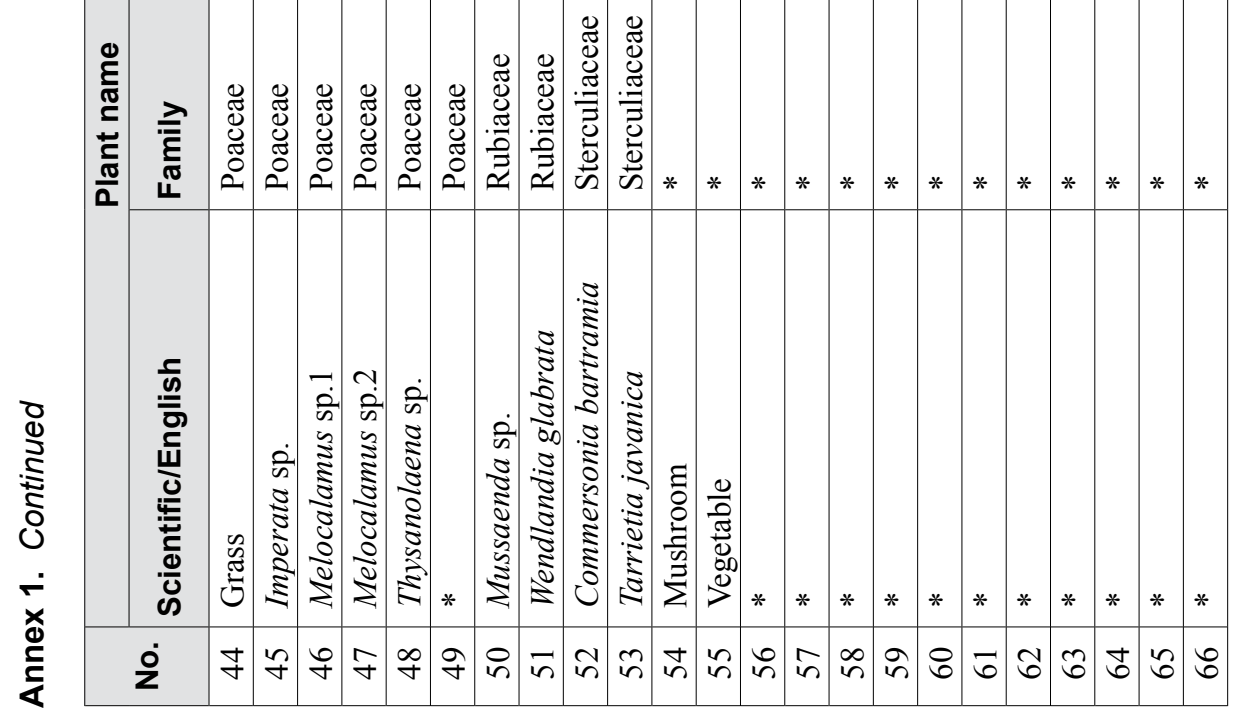


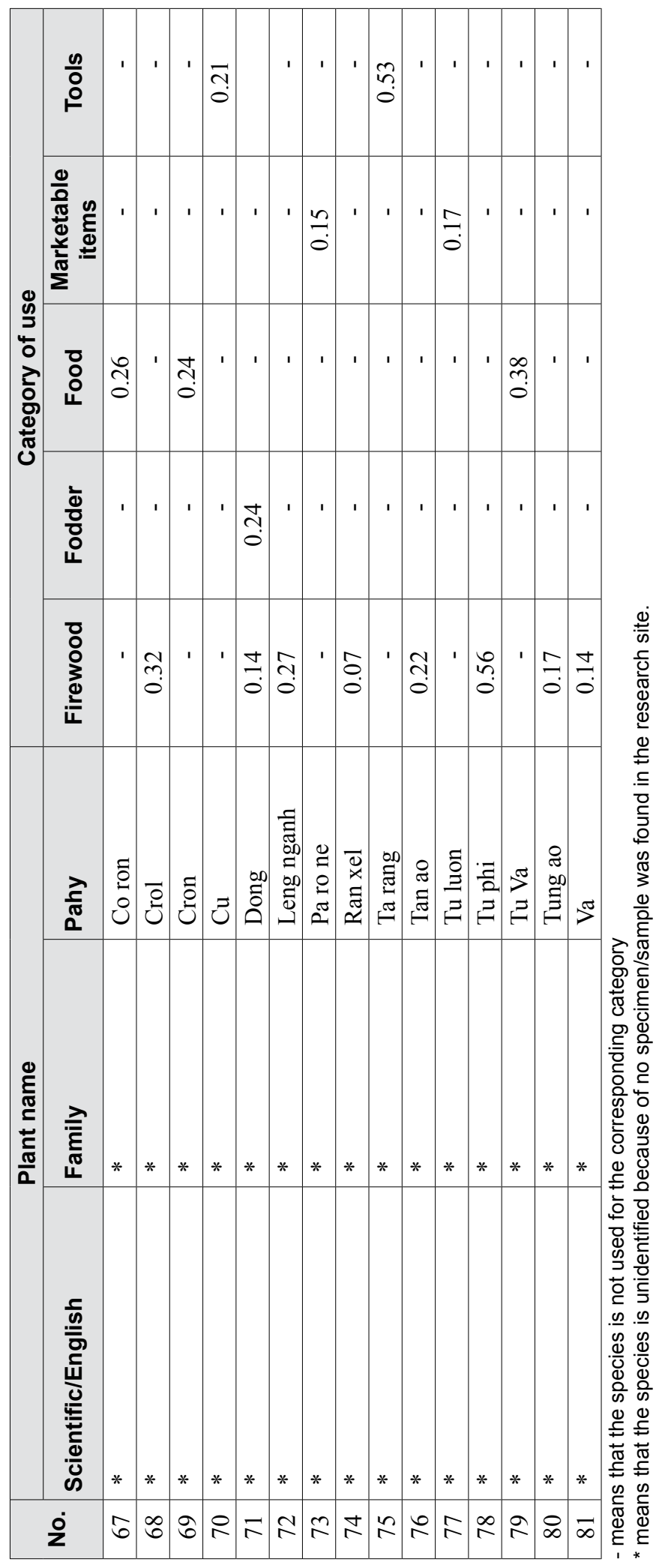


Annex 2. LUVI (mean value) of important animal species by different use categories based on scoring exercise of four groups of informant

\begin{tabular}{|r|l|l|r|r|r|c|}
\hline \multirow{2}{*}{ No. } & \multicolumn{2}{|c|}{ Animal name } & \multicolumn{4}{c|}{ Category of use } \\
\cline { 2 - 7 } & Pahy & English & Food & $\begin{array}{c}\text { Marketable } \\
\text { item }\end{array}$ & Medicine & Tools \\
\hline 1 & A at na & $*$ & 0.59 & - & - & - \\
\hline 2 & A binh & Rat & 1.95 & - & - & - \\
\hline 3 & A che & Bird & 0.02 & - & - & - \\
\hline 4 & A cuot & Frog & 0.89 & - & - & - \\
\hline 5 & A ut & $*$ & - & - & 0.44 & - \\
\hline 6 & Can chong & $*$ & - & - & 0.24 & - \\
\hline 7 & Chim chao mao & Bird & - & 0.14 & - & 0.03 \\
\hline 8 & Chim chich choe & Bird & - & & - & 0.03 \\
\hline 9 & Chim cuong & Peacock & - & 0.21 & - & 0.10 \\
\hline 10 & Chim sao & Bird & - & 0.20 & - & 0.04 \\
\hline 11 & Chon den & $*$ & 0.92 & - & - & - \\
\hline 12 & Co chong & $*$ & - & - & 0.17 & - \\
\hline 13 & Cu lui & $*$ & 0.14 & - & - & - \\
\hline 14 & Cu xanh & Snake & 0.02 & - & 0.12 & - \\
\hline 15 & Cuong & $*$ & - & - & - & 0.27 \\
\hline 16 & Dong & $*$ & - & - & - & 0.08 \\
\hline 17 & Hon & $*$ & - & - & 0.30 & - \\
\hline 18 & K chu & $*$ & - & 0.09 & - & 0.05 \\
\hline 19 & Khep & $*$ & - & - & 0.03 & - \\
\hline 20 & Khuou & Bird & - & 0.27 & - & 0.25 \\
\hline 21 & Kien & $*$ & 0.06 & - & - & - \\
\hline 22 & Kiep & $*$ & -0.08 & - & - & - \\
\hline 23 & Pi reo & $*$ & - & - & 0.29 \\
\hline 24 & Quai & - & - & - & - \\
\hline 25 & quai & - & - & 0.16 & - \\
\hline 26 & Tac ke & - & - & - & - \\
\hline 27 & Truoi & - & - & - & 0.07 \\
\hline 28 & Truon prieng & $*$ & - & & \\
\hline 29 & Vet & - & - & - & - \\
\hline & & - & - & - & - \\
\hline
\end{tabular}

- means that the species is not used for the corresponding category 


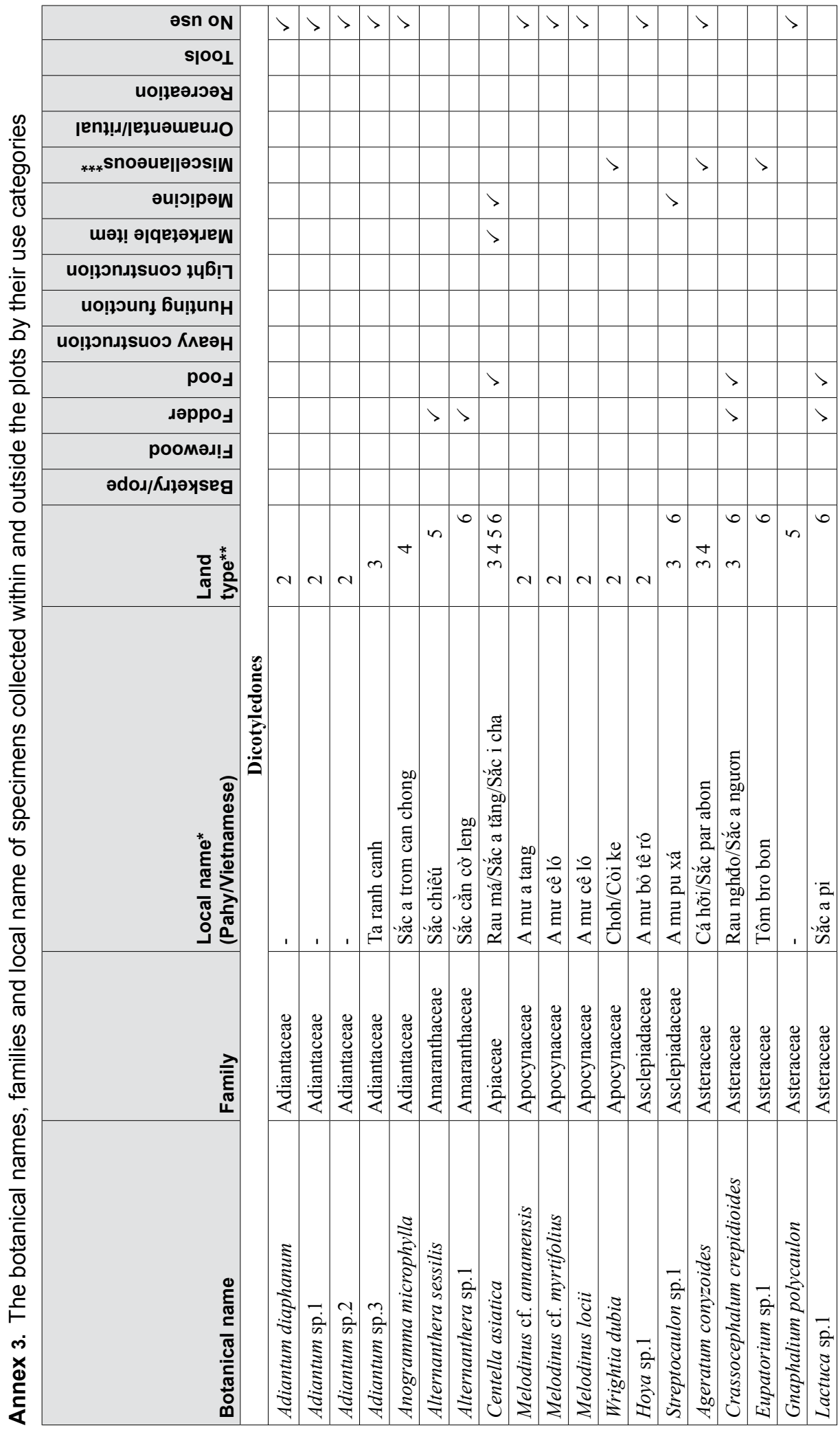




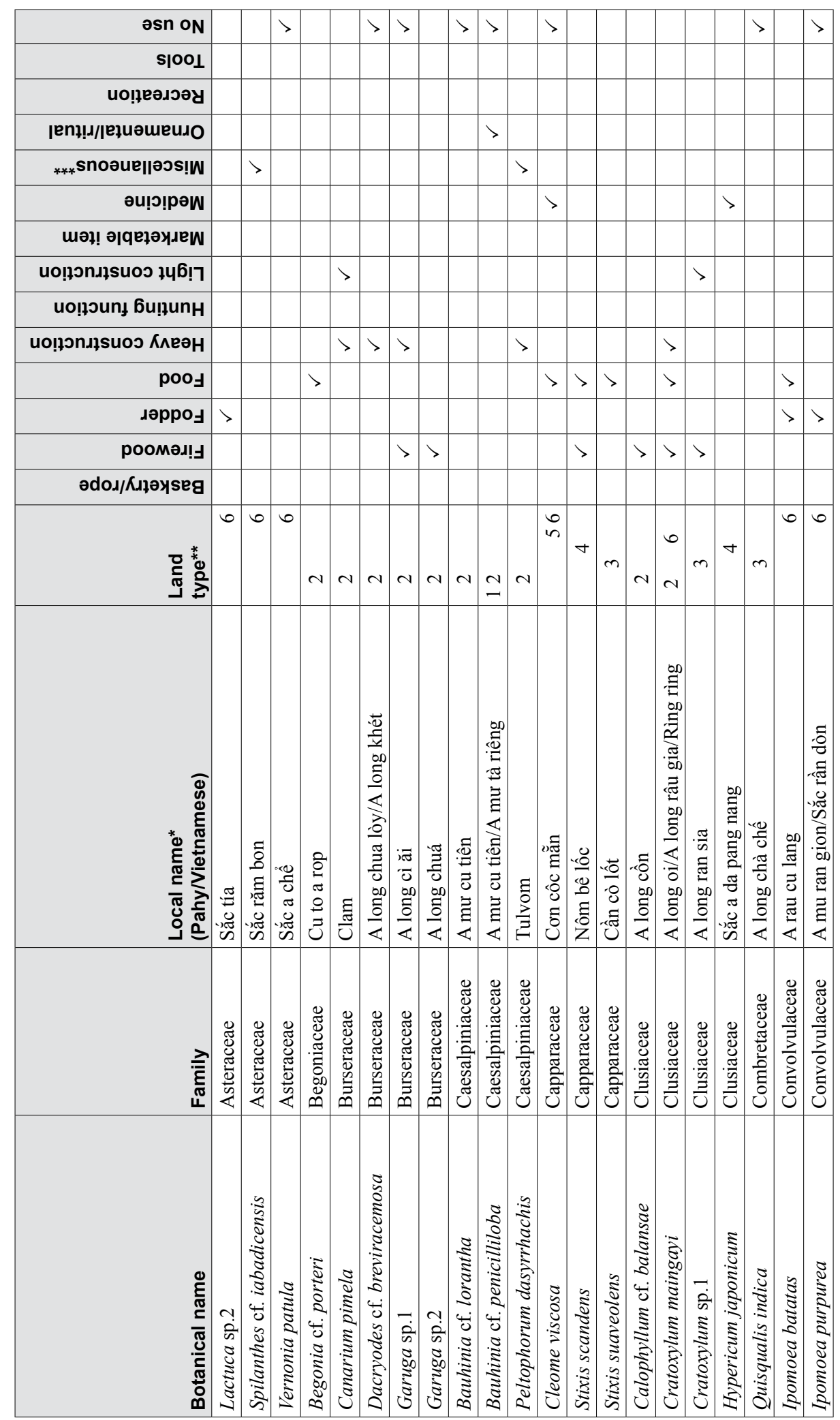




\begin{tabular}{|c|c|c|c|c|c|c|c|c|c|c|c|c|c|c|c|c|c|c|c|c|}
\hline əSn on & $>$ & $>$ & & & & & & & & & & & $>$ & & & & & & & \\
\hline s|OOL & & & & & & & & & $>$ & & & & & & & & & & & \\
\hline ио!̨еәдәәу & & & & & & & & & & & & & & & & & & & & \\
\hline ןenł!ג/ןеłuәшеихо & & & & & & & & & & & & & & & & & & & & \\
\hline${ }_{* * *}$ snoəue & & $>$ & & & & & & & & & & & & & & & & & & \\
\hline әu!̣!рәw & & $>$ & $>$ & & & & $>$ & & & & & & & & & $>$ & $>$ & & & $>$ \\
\hline 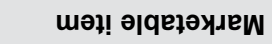 & & & & & & & & & & & & & & & $>$ & & & & & \\
\hline 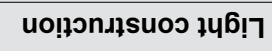 & & & & & & $>$ & & $>$ & & & & & & $>$ & & $>$ & & & & \\
\hline uo!̣oung 6u!łunH & & & & & & & & & & & & & & & & & & & & \\
\hline 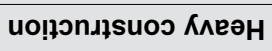 & & & & & & $>$ & & $>$ & & & & & & & & & & & & \\
\hline poos & & $>$ & & & & & & & & & & & & & & & & & & \\
\hline ләрроЈ & & & & & & & & & & & & & & & & & & & & \\
\hline роомәд!」 & $>$ & & & $>$ & $>$ & $>$ & $>$ & $>$ & $>$ & $>$ & $>$ & $>$ & & $>$ & & $>$ & & $>$ & $>$ & \\
\hline әdoג/Кıәәуseg & & & & & & & & & & & & & & & & & & & & \\
\hline ס & $\sim$ & $\cong$ & 0 & $\alpha$ & $a$ & - & $\nabla$ & 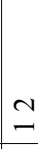 & $n$ & n & $\sim$ & n & in & $m$ & $m$ & $a$ & - & $\sim$ & $m$ & $m$ \\
\hline 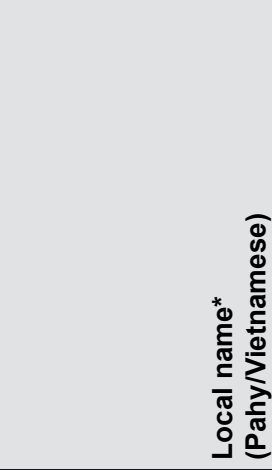 & $\begin{array}{c} \\
\\
: \\
2 \\
2\end{array}$ & 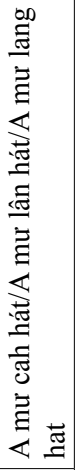 & 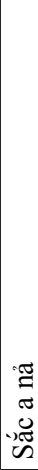 & ' & $\begin{array}{l}\frac{\pi}{0} \\
0 \\
0\end{array}$ & 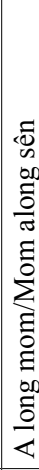 & 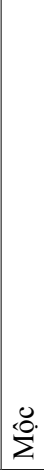 & 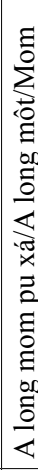 & 혀 & 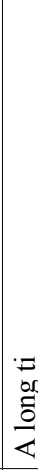 & 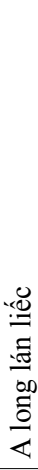 & 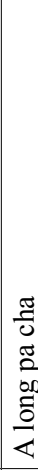 & & 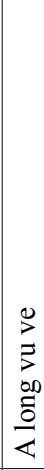 & 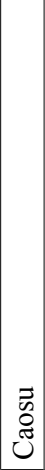 & 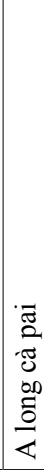 & 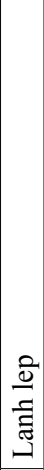 & 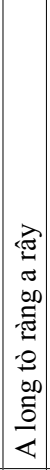 & 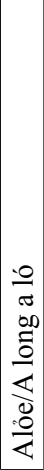 & 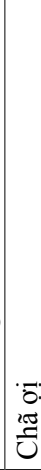 \\
\hline 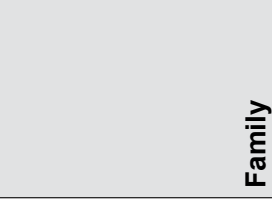 & 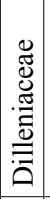 & 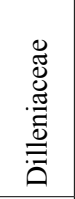 & 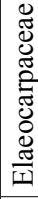 & 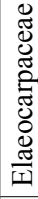 & 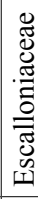 & 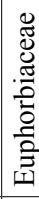 & 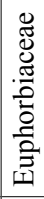 & 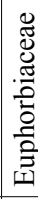 & 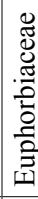 & 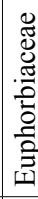 & 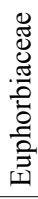 & 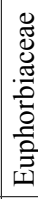 & 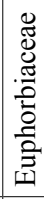 & 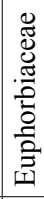 & 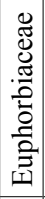 & 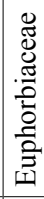 & 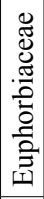 & 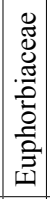 & 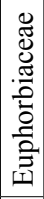 & 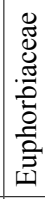 \\
\hline 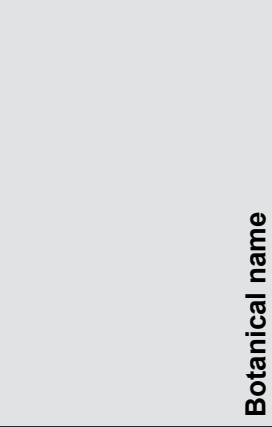 & 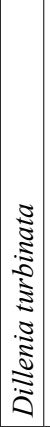 & 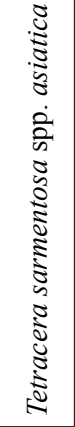 & 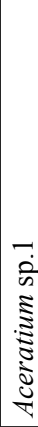 & 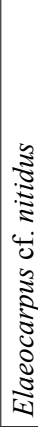 & 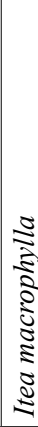 & 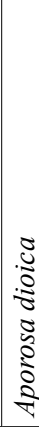 & 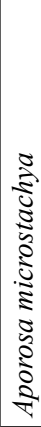 & 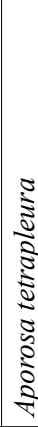 & 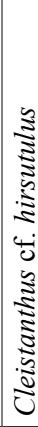 & 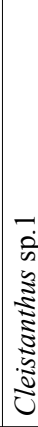 & 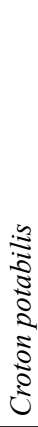 & 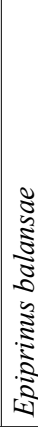 & 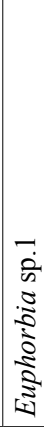 & 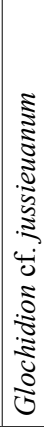 & 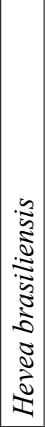 & 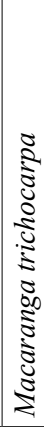 & 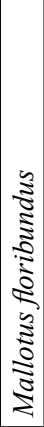 & 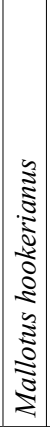 & 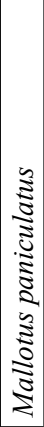 & 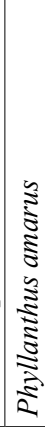 \\
\hline
\end{tabular}




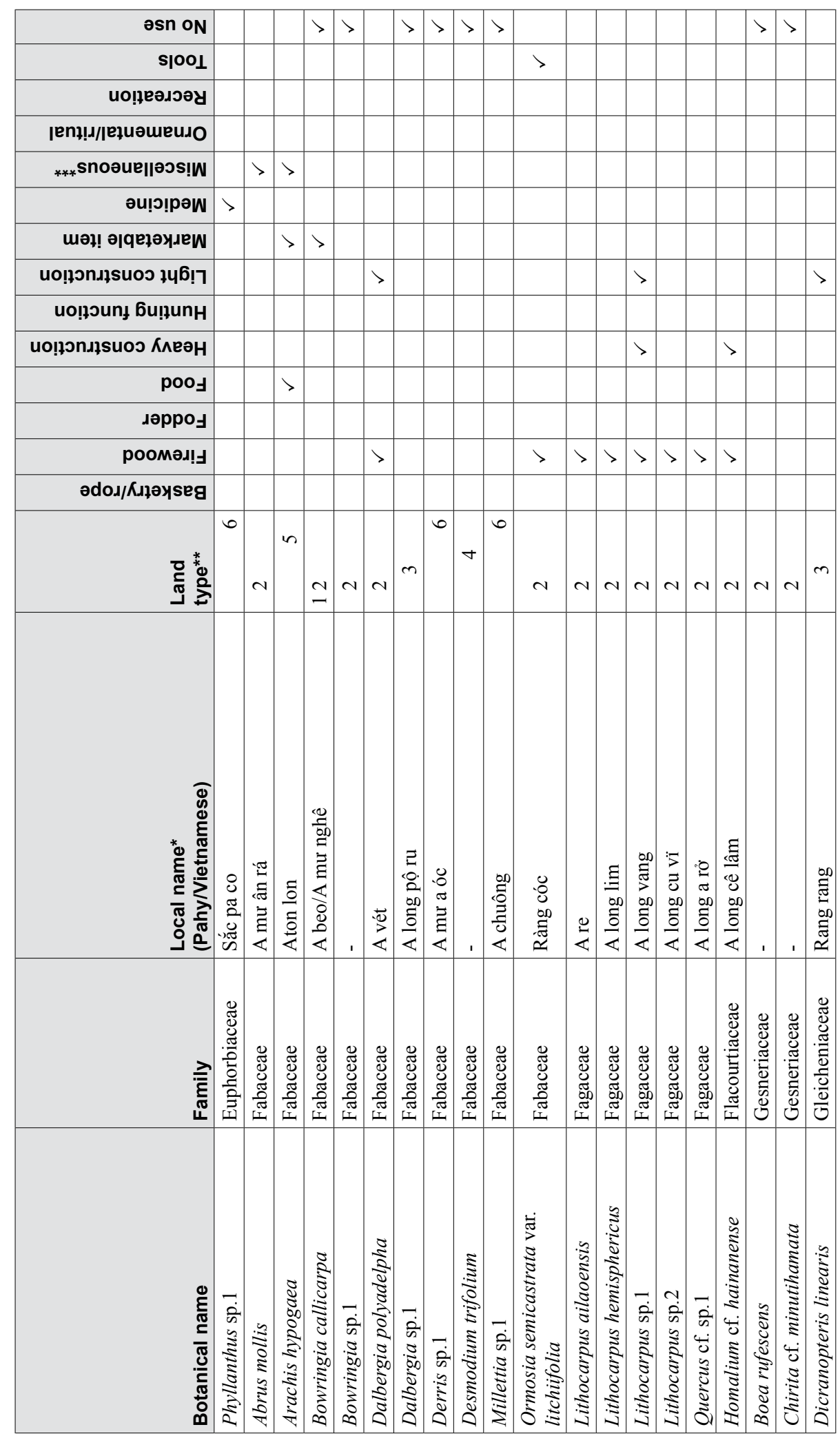




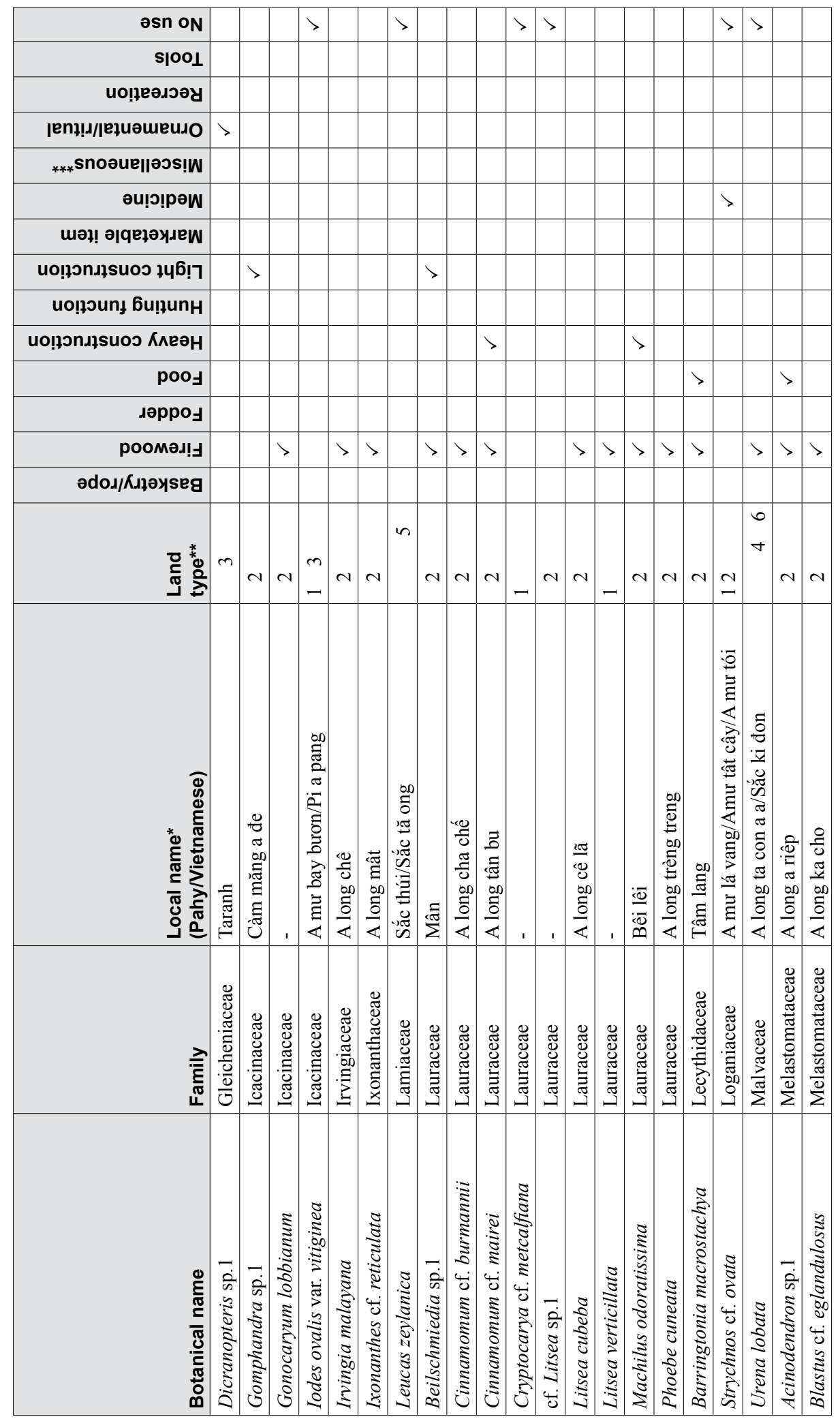




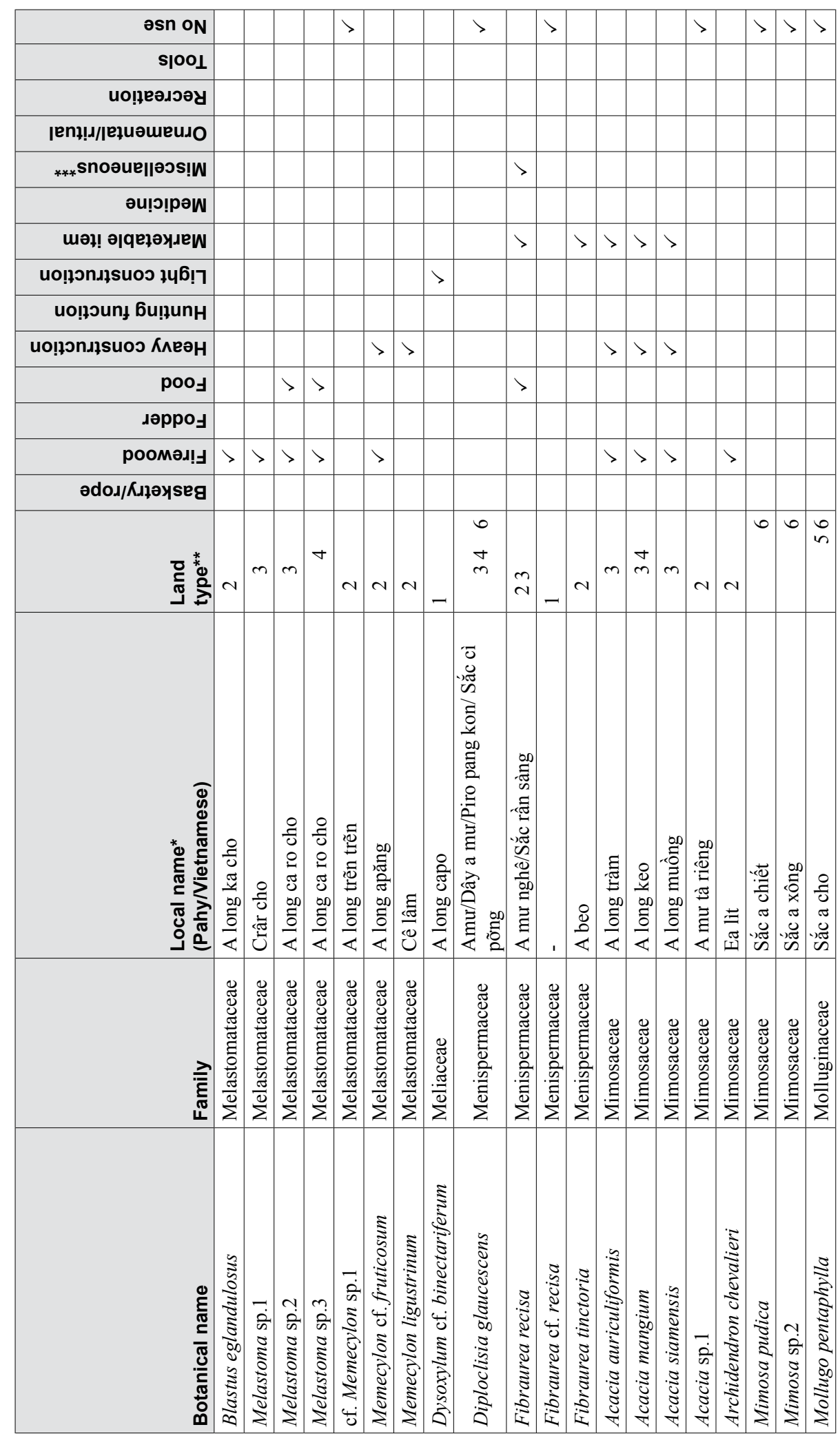




\begin{tabular}{|c|c|c|c|c|c|c|c|c|c|c|c|c|c|c|c|c|c|c|c|c|c|}
\hline əsn on & & & & & $>$ & & $>$ & $>$ & & & & $>$ & & & & & & & & & \\
\hline s|0o। & & & & & & & & & & & & & & & & & & & & & \\
\hline ио!̣еәдәәу & & & & & & & & & & & & & & & & & & & & & \\
\hline |епұ!ม/|еұиәшеило & & & & & & & & & & & & & & & & & & & & & \\
\hline${ }_{* * *}$ snoəue||əэs!W & & & & & & & & & & & & & & & & & & & & & \\
\hline әи!ற!рәW & & & & & & & & & $>$ & & & & & & & & & & & & \\
\hline 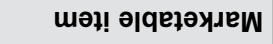 & & & & & & & & & & & & & & & & & & & & & \\
\hline 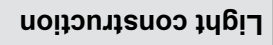 & $>$ & & & & & & & & $>$ & & & & & & & & & & & & \\
\hline uo!łoun, 6u!łunH & & & & & & & & & & & & & & & & & & & & & \\
\hline 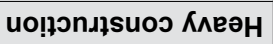 & $>$ & $>$ & $>$ & & & & & & & & & & & & & & & & $>$ & $>$ & $>$ \\
\hline poos & $>$ & $>$ & $>$ & $>$ & & & & & & & & & & & & & $>$ & & & & \\
\hline ләрро与 & & & & & & & & & & & & & & & & & & & & & \\
\hline роомәд! & $>$ & & & $>$ & & $>$ & & $>$ & & $>$ & $>$ & & $>$ & $>$ & $>$ & $>$ & $>$ & $>$ & & & \\
\hline 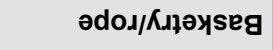 & & & & & & & & & & & & & & & & & & & & & \\
\hline 율 & 0 & $N$ & 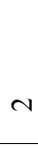 & - & $\sim$ & $m$ & a & 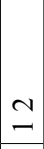 & $N$ & $N$ & $\sim$ & - & $m$ & $\nabla$ & 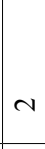 & $\sim$ & 0 & - & $N$ & 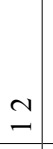 & N \\
\hline 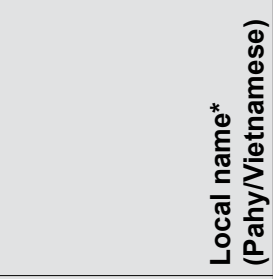 & 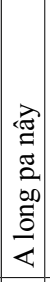 & 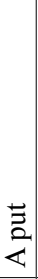 & 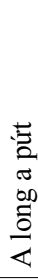 & $\begin{array}{l} \\
\overline{\mathscr{Z}} \\
\bar{U}\end{array}$ & 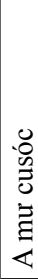 & 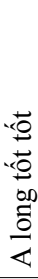 & 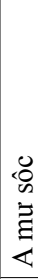 & 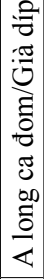 & $\begin{array}{c}1 \\
:=0 \\
0 \\
0\end{array}$ & 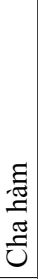 & 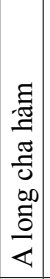 & , & $\mid \begin{array}{l}\tilde{0} \\
0 \\
00 \\
0 \\
0 \\
0\end{array}$ & 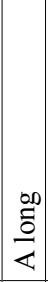 & 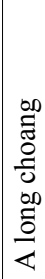 & $\begin{array}{c}0 \\
0 \\
0 \\
00 \\
-\Xi \\
0 \\
00 \\
0 \\
\frac{0}{<} \\
\end{array}$ & $\mid \begin{array}{l}0 \\
0 \\
\frac{0}{0} \\
0 \\
00 \\
00 \\
0 \\
2\end{array}$ & 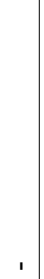 & 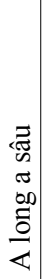 & 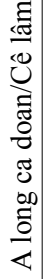 & 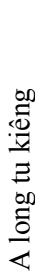 \\
\hline 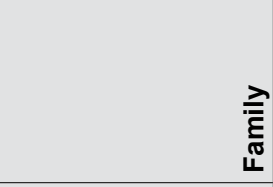 & 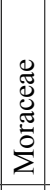 & $\begin{array}{l}\mathbb{\Xi} \\
\mathbb{J} \\
\mathbb{\Xi} \\
\stackrel{0}{\Delta} \\
\end{array}$ & 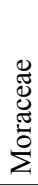 & 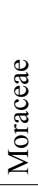 & 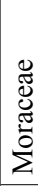 & 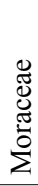 & 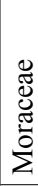 & 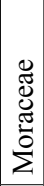 & 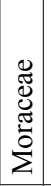 & 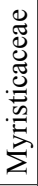 & 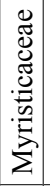 & 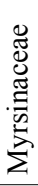 & 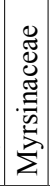 & 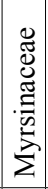 & 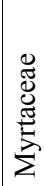 & 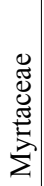 & 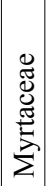 & 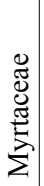 & 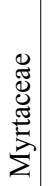 & $\mid$\begin{tabular}{c}
$\mathbb{J}$ \\
$\mathbb{J}$ \\
$\tilde{\Phi}$ \\
\multirow{5}{5}{} \\
$\Sigma$
\end{tabular} & 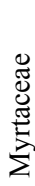 \\
\hline 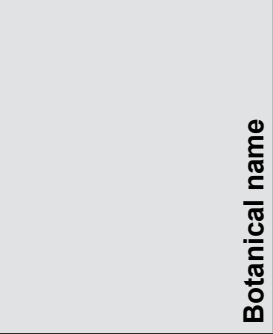 & 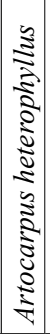 & 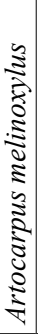 & 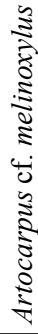 & 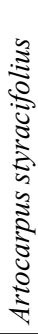 & 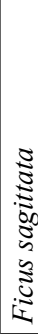 & 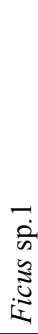 & 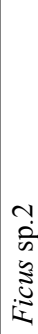 & 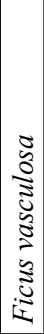 & 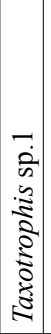 & 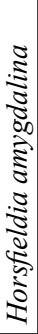 & 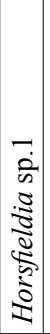 & 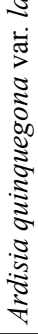 & 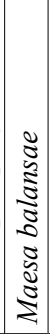 & 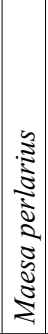 & 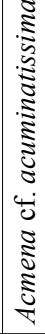 & 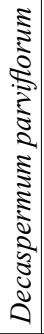 & 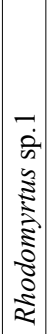 & 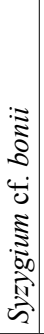 & 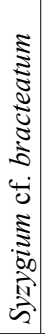 & 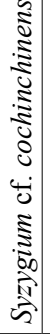 & 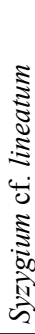 \\
\hline
\end{tabular}




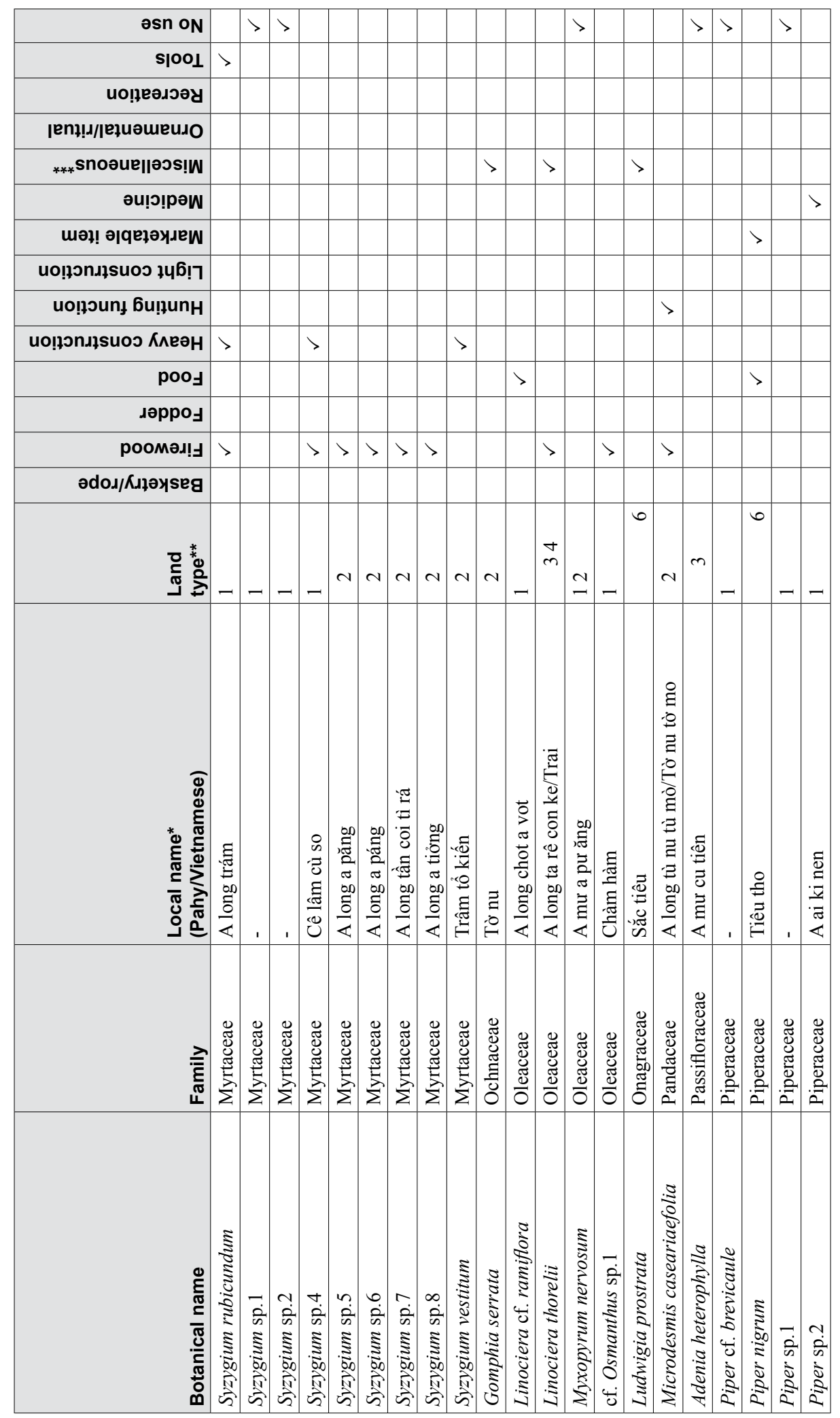




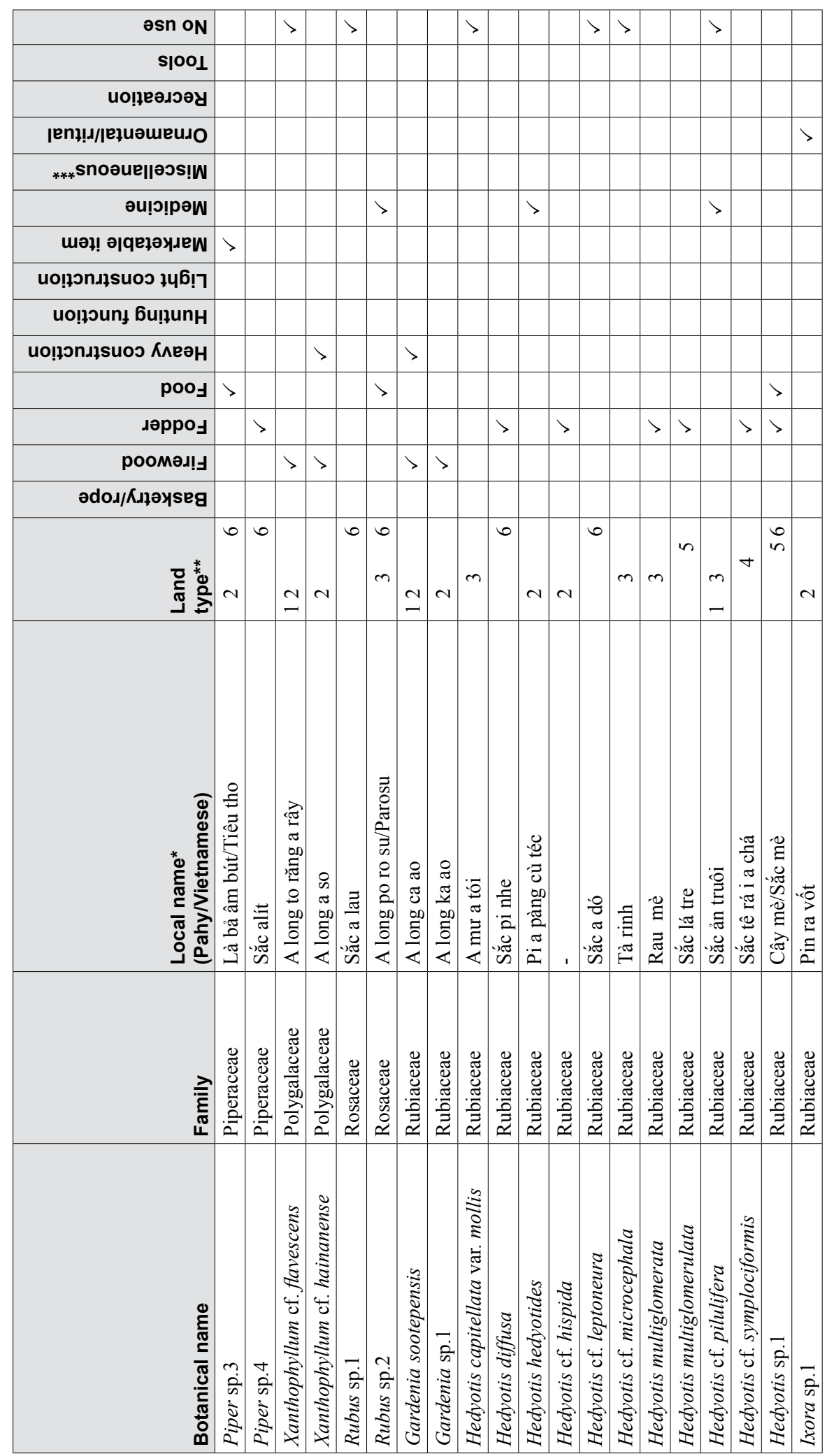




\begin{tabular}{|c|c|c|c|c|c|c|c|c|c|c|c|c|c|c|c|c|c|c|c|}
\hline esn on & $>$ & $>$ & $>$ & $>$ & $>$ & & $>$ & & & & $>$ & $>$ & & & & & $>$ & $>$ & \\
\hline sjool & & & & & & & & & & & & & & & & & & & \\
\hline ио!̣еәдәәу & & & & & & & & & & & & & & & & & & & \\
\hline ןепұ!د/|еұиәшеило & & & & & & & & & & & & & & & & & & & \\
\hline${ }_{* * *}$ snoəue ||әэ! & & & & & & & & & & & & & $>$ & & & & & & \\
\hline әu!ฺ!pəw & & & & & & $>$ & & $>$ & & & $>$ & & & & & & & & \\
\hline шәң! әવqеłәудеW & & & & & & & & & & & & & & & & & & & \\
\hline uo!łonגłsuos & & & & & & & & & & $>$ & & & & & & & & & \\
\hline uo!̣ounł 6u!łunH & & & & & & & & & & & & & & & & & & & \\
\hline 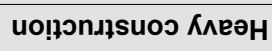 & & & & & & & & & & & & & & & & & & & $>$ \\
\hline poos & & & & & & & $>$ & & & & & & & $>$ & $>$ & $>$ & & & \\
\hline גәрроత & & & & & & & & & & & & & & & & & & & \\
\hline роомәд! & & & & & & & & & $>$ & $>$ & & & & $>$ & $>$ & $>$ & & $>$ & $>$ \\
\hline әdoג/Кıәәуsеg & & & $>$ & & & & & & & & & & & & & & & & \\
\hline 일 & 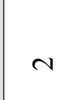 & - & $\stackrel{m}{\sim}$ & + & a & $\hat{n}$ & $\sim$ & $m$ & a & $a$ & & $\mathrm{~N}$ & $a$ & $m$ & $m$ & $\sim$ & $a$ & $\alpha$ & 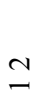 \\
\hline 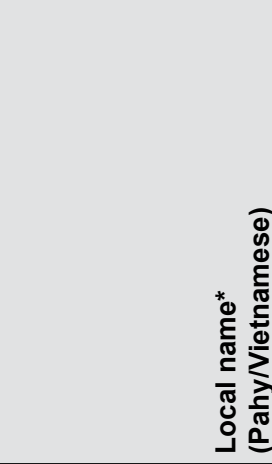 & ' & & 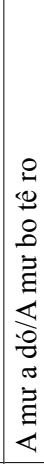 & 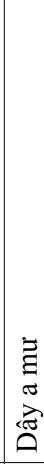 & 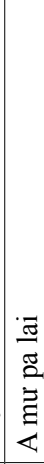 & 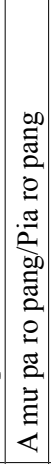 & 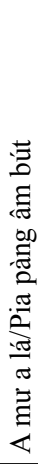 & 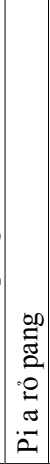 & 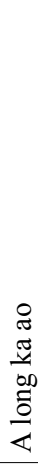 & 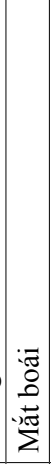 & 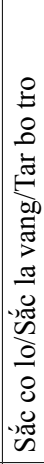 & 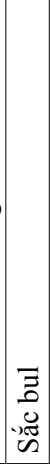 & $\frac{y}{0}$ & 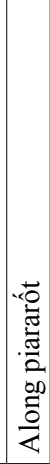 & 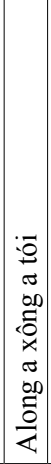 & 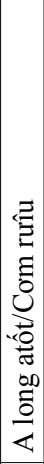 & \begin{tabular}{|c|} 
\\
\\
\\
0 \\
0 \\
0 \\
00 \\
$\frac{0}{2}$ \\
$\frac{1}{4}$ \\
\end{tabular} & 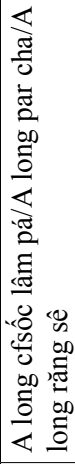 & \\
\hline $\begin{array}{l}\text { 글 } \\
\text { है } \\
\text { एँ }\end{array}$ & 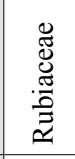 & 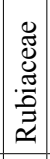 & 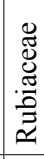 & 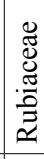 & 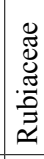 & 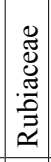 & 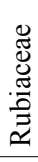 & 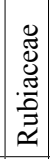 & 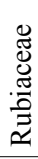 & 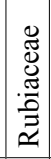 & 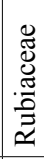 & 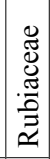 & 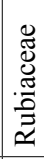 & 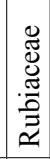 & 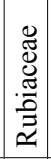 & 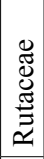 & 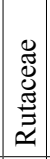 & 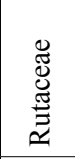 & 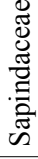 \\
\hline 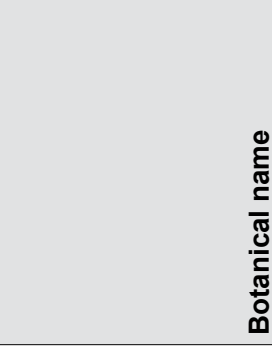 & 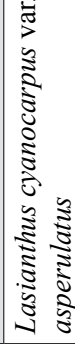 & 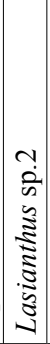 & 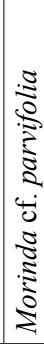 & 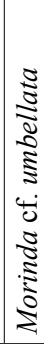 & 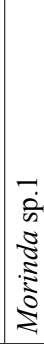 & 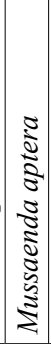 & 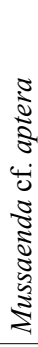 & 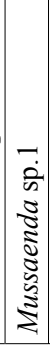 & 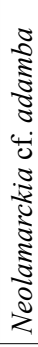 & 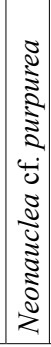 & 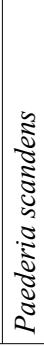 & 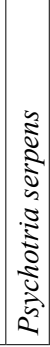 & $\begin{array}{c}-1 \\
0 \\
0 \\
0 \\
0 \\
0 \\
0 \\
0 \\
0 \\
0 \\
2\end{array}$ & 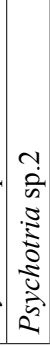 & 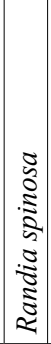 & 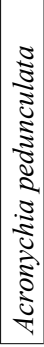 & 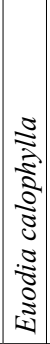 & 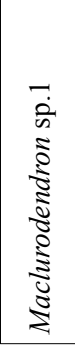 & 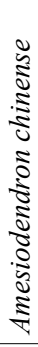 \\
\hline
\end{tabular}




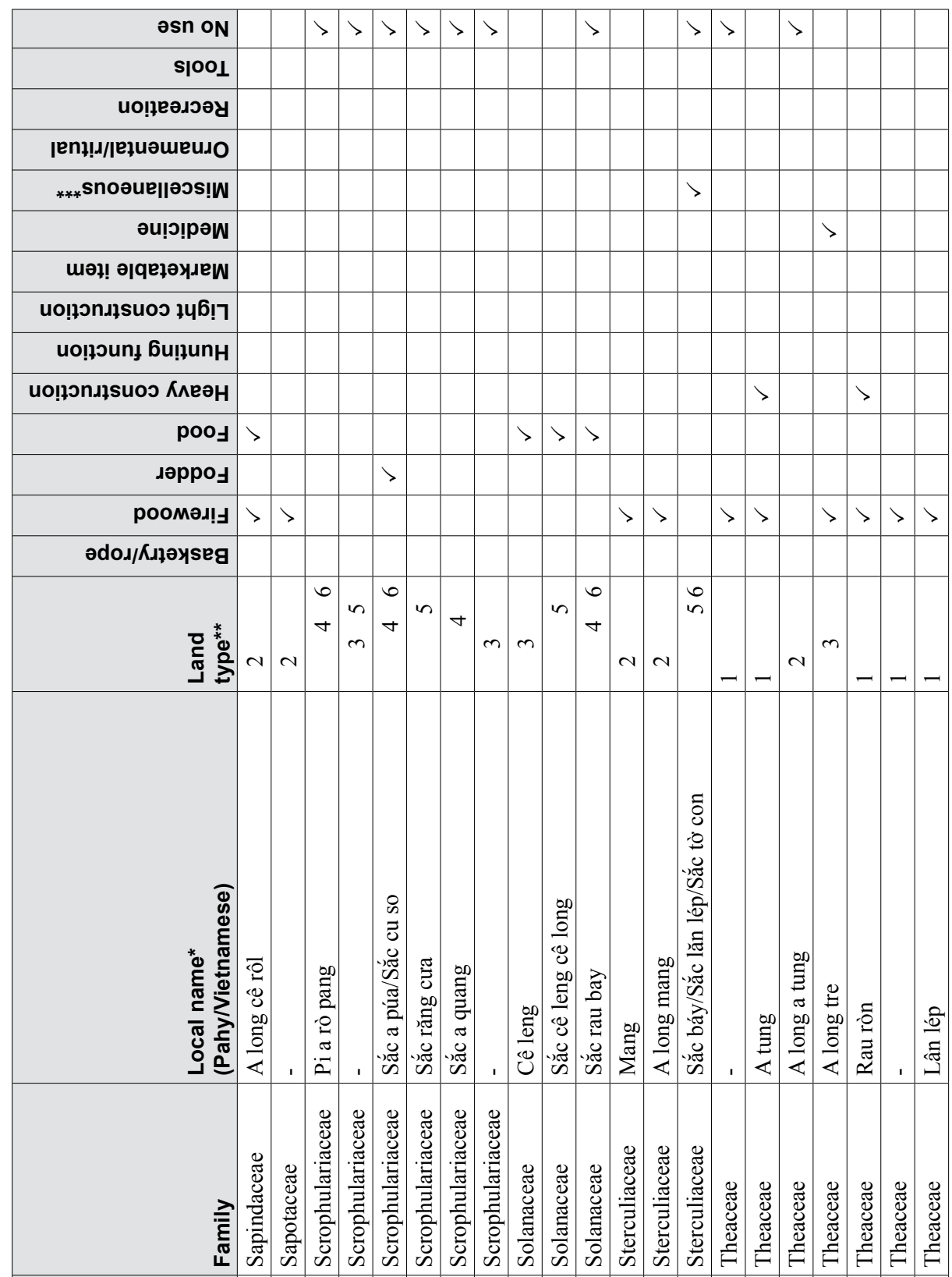

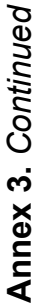

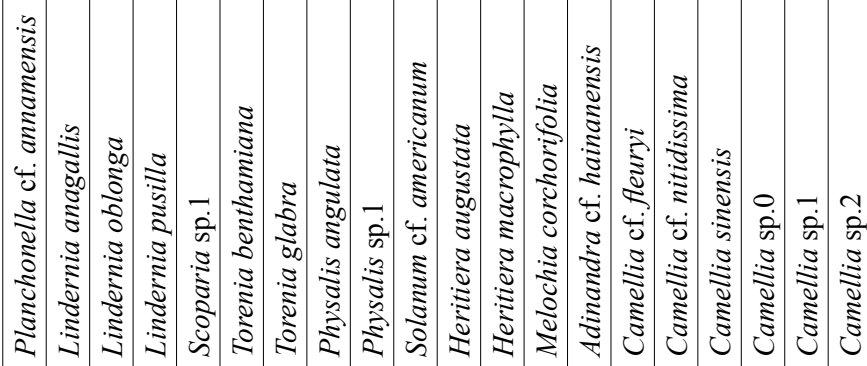




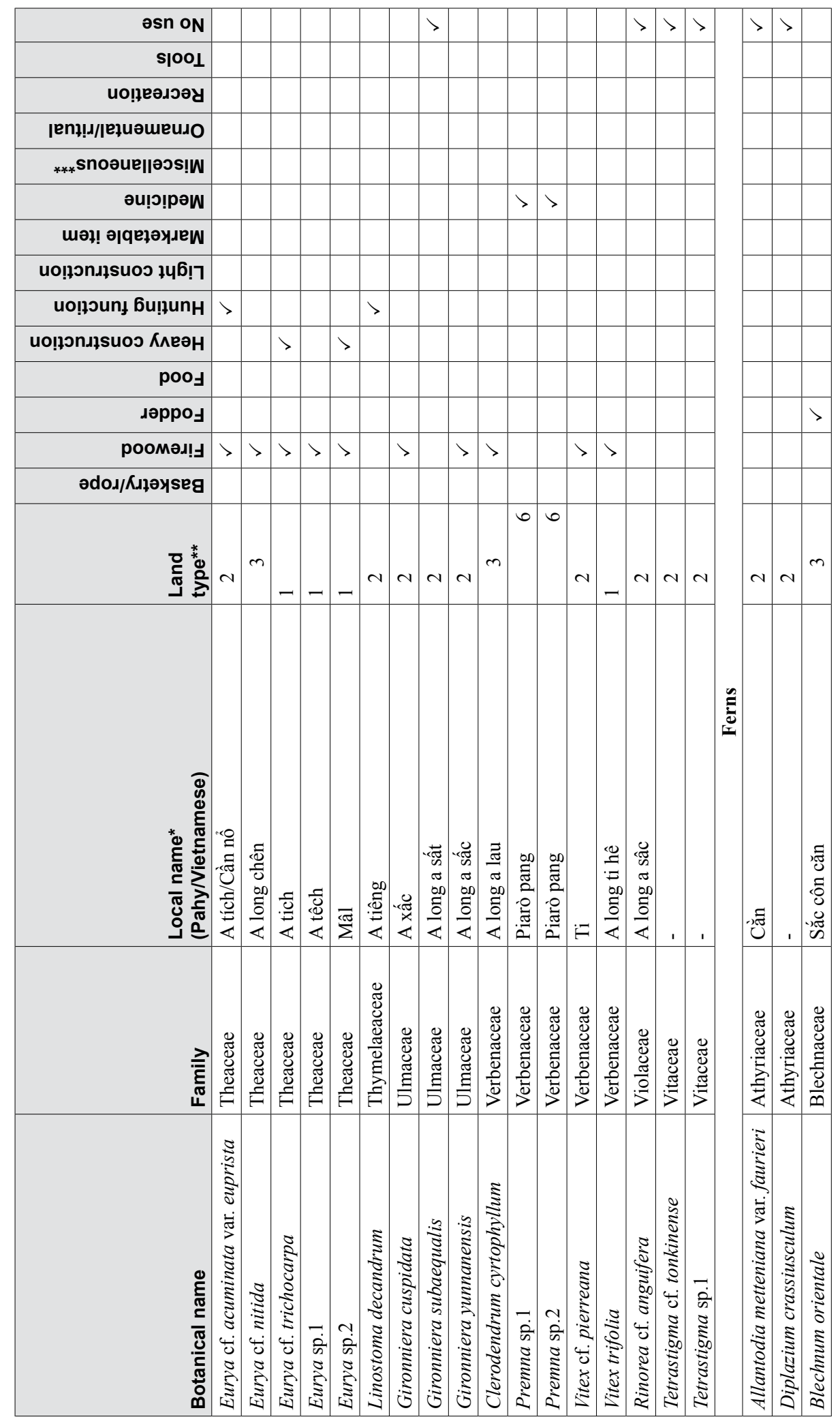




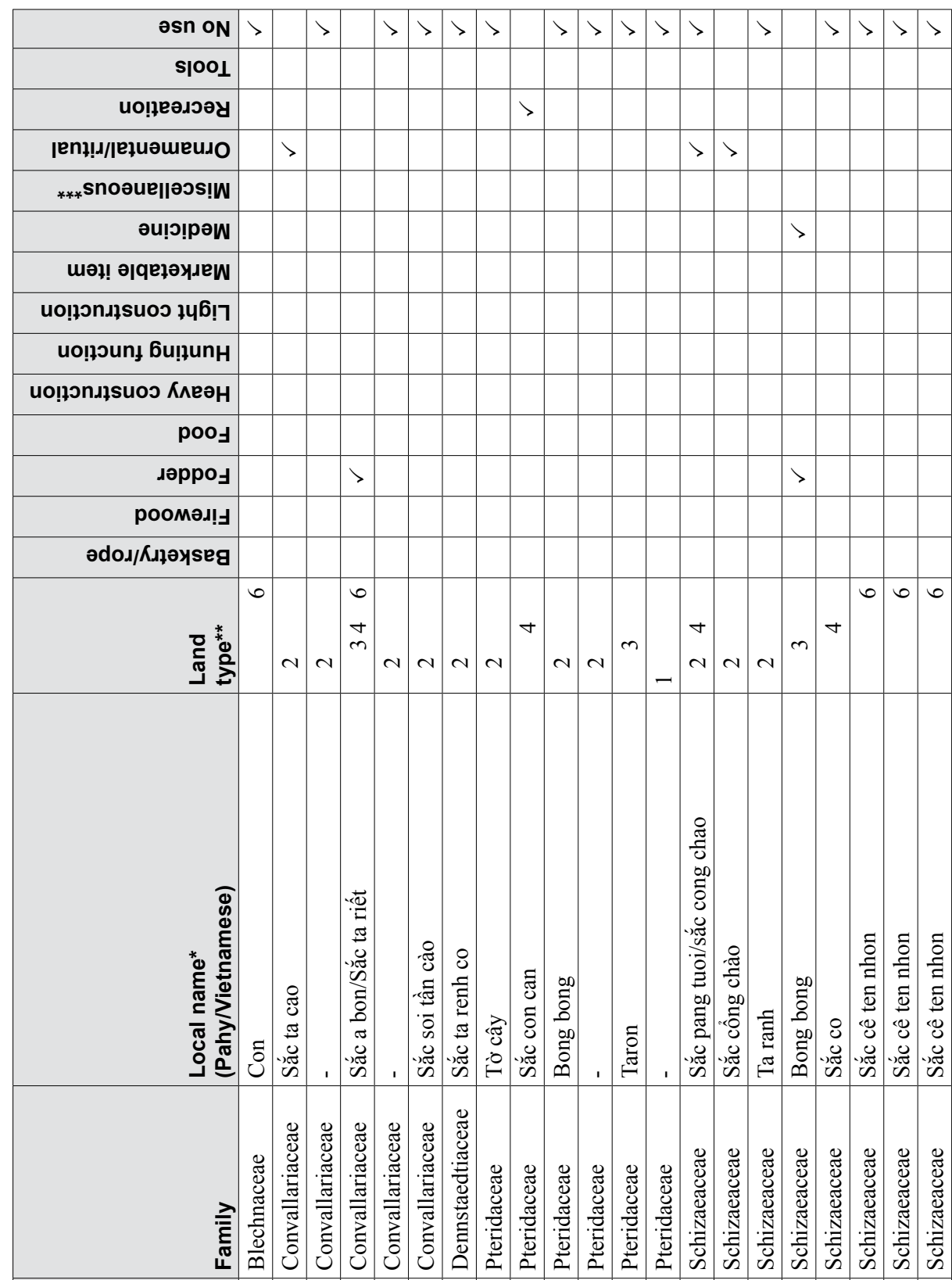

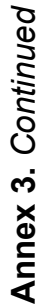

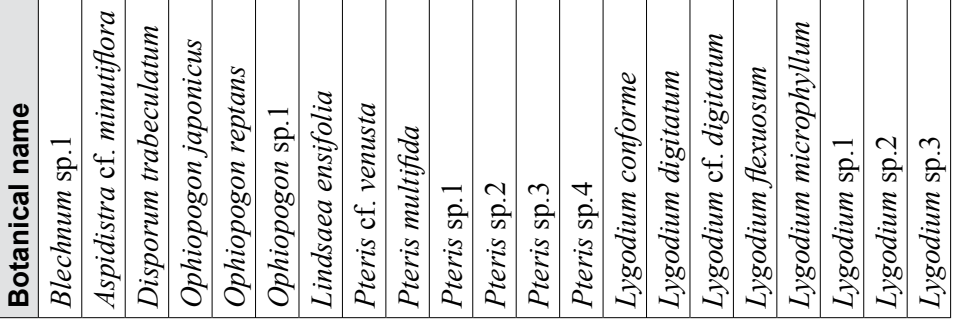




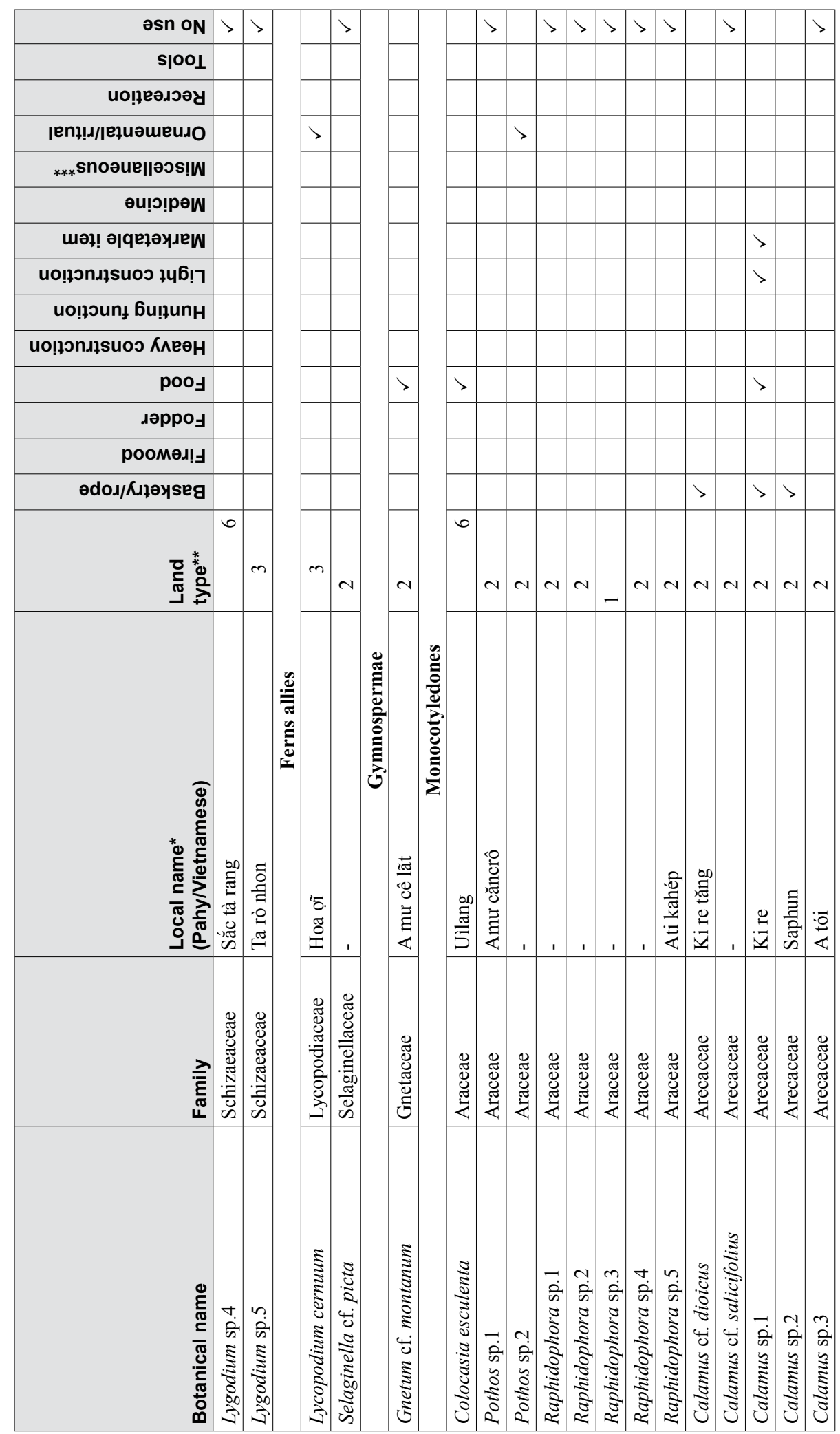




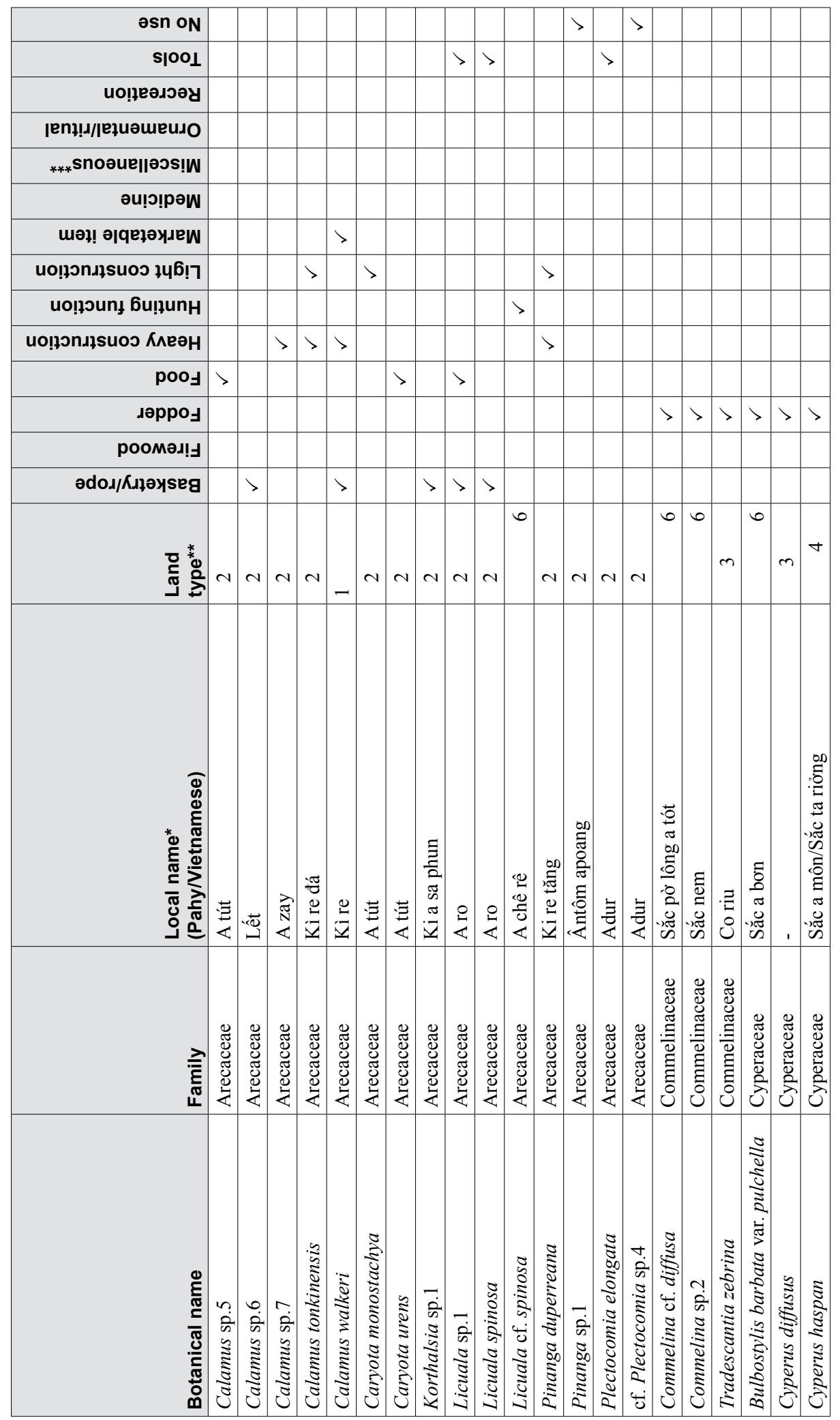




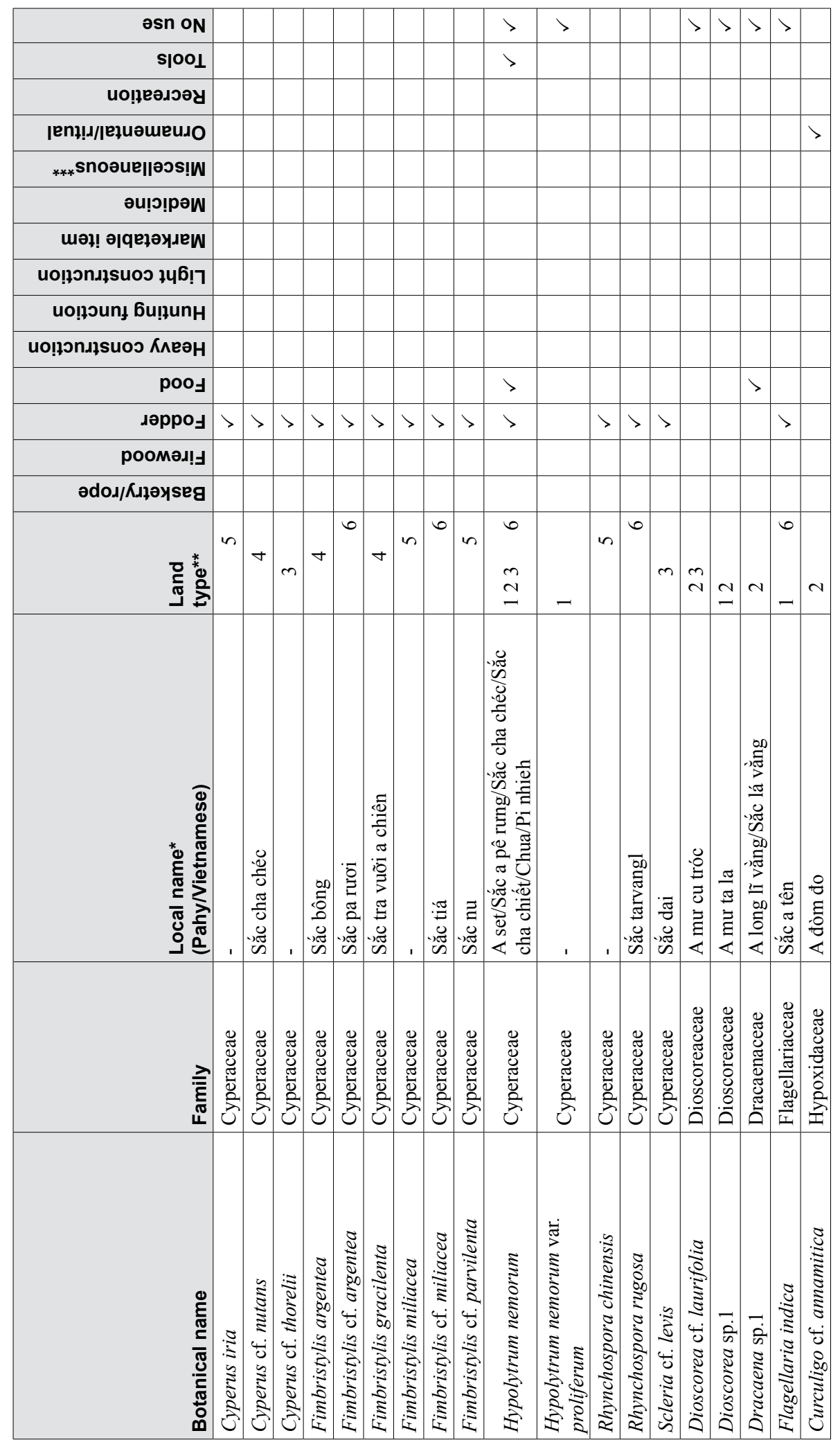




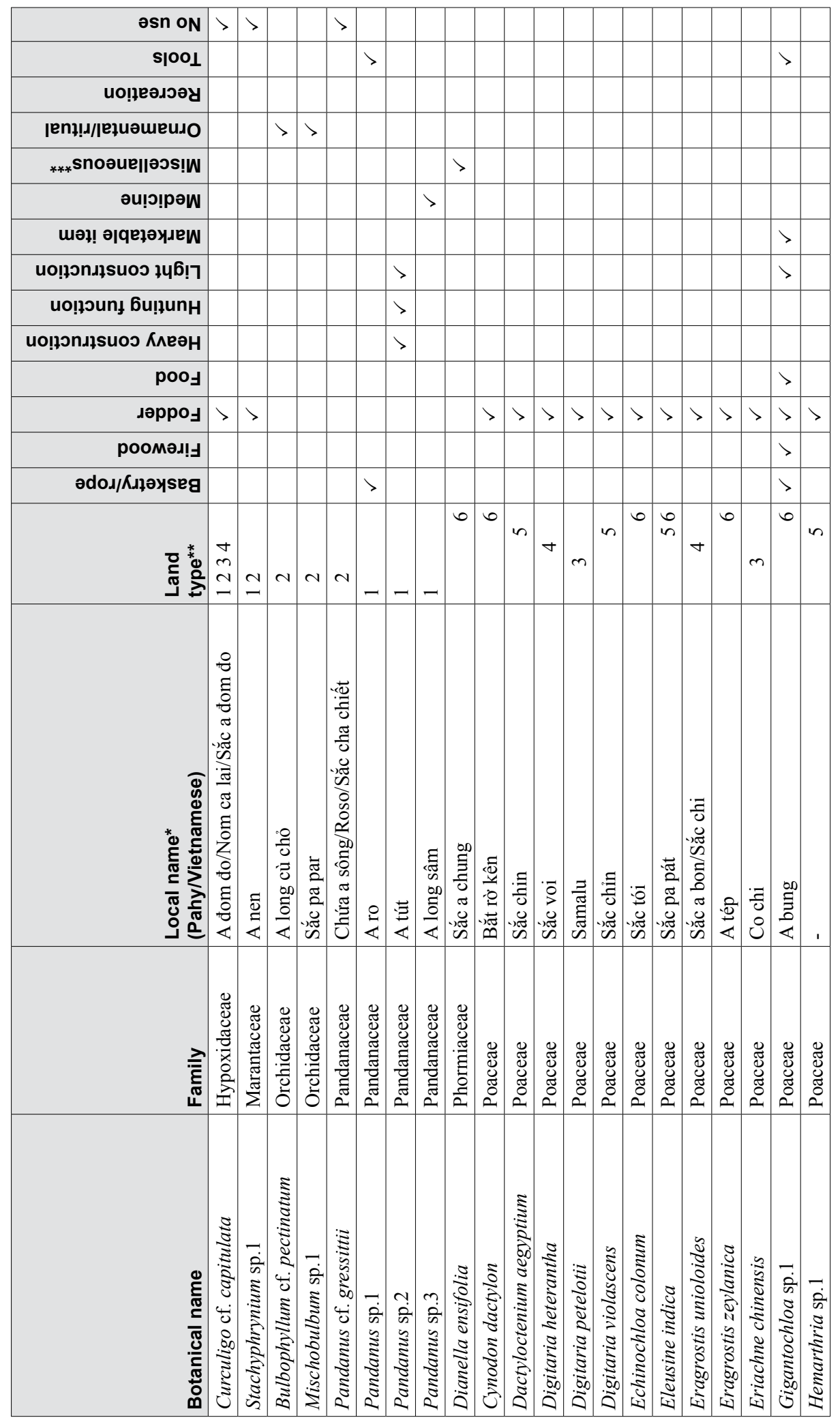




\begin{tabular}{|c|c|c|c|c|c|c|c|c|c|c|c|c|c|c|c|c|c|c|c|c|c|}
\hline esn on & & & & $>$ & & & & & & & & & & & & & & & & & \\
\hline s|ool & & & & & & & & & & & & & & & & & & & & & \\
\hline ио!реәдәәу & & & & & & & & & & & & & & & & & & & & & \\
\hline ןепұ!ג/|ејиәшеихо & & & & & & & & & & & & & & & & & & & & & \\
\hline${ }_{* * *}$ snoəue ||әэ! & & & & & & & & & & & & & & & & & & & & & \\
\hline әи!ฺ!рәW & $>$ & & & & & & & & & & & & & & & & & & & & \\
\hline шәң! әрqеұәудеW & & & & & & & & & & & & & & & & & & & & & \\
\hline uo!łonגłsuos & & & & & & & & & & & & & & & & & & & & & \\
\hline uo!̣’unf 6u!̣unH & & & & & & & & & & & & & & & & & & & & & \\
\hline ио!̣วnдұsuoว КАеәН & $>$ & & & & & & & & & & & & & & & & & $>$ & & $>$ & $>$ \\
\hline poos & $>$ & & & & $>$ & & & & & & & & & & & & & & & $>$ & \\
\hline גәрpo & $>$ & $>$ & $>$ & & & $>$ & $>$ & $>$ & $>$ & $>$ & $>$ & $>$ & $>$ & $>$ & $>$ & $>$ & $>$ & $>$ & $>$ & & \\
\hline роомәџ! & & & & & & & & & & & & & & & & & & & & $>$ & \\
\hline әdoג/Кıłәуseg & & & & & & & & & & & & & & & & & & & & $>$ & \\
\hline 일 & $\stackrel{+}{m}$ & $\stackrel{m}{m}$ & 0 & $m$ & n & in & $m$ & $\nabla$ & 0 & v & $m$ & $\begin{array}{l}0 \\
\sim \\
7\end{array}$ & 0 & 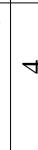 & m & cr & $m$ & $\begin{array}{l}0 \\
\dot{\sigma} \\
m\end{array}$ & $\begin{array}{l}0 \\
+\end{array}$ & 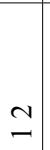 & \\
\hline 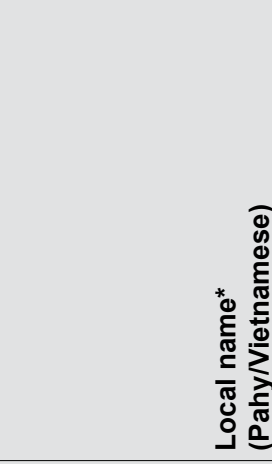 & 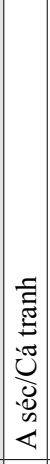 & 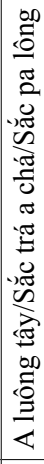 & . & 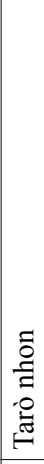 & $\frac{\pi}{4}$ & ' & I & 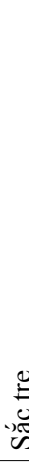 & 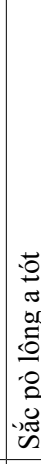 & 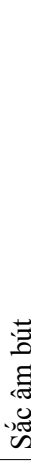 & .0ิ & 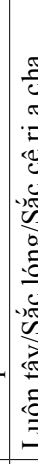 & . & 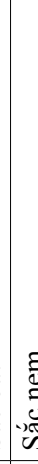 & & $\mathscr{y}$ & 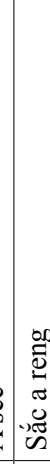 & 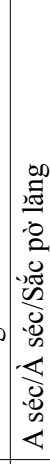 & 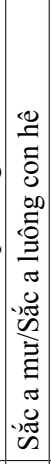 & 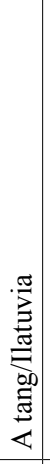 & $\mid$ \\
\hline 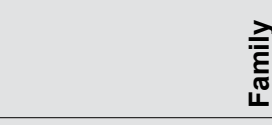 & $\begin{array}{l}\mathscr{q} \\
\mathbb{J} \\
\tilde{U} \\
\tilde{D} \\
2 \\
2\end{array}$ & $\begin{array}{l}\mathscr{J} \\
\mathbb{J} \\
\tilde{J} \\
\tilde{D} \\
2\end{array}$ & 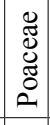 & 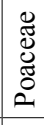 & 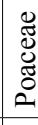 & 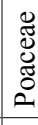 & 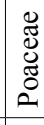 & 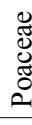 & 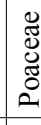 & $\begin{array}{l}\mathscr{J} \\
\mathbb{J} \\
\tilde{J} \\
0\end{array}$ & $\begin{array}{l}\mathscr{\Xi} \\
\mathbb{\Xi} \\
\tilde{\Xi} \\
\stackrel{0}{0}\end{array}$ & 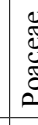 & $\begin{array}{l}\mathscr{\Xi} \\
\tilde{\Xi} \\
\tilde{\Xi} \\
\stackrel{0}{0}\end{array}$ & 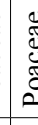 & 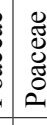 & 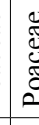 & 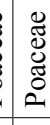 & 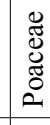 & \begin{tabular}{|c|}
$\mathscr{J}$ \\
$\mathbb{J}$ \\
$\tilde{U}$ \\
$\tilde{D}$ \\
2 \\
\end{tabular} & 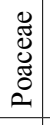 & 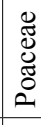 \\
\hline 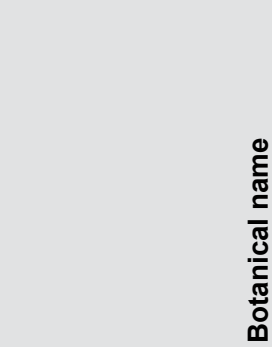 & 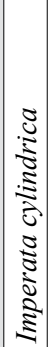 & 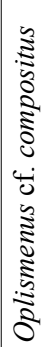 & 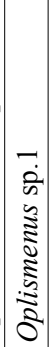 & 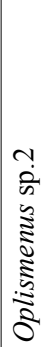 & 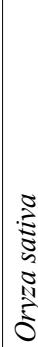 & 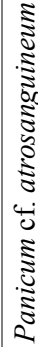 & 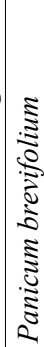 & 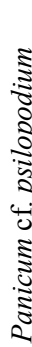 & 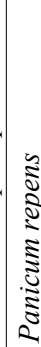 & 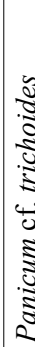 & 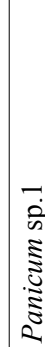 & 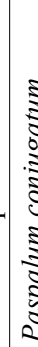 & 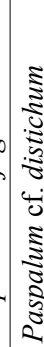 & 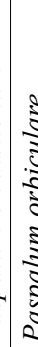 & 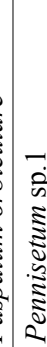 & 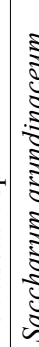 & 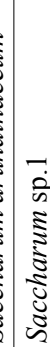 & 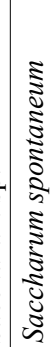 & 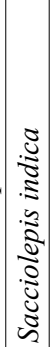 & 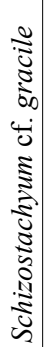 & 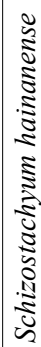 \\
\hline
\end{tabular}




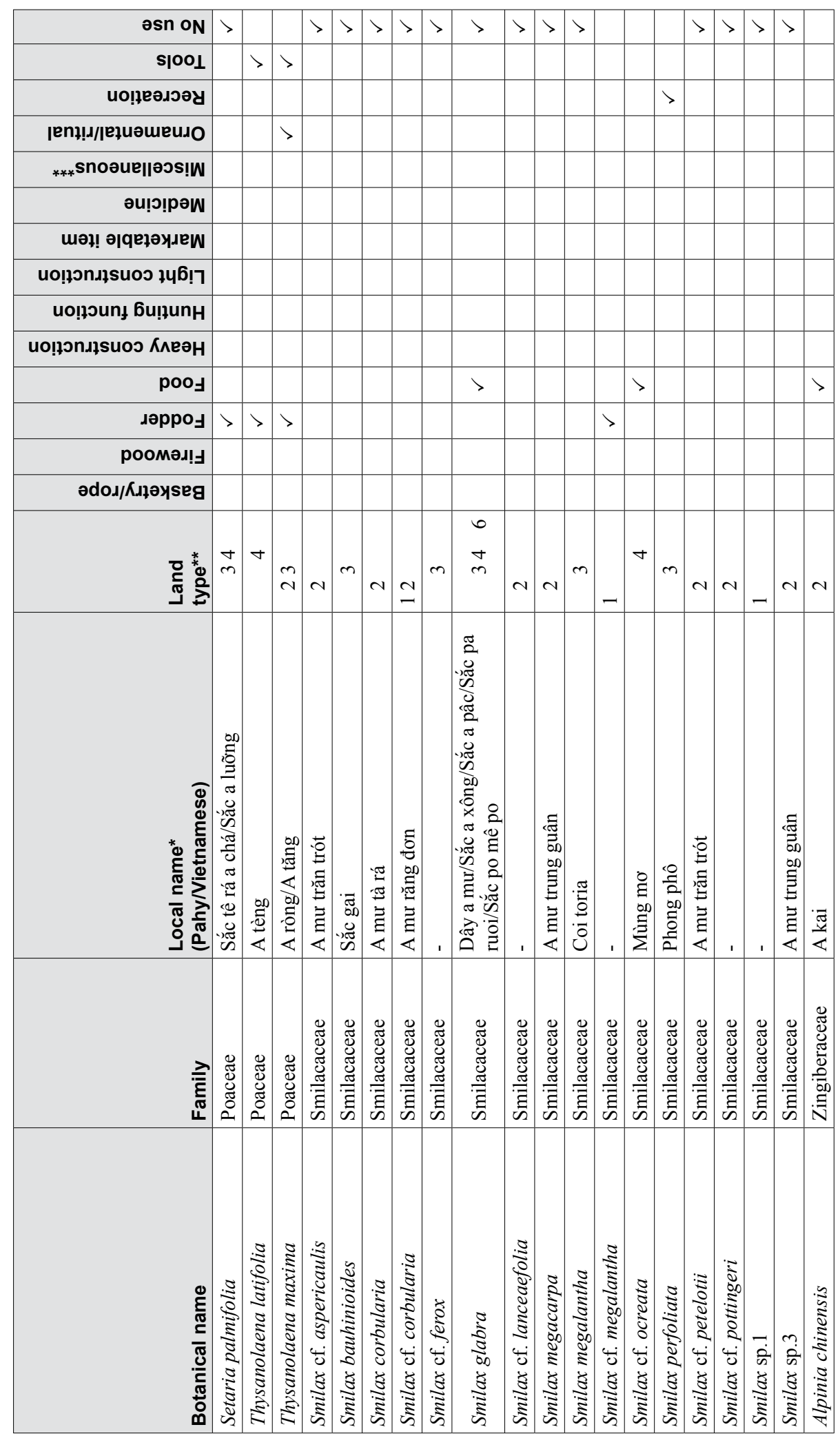




\begin{tabular}{|c|c|c|c|c|c|c|c|c|c|c|c|c|c|c|c|c|c|c|c|c|c|}
\hline əsn on & & $>$ & & $>$ & & & & & & & & $>$ & $>$ & & & & $>$ & & & & \\
\hline s|ool & & & & & & & & & & & & & & & & & & & & & \\
\hline ио!̣еәдәәу & & & & & & & & & & & & & & & & & & & & & \\
\hline ןеnұ!د/|еұиәшеuدо & $>$ & $>$ & & & & & & & & & & & & & & & & & & & \\
\hline${ }_{* * *}$ snoəue ||әэ! & & & & & & & & & & $>$ & & & & & & & & $>$ & & & \\
\hline әи!ฺ!рәพ & & & & & & & & & & & & & & & & & & & $>$ & & \\
\hline шәң! әવqеłәудеW & & & & & & & & & & & & & & & & & & & $>$ & & \\
\hline uo!łonגłsuos & & & & & & & & & & & & & & & & & & & & & \\
\hline uo!łounł 6u!łunH & & & & & & & & & & & & & & & & & & & & & \\
\hline 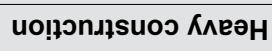 & & & & & & & & & $>$ & & & & & $>$ & & & & $>$ & & & \\
\hline poos & $>$ & $>$ & $>$ & & $>$ & & & $>$ & & & & & & & & & & $>$ & $>$ & & \\
\hline גәрpоత & & & & & & & $>$ & & & & & & & & & & & & & & \\
\hline роомәд! & & & & & & & & & $>$ & & $>$ & & & $>$ & $>$ & $>$ & & & $>$ & $>$ & $>$ \\
\hline әdoג/Кıәәуseg & & & & & & & & & & & & & & & & & & & & & \\
\hline ᄅْ & $N$ & $\begin{array}{l}+ \\
\sim \\
\sim \\
-\end{array}$ & 6 & $N$ & - & $\ddot{g}$ & in & $\nabla$ & $\theta$ & - & 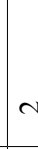 & - & $\theta$ & - & $\theta$ & 0 & 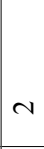 & 0 & $m$ & 0 & 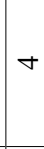 \\
\hline 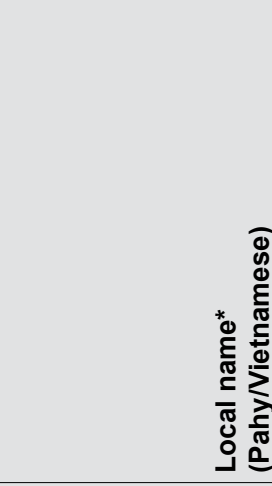 & 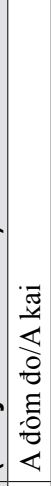 & 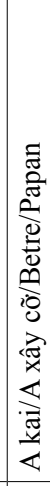 & 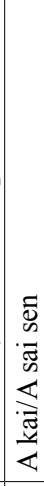 & 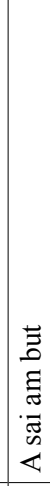 & : & 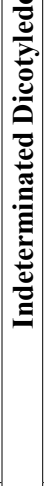 & 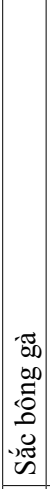 & 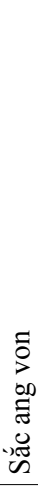 & $\stackrel{\ominus}{\frac{\otimes}{4}}$ & $\begin{array}{l}\text { 咅 } \\
\text { 䍐 }\end{array}$ & 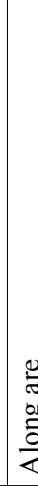 & & 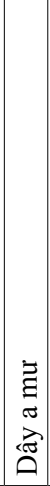 & $\overrightarrow{\bar{\sigma}}$ & 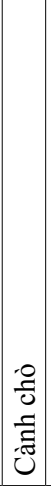 & 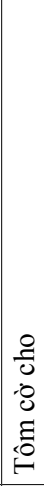 & , & 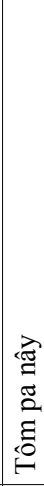 & $\frac{\Xi}{0}$ & 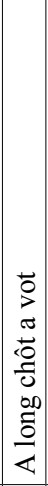 & $\begin{array}{l} \\
0 \\
0 \\
0 \\
\infty \\
< \\
<\end{array}$ \\
\hline 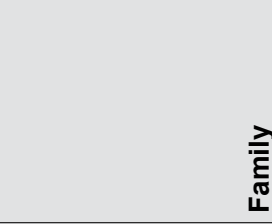 & 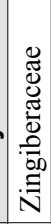 & 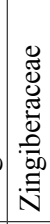 & 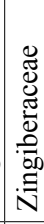 & 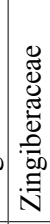 & 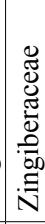 & & 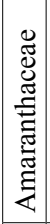 & 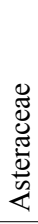 & 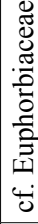 & 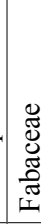 & 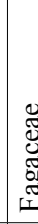 & 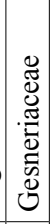 & 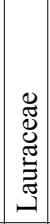 & 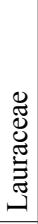 & 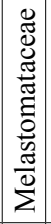 & 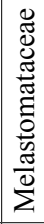 & 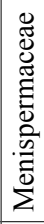 & 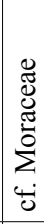 & 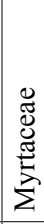 & 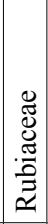 & 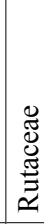 \\
\hline 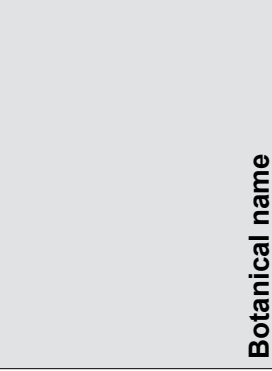 & 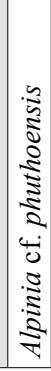 & 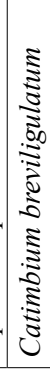 & 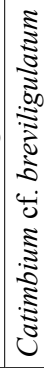 & 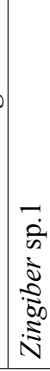 & 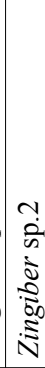 & & 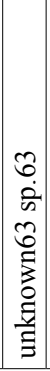 & 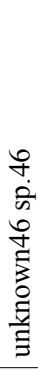 & 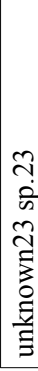 & 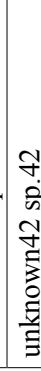 & 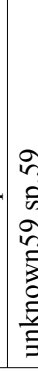 & 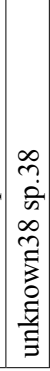 & 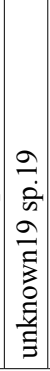 & 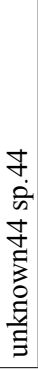 & 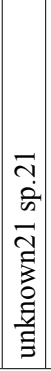 & 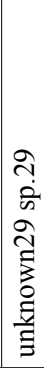 & 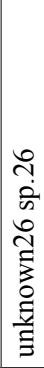 & 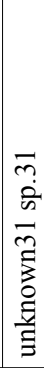 & 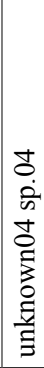 & 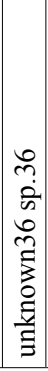 & 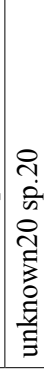 \\
\hline
\end{tabular}




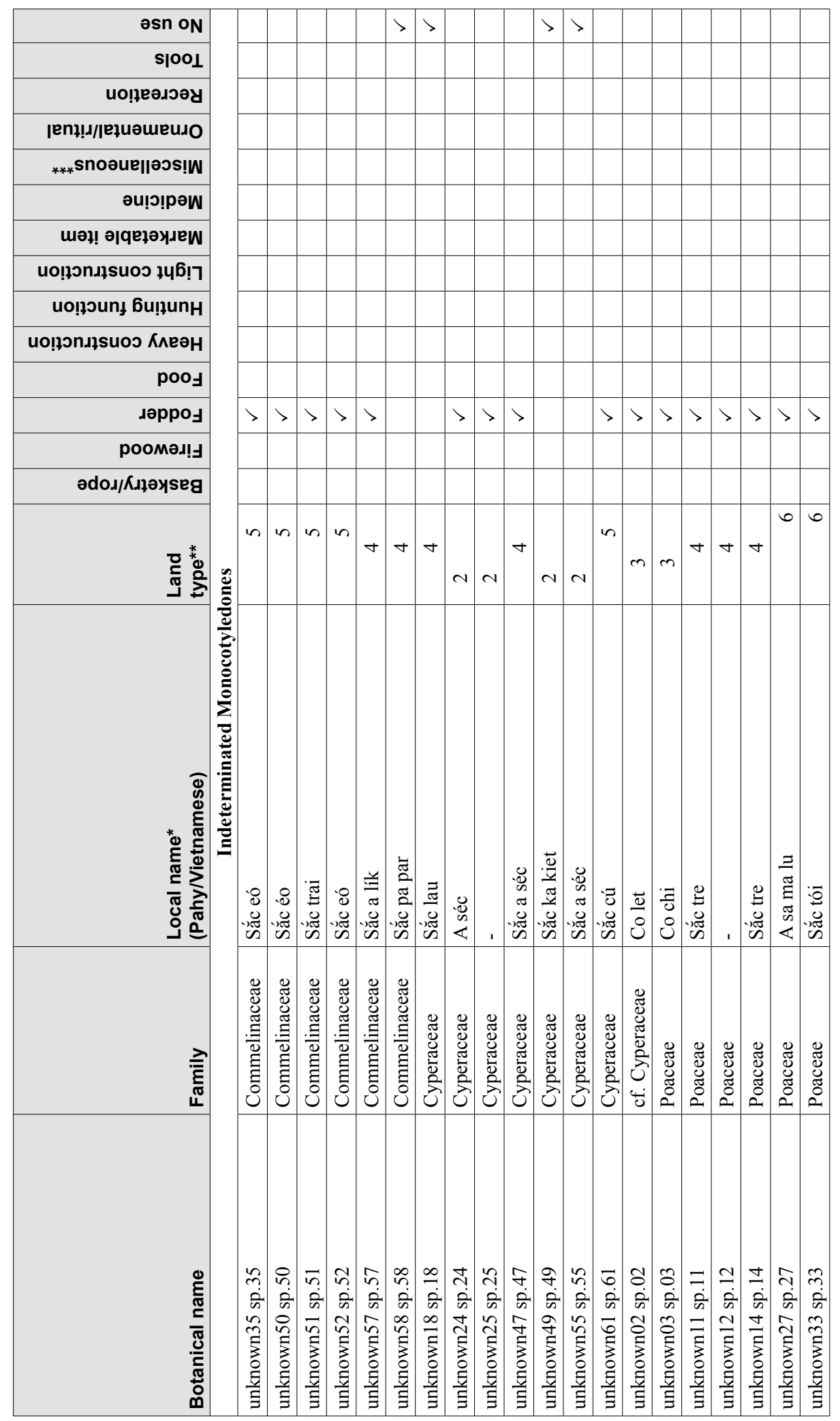




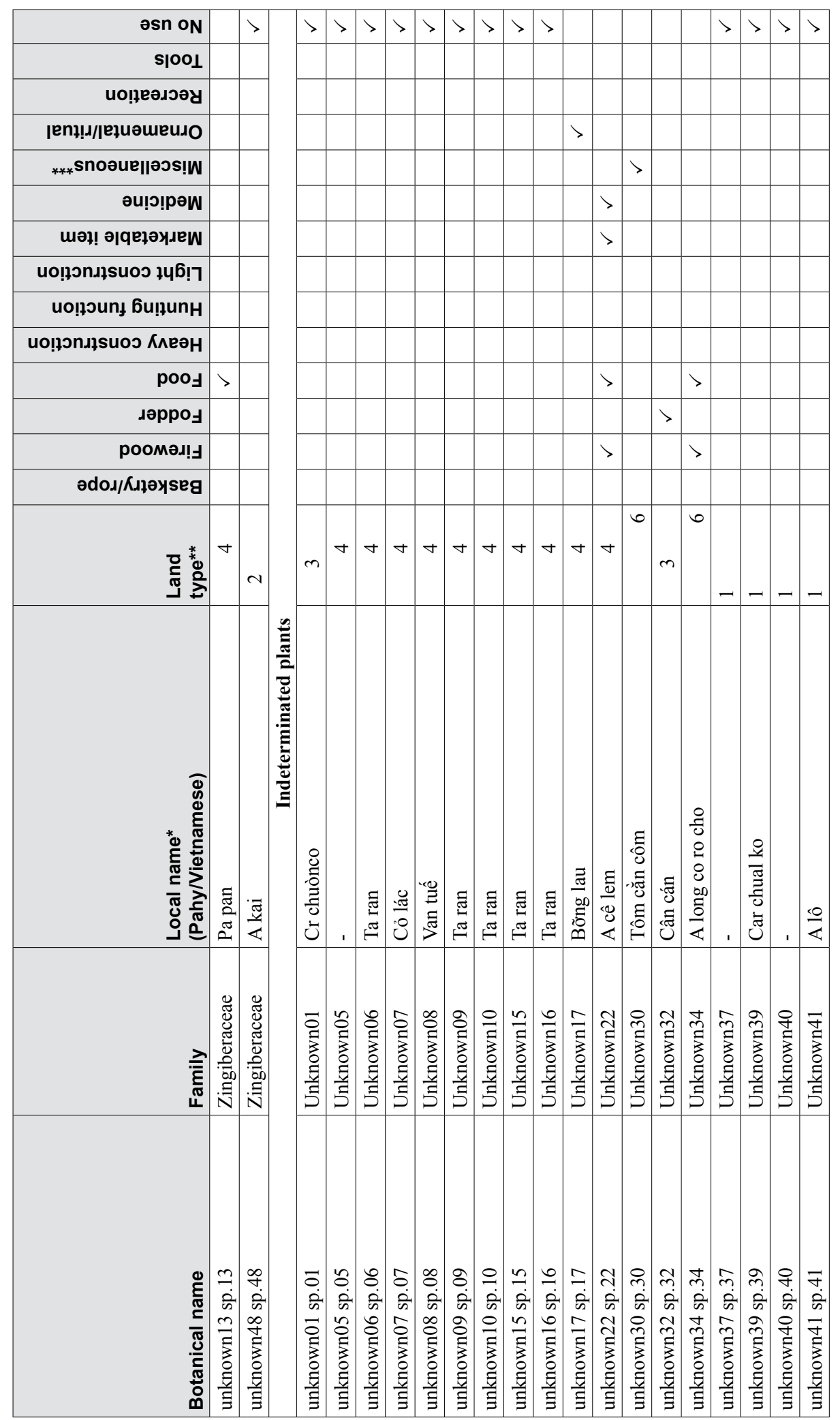




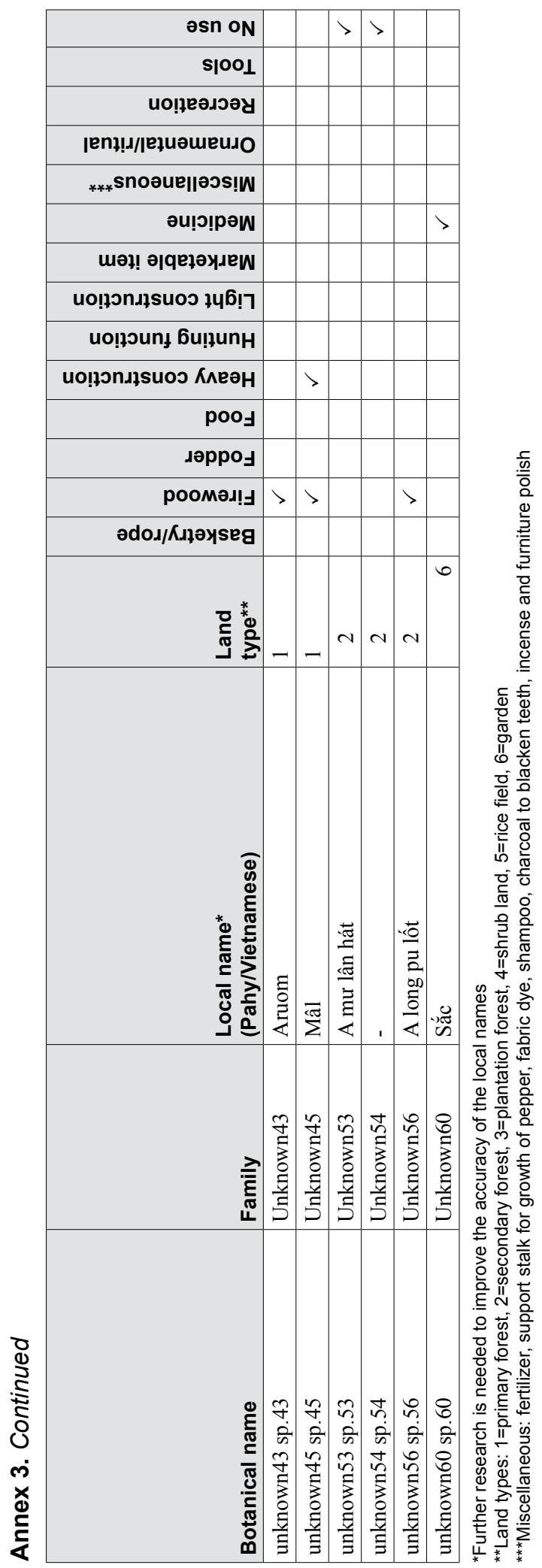


The Center for International Forestry Research (CIFOR) is a leading international forestry research organization established in 1993 in response to global concerns about the social, environmental, and economic consequences of forest loss and degradation. CIFOR is dedicated to developing policies and technologies for sustainable use and management of forests, and for enhancing the well-being of people in developing countries who rely on tropical forests for their livelihoods. CIFOR is one of the 15 Future Harvest centres of the Consultative Group on International Agricultural Research (CGIAR). With headquarters in Bogor, Indonesia, CIFOR has regional offices in Brazil, Burkina Faso, Cameroon and Zimbabwe, and it works in over 30 other countries around the world.

\section{Donors}

The Center for International Forestry Research (CIFOR) receives its major funding from governments, international development organizations, private foundations and regional organizations. In 2005, CIFOR received financial support from Australia, Asian Development Bank (ADB), Belgium, Brazil, Canada, China, Centre de coopération internationale en recherche agronomique pour le développement (CIRAD), Cordaid, Conservation International Foundation (CIF), European Commission, Finland, Food and Agriculture Organization of the United Nations (FAO), Ford Foundation, France, German Agency for Technical Cooperation (GTZ), German Federal Ministry for Economic Cooperation and Development (BMZ), Indonesia, International Development Research Centre (IDRC), International Fund for Agricultural Development (IFAD), International Tropical Timber Organization (ITTO), Israel, Italy, The World Conservation Union (IUCN), Japan, Korea, Netherlands, Norway, Netherlands Development Organization, Overseas Development Institute (ODI), Peruvian Secretariat for International Cooperation (RSCl), Philippines, Spain, Sweden, Swedish University of Agricultural Sciences (SLU), Switzerland, Swiss Agency for the Environment, Forests and Landscape, The Overbrook Foundation, The Nature Conservancy (TNC), Tropical Forest Foundation, Tropenbos International, United States, United Kingdom, United Nations Environment Programme (UNEP), World Bank, World Resources Institute (WRI) and World Wide Fund for Nature (WWF). 
Decisions on land use in Vietnam are often only based on biophysical and economical assessments, with little consideration for the local people's opinions or perspectives. This can lead to conflicts over natural resources management, unsustainable land use and decisions that are unfair to local people. In the landscape surrounding Khe Tran, a village in Central Vietnam lives a Pahy minority group. The driving force in this area has been different land use policies, resulting mainly from a government 'top down' approach, and the consequent changes in local forest status.

The major activities for local livelihoods have shifted from swidden agriculture and high dependency on natural forests, to more sedentary activities. Khe Tran is now situated in the buffer zone of a planned nature reserve and the government has encouraged the villagers to plant economic crops in the bare hills around the village. The people's dependence on forest resources has significantly decreased, and most of the local knowledge about natural forests may soon be lost. The main land covers around the village are now Acacia and rubber plantations, bare lands, and lands for agriculture.

Local knowledge and perspectives are rarely taken into account by state institutions when implementing land allocation projects or making decisions on natural resource management and land use at the landscape level. There is opportunity to better inform development agencies and involve local level stakeholders so that more sustainable decisions can be made. This book reports on what Khe Tran villagers find important in terms of environmental services and resources in their landscape. Our approach integrates multidisciplinary activities - through human and natural sciences- and explains the relative importance of landscape components, products and species for local people. It aims to better articulate local people's priorities for the future, their hopes and values as well as their relationship with the conservation area.
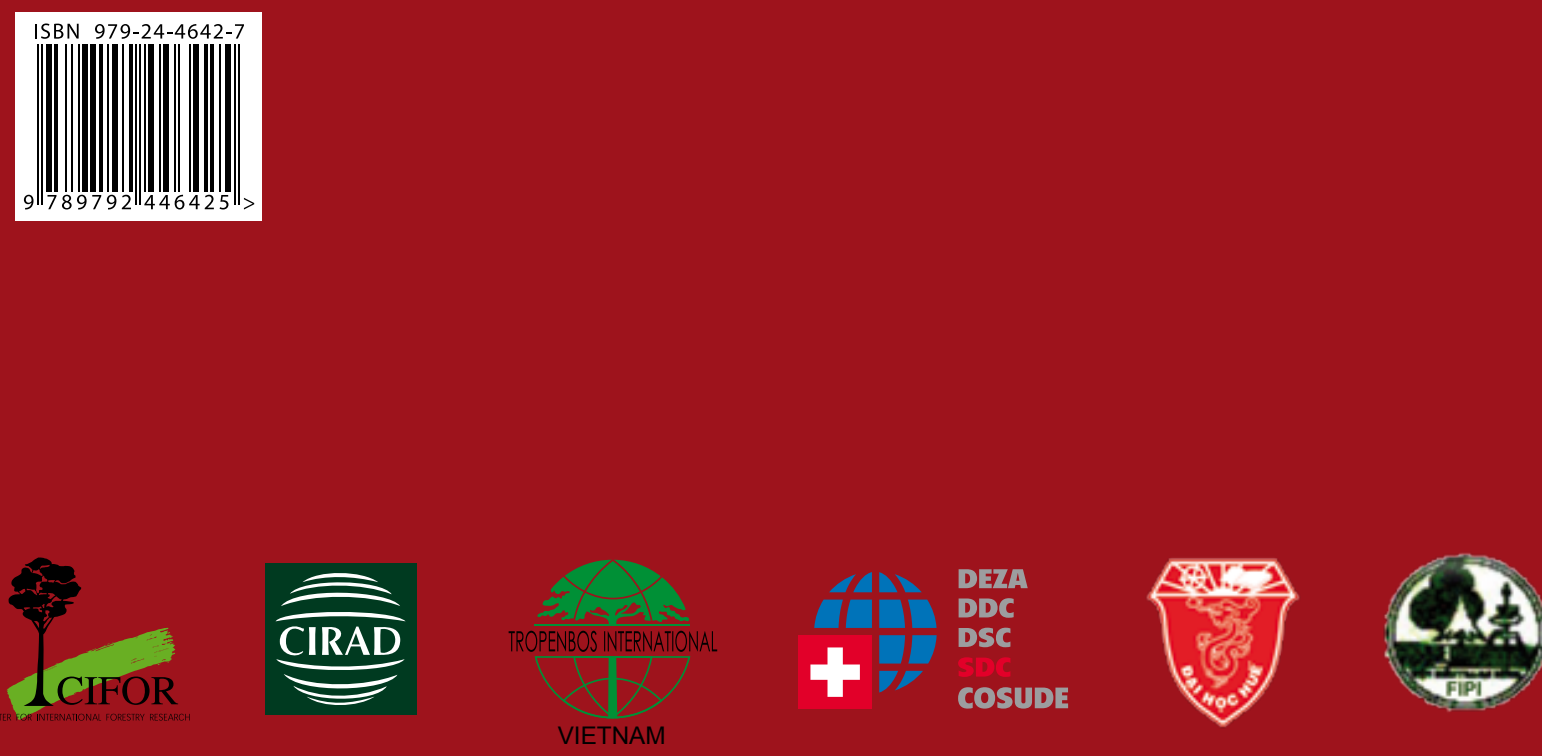